Document downloaded from:

http://hdl.handle.net/10251/71621

This paper must be cited as:

Belhocine, T.; Forsyth, SA.; Gunaratne, HQN.; Nieuwenhuyzen, M.; Nockemann, P.; Vaca Puga, A.; Seddon, KR.... (2015). 3-Methylpiperidinium ionic liquids. Physical Chemistry Chemical Physics. 17(16):10398-10416. doi:10.1039/C4CP05936K

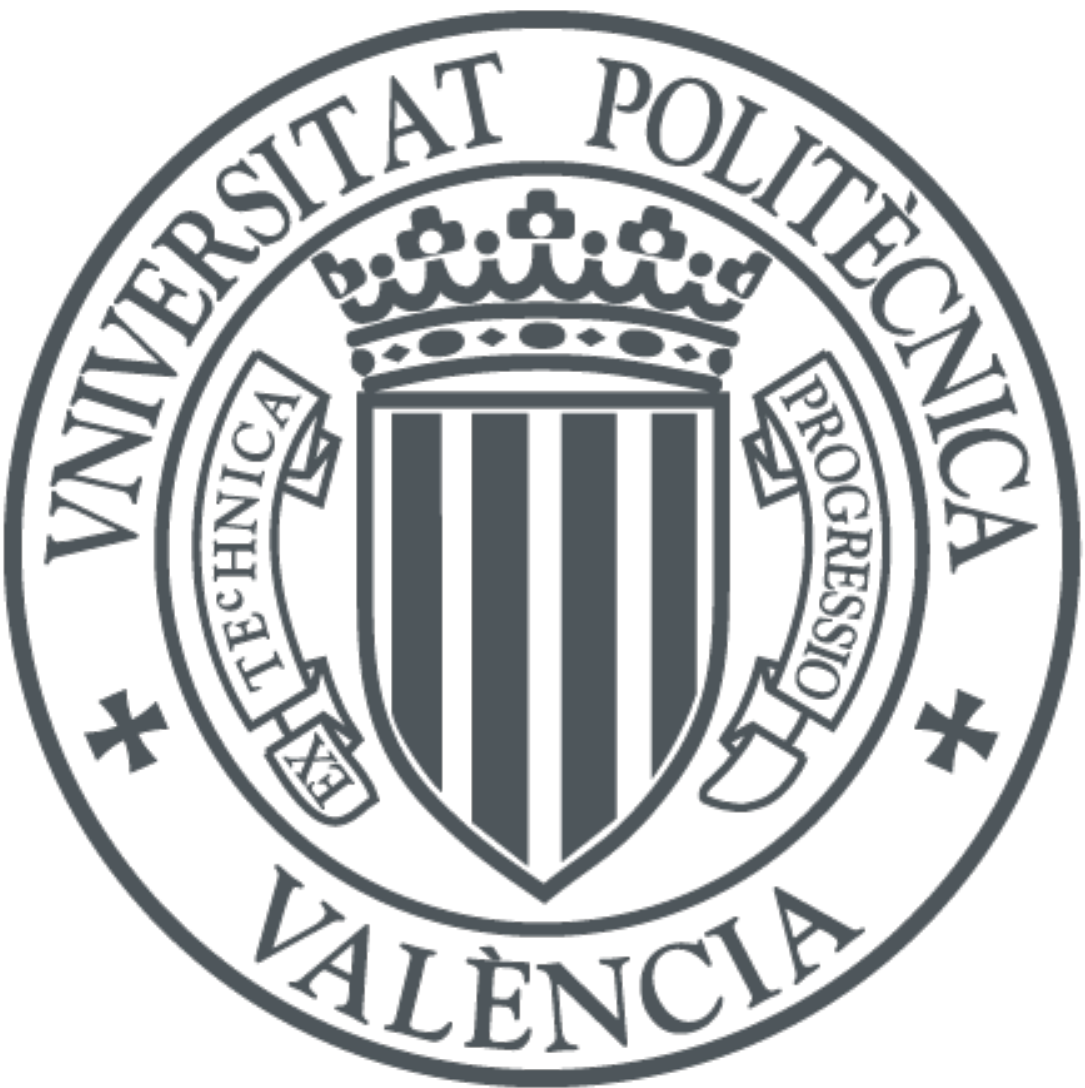

The final publication is available at

http://dx.doi.org/10.1039/c4cp05936k

Copyright Royal Society of Chemistry

Additional Information 


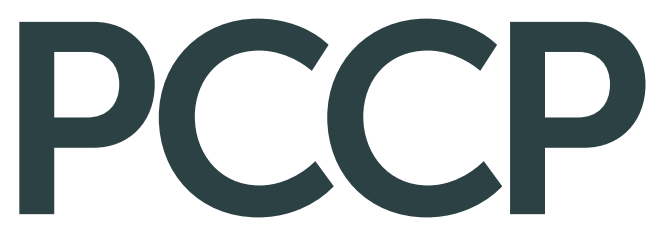

Accepted Manuscript

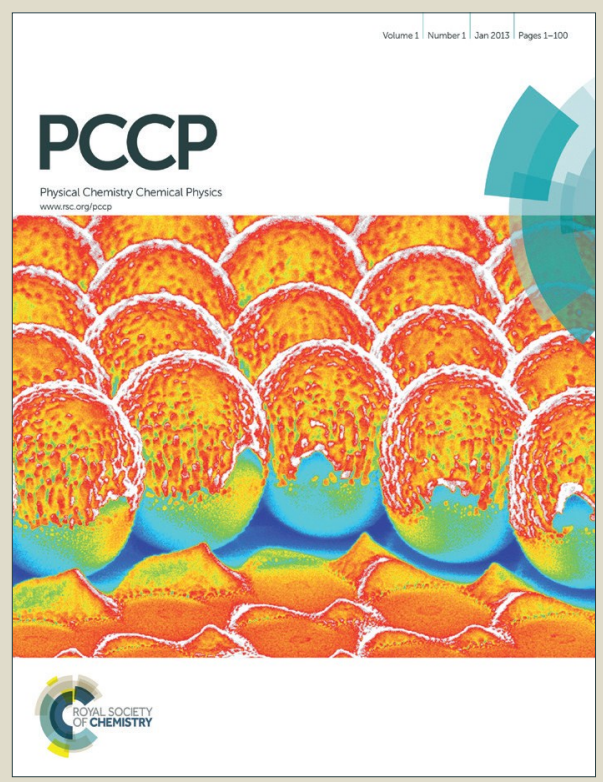

This is an Accepted Manuscript, which has been through the Royal Society of Chemistry peer review process and has been accepted for publication.

Accepted Manuscripts are published online shortly after acceptance, before technical editing, formatting and proof reading. Using this free service, authors can make their results available to the community, in citable form, before we publish the edited article. We will replace this Accepted Manuscript with the edited and formatted Advance Article as soon as it is available.

You can find more information about Accepted Manuscripts in the Information for Authors.

Please note that technical editing may introduce minor changes to the text and/or graphics, which may alter content. The journal's standard Terms \& Conditions and the Ethical guidelines still apply. In no event shall the Royal Society of Chemistry be held responsible for any errors or omissions in this Accepted Manuscript or any consequences arising from the use of any information it contains. 


\title{
3-Methylpiperidinium ionic liquids
}

\author{
Tayeb Belhocine, ${ }^{a}$ Stewart A. Forsyth, ${ }^{b}$ H. Q. Nimal Gunaratne, ${ }^{a}$ Mark Nieuwenhuyzen, ${ }^{a}$ Peter \\ Nockemann, ${ }^{a}$ Alberto V. Puga, ${ }^{* a, c}$ Kenneth R. Seddon, ${ }^{a}$ Geetha Srinivasan ${ }^{a}$ and Keith Whiston ${ }^{b}$ \\ s Received (in $X X X, X X X)$ Xth $X X X X X X X X X 20 X X$, Accepted Xth XXXXXXXXX 20XX \\ DOI: $10.1039 / \mathbf{b 0 0 0 0 0 0 x}$
}

A wide range of room temperature ionic liquids based on the 3-methylpiperdinium cation core were produced from 3-methylpiperidine, which is a derivative of DYTEK ${ }^{\circledR}$ A amine. First, reaction with 1bromoalkanes or 1-bromoalkoxyalkanes generated the corresponding tertiary amines $\left(\mathrm{Rm}_{\beta} \mathrm{pip}, \mathrm{R}=\right.$ alkyl

10 or alkoxyalkyl); further quaternisation reactions with the appropriate methylating agents yielded the quaternary $\left[\mathrm{Rmm}_{\beta}\right.$ pip $] \mathrm{X}$ salts $\left(\mathrm{X}^{-}=\mathrm{I}^{-},\left[\mathrm{CF}_{3} \mathrm{CO}_{2}\right]^{-}\right.$or $\left.[\mathrm{OTf}]^{-} ; \mathrm{Tf}=-\mathrm{SO}_{2} \mathrm{CF}_{3}\right)$, and $\left[\mathrm{Rmm}_{\beta}\right.$ pip] $\left[\mathrm{NTf}_{2}\right]$ were prepared by anion methatesis from the corresponding iodides. All $\left[\mathrm{NTf}_{2}\right]^{-}$salts are liquid at room temperature. $\left[\mathrm{Rmm}_{\beta}\right.$ pip $] \mathrm{X}\left(\mathrm{X}^{-}=\mathrm{\Gamma}^{-},\left[\mathrm{CF}_{3} \mathrm{CO}_{2}\right]^{-}\right.$or $\left.[\mathrm{OTf}]^{-}\right)$are low-melting solids when $\mathrm{R}=$ alkyl, but room temperature liquids upon introduction of ether functionalities on $\mathrm{R}$. Neither of the

15 3-methylpiperdinium ionic liquids showed any signs of crystallisation, even well below $0{ }^{\circ} \mathrm{C}$. Some related non- $C$-substituted piperidinium and pyrrolidinium analogues were prepared and studied for comparison. Crystal structures of 1-hexyl-1,3-dimethylpiperidinium tetraphenylborate, 1-butyl-3methylpiperidinium bromide, 1-(2-methoxyethyl)-1-methylpiperidinium chloride and 1-(2-

methoxyethyl)-1-methylpyrrolidinium bromide are reported. Extensive structural and physical data is

20 collected and compared to literature data, with special emphasis on the systematic study of cation ring size and/or asymmetry effects on density, viscosity and ionic conductivity, allowing general trends to be outlined. Cyclic voltammetry shows that 3 -methylpiperidinium ionic liquids, similarly to azepanium, piperidinium or pyrrolidinium counterparts, are extremely electrochemically stable; the portfolio of useful alternatives for safe and high-performing electrolytes is thus greatly extended.

\section{${ }_{25}$ Introduction}

The stability of electrolytes at highly negative electrode potentials is a crucial aspect for device performance, especially in the case of lithium batteries whereby the anode (negative electrode) operates at voltages around that of the $\mathrm{Li}^{+} / \mathrm{Li}$ redox ${ }_{30}$ pair. ${ }^{1,2,3,4}$ At present, most commercial lithium ion rechargeable batteries use solutions of lithium salts in organic solvents $\left(\mathrm{Li}\left[\mathrm{PF}_{6}\right]\right.$ and cyclic carbonates being the most frequently employed) as electrolytes. ${ }^{3}$ Nevertheless, there are two main drawbacks associated with such systems: $(a)$ the organic solvent 35 is inherently flammable and, thus, fire hazards are unavoidable; ${ }^{1}$ and (b) electrolyte decomposition on the commonly-used carbon-based electrode surface greatly limits charge/discharge cycle life of the battery. ${ }^{5}$ Given such a challenging design, further research devoted to improved safety, cell life and energy density 40 is essential.

As seen above, the problematic areas for lithium batteries include two electrolyte-related issues: flammability and electrochemical decomposition. Specifically, these arise through electrolyte volatility with organic solvents, and restricted 45 electrochemical windows. In an ideal battery, the electrolytes would be non-volatile, non-flammable and with an electrochemical window greater than $5 \mathrm{~V}$. The class of electrolytes which are characterised as ionic liquids have attracted burgeoning attention over the past decade and this work has been 50 extensively reviewed elsewhere., 7, 8-10 Ionic liquids are inherently conducting ${ }^{11}$ and some of them exhibit electrochemical windows significantly in excess of those exhibited by conventional organic solvents, ${ }^{10,12}$ thus allowing increased cell voltages and in turn improving energy densities. ${ }^{4,9,13}$

55 The majority of electrochemical studies have been focussed upon ionic liquids based on quaternary aliphatic phosphonium ${ }^{12}$, 14 and ammonium ${ }^{15}, 16,17$ cations. In particular, the cathodic stability, i.e. resistance to reduction, is most frequently dictated by the cation. 1,3-Dialkylimidazolium ionic liquids are more ${ }_{60}$ prone to reduction than those based on aliphatic cations, since the former have both relatively acidic hydrogen atoms and vacant low-lying $\pi^{*}$ orbitals. $^{8,10,18,19}$ However, even these systems containing aromatic cations exhibit wider electrochemical windows than the majority of conventional organic media. ${ }^{19}$ The 65 differing cathodic stabilities are well illustrated by comparing the electrochemical windows of the bis $\{$ (trifluoromethyl)sulfonyl $\}$ amide (bistriflamide; $\left[\mathrm{NTf}_{2}\right]^{-}$) salts of the cations 1-butyl-3-methylimidazolium $\left(\left[\mathrm{C}_{4} \mathrm{mim}\right]^{+}\right), 1$-butyl1-methylpyrrolidinium $\quad\left(\left[\mathrm{C}_{4} \mathrm{mpyrr}\right]^{+}\right)$or 1-butyl70 1-methylpiperidinium $\left(\left[\mathrm{C}_{4} \text { mpip }\right]^{+}\right)$, which have values of $4.3,{ }^{20}$ $5.5^{17}$ and $5.3 \mathrm{~V},{ }^{21}$ respectively. Moreover, a number of reports have demonstrated that ionic liquids based on alicyclic ammonium cations can enable $\mathrm{Li}^{0}$ plating/stripping cycles to be 
performed, 6, 14, 22 opening new possibilities for the fabrication of safe reversible lithium metal batteries. Despite these promising results, real applications of ionic liquid electrolytes for lithium batteries and other power devices have yet to be accomplished. 5 This is mainly due to the relatively low ionic conductivities of electrolytes composed of lithium salts and ionic liquids, and their poor lithium transference numbers. ${ }^{9}$ Nevertheless, addition of small amounts of molecular solvents may improve these shortcomings without compromising the non-flammability of the 10 electrolyte $^{23}$ or by keeping a good cycling performance. ${ }^{21,24}$

It was recently shown that, for ionic liquids based on alicyclic cations, decreasing the ring size causes viscosity to decrease in the following order: azepanium $>$ piperidinium $>$ pyrrolidinium (ring sizes: $7>6>5$ ). ${ }^{25,}{ }^{26}$ As expected, the conductivity of these 15 ionic liquids showed the reverse trend. Furthermore, the introduction of ether linkages into the aliphatic side-chains of these cations dramatically enhances ionic mobility. ${ }^{30}$ We report here an extension of our earlier studies, along with a systematic comparison of ionic liquids with a variety

20 of alicyclic cationic cores, including their preparation, and physical and electrochemical properties, with a particular focus on a large new series of 1-alkyl-1,3-dimethylpiperidinium

${ }_{25}\left(\left[\mathrm{C}_{n} \mathrm{~mm}_{\beta} \mathrm{pip}\right]^{+}\right)$ionic liquids.

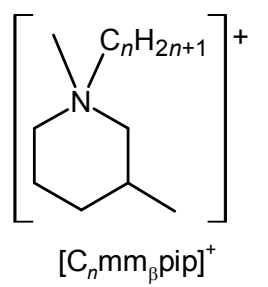

\section{Experimental}

\section{Materials and techniques}

The materials used were sourced as follows: 3-methylpiperidine ${ }^{27}$ (99\%), 1-bromobutane (99\%), 1-bromo-2-methoxyethane (95\%), 30 1-chloro-2-methoxyethane $\quad$ (98\%), 1-bromo-2-(2methoxyethoxy)ethane (95\%), methyl trifluoromethanesulfonate (98+\%), 1-methylpyrrolidine (99+\%), 1-methylpiperidine (98+\%), ethanenitrile and dichloromethane (puriss.) ex SigmaAldrich; iodomethane (99\%), ex Alfa Aesar; 1-bromohexane $35(98+\%)$ and sodium tetraphenylborate $(99.5+\%)$ ex Fluka; methyl trifluoroethanoate (97\%) ex Lancaster; lithium bis $\{$ (trifluoromethyl)sulfonyl $\}$ amide ex $3 \mathrm{M}$; and propanone (Chromanorm) ex HiPerSolv. All reagents were used as received, except ethanenitrile, which was and distilled from $\mathrm{CaH}_{2}$, and 40 methyl trifluoromethanesulfonate and methyl trifluoroethanoate, which where distilled under a dinitrogen atmosphere prior to use. These last two reagents and iodomethane are extremely hazardous, and must be handled with extreme caution. ${ }^{28}$

The following salts were prepared by methods similar to (or ${ }_{45}$ adapted from) those previously described elsewhere: $\left[\mathrm{MeOC}_{2} \mathrm{mpyrr}_{\mathrm{Br}}{ }^{29-31} \quad\left[\mathrm{MeOC}_{2} \mathrm{OC}_{2} \mathrm{mpyrr}_{\mathrm{Br}}{ }^{29,}{ }^{29}\right.\right.$ $\left[\mathrm{MeOC}_{2} \mathrm{mpyrr}_{[}\left[\mathrm{NTf}_{2}\right],{ }^{29-31}\left[\mathrm{MeOC}_{2} \mathrm{OC}_{2} \mathrm{mpyrr}_{[}\left[\mathrm{NTf}_{2}\right]^{29,} 32\right.\right.$ and $\left[\mathrm{MeOC}_{2} \mathrm{mpip}\right]\left[\mathrm{NTf}_{2}\right]^{30}, 33$ (see Schemes 1 and 2 below for structures related to each abbreviation). Their synthetic 50 procedures, as performed in this work, are fully described below.

Microanalyses and electrospray mass spectrometry were performed by Analytical Services and Environmental Projects (ASEP, Queen's University of Belfast). Water contents were determined using a Cou-Lo Compact (version 08.05) Karl Fischer 55 titrator, and titration solutions from Riedel-de-Haën. The water contents were $<200,<400$ and $<500$ ppm for $\left[\mathrm{NTf}_{2}\right]^{-}$,
$\left[\mathrm{CF}_{3} \mathrm{CO}_{2}\right]^{-}$and $[\mathrm{OTf}]^{-}$(liquid) salts, respectively. ${ }^{1} \mathrm{H}$ (500.13 MHz), ${ }^{13} \mathrm{C}(125.76 \mathrm{MHz}),{ }^{1} \mathrm{H}-{ }^{1} \mathrm{H}$ COSY (correlation spectroscopy) and ${ }^{1} \mathrm{H}-{ }^{13} \mathrm{C}$ HMQC (heteronuclear multiple${ }_{60}$ quantum correlation spectroscopy) NMR spectra were recorded for $\mathrm{CDCl}_{3}$ solutions of the samples at ca. $20^{\circ} \mathrm{C}$ on a Bruker Avance DRX 500 spectrometer. Melting points and other phase transition temperatures were recorded from the second heating cycles of differential scanning calorimetry (DSC) traces on a TA ${ }_{65}$ DSC Q2000 instrument with liquid dinitrogen cryostatic cooling (5-20 mg samples, $5{ }^{\circ} \mathrm{C} \mathrm{min}^{-1}$ heating and cooling rates under dinitrogen). Thermal decomposition profiles were determined by thermogravimetric analysis (TGA) using a TA TGA Q5000 instrument at $5^{\circ} \mathrm{C} \mathrm{min}{ }^{-1}$ heating ramp, under a dinitrogen flow. 70 Densities were determined at $25^{\circ} \mathrm{C}$, using an Anton Paar DMA $4500 \mathrm{M}$ oscillating tube density meter. Sample size was $1 \mathrm{~cm}^{3}$. Measurements of viscosity were carried out using a Bohlin Gemini Rotonetic Drive 2 cone and plate viscometer, equipped with a Bohlin Instruments Peltier circulating heater under a 75 dinitrogen flow. Conductivity measurements were carried out using a Mettler Toledo SevenEasy conductivity meter at $25^{\circ} \mathrm{C}$.

\section{Cyclic voltammetry}

Voltammetric experiments were carried out using a PCcontrolled microAutolab Type III potentiostat, and performed in a 80 three-electrode arrangement with a glassy carbon $(3 \mathrm{~mm}$ diameter) as the working electrode (WE) and a bright platinum coil as the counter electrode (CE). Platinum WEs were also used, resulting in essentially identical potential limits. The CE surface area was maintained considerably larger than that of the WE to 85 ensure that all current limitations in the cell were due to the WE response. All potentials were measured with respect to a $\mathrm{Ag} / \mathrm{Ag}^{+}$ couple $\left(0.01 \mathrm{M} \mathrm{Ag}\left[\mathrm{NO}_{3}\right]\right.$ in $\left[\mathrm{C}_{4} \mathrm{mim}\right]\left[\mathrm{NO}_{3}\right], E \approx-0.1 \mathrm{~V}$ vs. ferrocene/ferrocenium) separated from the bulk solution via a glass frit. For ethanenitrile solutions, a similar reference was 90 employed with $\mathrm{Ag}\left[\mathrm{NO}_{3}\right]$ in $0.1 \mathrm{M}$ tetrabutylammonium perchlorate. The $I R$-drop was uncompensated. The glassy carbon electrode was polished using diamond pastes (Kemet, UK) of decreasing particle size $(6-0.1 \mu \mathrm{m})$ on soft lapping pads. Prior to all experiments, all solutions were purged by bubbling argon 95 (dried through $4 \AA$ molecular sieves) for at least $10 \mathrm{~min}$. A positive pressure of Ar was maintained above the surface of the electrolyte throughout the experiments. The cyclic voltammograms for pure ionic liquids showed bulk oxidation and reduction processes at positive and negative potentials, 100 respectively, which define their electrochemical windows. However, the current magnitudes associated with such events are small, due to slow diffusivity. The derivatives of the scans were used, and the electrochemical window defined as the potential range between the midpoints in the sudden current changes for 105 oxidation and reduction. For comparison, cyclic voltammograms of $0.1 \mathrm{M}$ solutions of some ionic liquids in ethanenitrile were recorded; sharper current increases were observed, as expected due to the higher diffusion rates. Electrochemical window data from pure and solution samples agree within $\pm 0.2 \mathrm{~V}$.

\section{X-Ray crystallography}

Single crystals of $\quad\left[\mathrm{C}_{6} \mathrm{~mm}_{\beta}\right.$ pip $]\left[\mathrm{BPh}_{4}\right], \quad\left[\mathrm{C}_{4} \mathrm{Hm}_{\beta} \mathrm{pip}\right] \mathrm{Br}$ $\left(\left[\mathrm{C}_{4} \mathrm{Hm}_{\beta} \mathrm{pip}^{+}=1\right.\right.$-butyl-3-methylpiperidinium), [ $\left.\mathrm{MeOC} \mathrm{C}_{2} \mathrm{mpip}\right] \mathrm{Cl}$ and $\left[\mathrm{MeOC}_{2} \mathrm{mpyrr}\right] \mathrm{Br}$ suitable for X-ray diffraction (XRD) were 
obtained. Colourless large crystals of $\left[\mathrm{C}_{6} \mathrm{~mm}_{\beta} \mathrm{pip}\right]\left[\mathrm{BPh}_{4}\right]$ were grown by slow evaporation from a saturated solution in propanone at $c a .5{ }^{\circ} \mathrm{C}$. Single crystals of $\left[\mathrm{C}_{4} \mathrm{Hm}_{\beta}\right.$ pip $] \mathrm{Br}$ grew serendipitously from the crude mixture of the attempted reaction 5 between $\mathrm{C}_{4} \mathrm{~m}_{\beta}$ pip and 1-bromo-2-methoxyethane in $\mathrm{CH}_{3} \mathrm{CN}$. Pale yellow needles of $\left[\mathrm{MeOC}_{2} \mathrm{mpip}\right] \mathrm{Cl}$ were grown by slowly cooling down a hot solution in $\mathrm{CH}_{3} \mathrm{CN}$. Single crystals of $\left[\mathrm{MeOC}_{2}\right.$ mpyrr] $\mathrm{Br}$ were grown by recrystallisation from a hot saturated solution in a propanone/1-propanol mixture (16:1 by 10 volume) at $c a .5^{\circ} \mathrm{C}$.

Crystal data for $\left[\mathrm{C}_{6} \mathrm{~mm}_{\beta}\right.$ pip $]\left[\mathrm{BPh}_{4}\right]$ were collected at $c a .150 \mathrm{~K}$ using a Bruker KAPPA CCD diffractometer with graphite monochromated Mo- $\mathrm{K}_{\alpha}$ radiation in a dinitrogen stream. Crystal data for $\left[\mathrm{C}_{4} \mathrm{Hm}_{\beta} \mathrm{pip}\right] \mathrm{Br}$, $\left[\mathrm{MeOC}_{2} \mathrm{mpip}\right] \mathrm{Cl}$ and $\left[\mathrm{MeOC}_{2} \mathrm{mpyrr}\right] \mathrm{Br}$ 15 were collected at the EPSRC National Crystallographic Service $(\mathrm{NCS})^{34}$ using a Bruker Nonius KAPPA CCD diffractometer with a FR591 rotating anode and a molybdenum target at $c a .120 \mathrm{~K}$ in a dinitrogen stream. Lorentz and polarisation corrections were applied. The structures were solved by direct methods. ${ }_{20}$ Non-hydrogen atoms were refined with anisotropic thermal parameters. Hydrogen atom positions were added at idealised positions and a riding model with fixed thermal parameters $\left(U_{\mathrm{ij}}=1.2 U_{\mathrm{eq}}\right.$ for the atom to which they are bonded (1.5 for methyl)), was used for subsequent refinements. The function 25 minimised was $\Sigma\left[w\left(\left|F_{0}\right|^{2}-\left|F_{\mathrm{c}}\right|^{2}\right)\right]$ with reflection weights $w^{-1}=\left[\sigma^{2}\left|F_{0}\right|^{2}+\left(g_{1} P\right)^{2}+\left(g_{2} P\right)\right]$ where $P=\left[\max \left|F_{0}\right|^{2}+2\left|F_{\mathrm{c}}\right|^{2}\right] / 3$. The SHELXTL package was used for structure solution and refinement. $^{35}$ For the refinement of $\left[\mathrm{C}_{4} \mathrm{Hm}_{\beta} \mathrm{pip}\right] \mathrm{Br}$ and $\left[\mathrm{MeOC}_{2} \mathrm{mpyrr}_{\mathrm{Br}}\right.$, OLEX2 was used. ${ }^{36}$

30 Search procedures in the Cambridge Structural Database (CSD) were carried out using ConQuest $1.13 .{ }^{37}$ The CSD (version 5.34, updated November 2012) was examined using the following criteria: $3 \mathrm{D}$ coordinates determined, with no errors and no powder structures.

\section{Amine synthesis}

NMR data are listed in tables in the ESI (this applies to all the prepared amines).

1-Butyl-3-methylpiperidine $\quad\left(\mathbf{C}_{4} \mathbf{m}_{\beta} \mathbf{p i p}\right) . \quad$ 1-Bromobutane $(30.00 \mathrm{~g}, 218.9 \mathrm{mmol})$ was added dropwise to a stirring solution 40 of 3-methylpiperidine $(20.00 \mathrm{~g}, 201.7 \mathrm{mmol})$ in propanone $\left(120 \mathrm{~cm}^{3}\right)$ cooled in an ice-water bath. Anhydrous potassium carbonate $(30.5 \mathrm{~g}, 221 \mathrm{mmol})$ was then added and the mixture was vigorously stirred at room temperature for $24 \mathrm{~h}$. The resulting suspension was filtered through a sintered glass frit and 45 the filtrate concentrated under reduced pressure at $45^{\circ} \mathrm{C}$ in a rotary evaporator. A yellowish suspension was thus obtained and distilled in vacuo $\left(32-33{ }^{\circ} \mathrm{C}, 4.5-5.0\right.$ mbar) to give $\mathrm{C}_{4} \mathrm{~m}_{\beta}$ pip as a colourless liquid $(22.91 \mathrm{~g}, 73.1 \%)$. ESI-MS: $\mathrm{m} / \mathrm{z} 156.1753$ $\left([\mathrm{M}+\mathrm{H}]^{+}, 100 \%\right)$; calc. for $\mathrm{C}_{10} \mathrm{H}_{22} \mathrm{~N}: 156.1752$.

${ }_{50}$ 1-Hexyl-3-methylpiperidine ( $\mathbf{C}_{6} \mathbf{m}_{\beta}$ pip). $\mathrm{C}_{6} \mathrm{~m}_{\beta}$ pip was obtained by a similar procedure to that used for $\mathrm{C}_{4} \mathrm{~m}_{\beta}$ pip, from 3-methylpiperidine $(20.00 \mathrm{~g}, 201.7 \mathrm{mmol})$ in propanone $\left(120 \mathrm{~cm}^{3}\right)$, 1-bromohexane $(36.46 \mathrm{~g}, 220.9 \mathrm{mmol})$ and anhydrous potassium carbonate $(30.6 \mathrm{~g}, 222 \mathrm{mmol})$. After distillation in 55 vacuo $\left(62-65^{\circ} \mathrm{C}, 9.0-10 \mathrm{mbar}\right), \mathrm{C}_{6} \mathrm{~m}_{\beta}$ pip was obtained as a colourless liquid (28.66 g, 77.5\%). ESI-MS: $\mathrm{m} / \mathrm{z} 184.2051$ $\left([\mathrm{M}+\mathrm{H}]^{+}, 100 \%\right)$; calc. for $\mathrm{C}_{12} \mathrm{H}_{26} \mathrm{~N}$ : 184.2060 .

\section{1-(2-Methoxyethyl)-3-methylpiperidine}

$\left(\mathrm{MeOC}_{2} \mathrm{~m}_{\beta}\right.$ pip). $\mathrm{MeOC}_{2} \mathrm{~m}_{\beta}$ pip was obtained by a similar procedure to that used ${ }_{60}$ for $\mathrm{C}_{4} \mathrm{~m}_{\beta}$ pip, from 3-methylpiperidine $(16.04 \mathrm{~g}, 161.7 \mathrm{mmol})$ in propanone $\left(90 \mathrm{~cm}^{3}\right), \quad$ 1-bromo-2-methoxyethane $\quad(23.22 \mathrm{~g}$, $167.1 \mathrm{mmol})$ and anhydrous potassium carbonate $(23.11 \mathrm{~g}$, $167.2 \mathrm{mmol})$. After distillation in vacuo $\left(38-40^{\circ} \mathrm{C}\right.$, 0.56-0.60 mbar), $\mathrm{MeOC}_{2} \mathrm{~m}_{\beta}$ pip was obtained as a colourless 65 liquid (20.20 g, 79.4\%). ESI-MS: $m / z 158.1535\left([\mathrm{M}+\mathrm{H}]^{+}, 100 \%\right)$; calc. for $\mathrm{C}_{9} \mathrm{H}_{20} \mathrm{NO}$ : 158.1545 .

\section{1-[2-(2-Methoxyethoxy)ethyl]-3-methylpiperidine}

( $\mathbf{M e O C}_{2} \mathbf{O C}_{2} \mathbf{m}_{\beta}$ pip). $\mathrm{MeOC}_{2} \mathrm{OC}_{2} \mathrm{~m}_{\beta}$ pip was obtained by a similar procedure to that used for $\mathrm{C}_{4} \mathrm{~m}_{\beta}$ pip, from 70 3-methylpiperidine $(12.74 \mathrm{~g}, 128.4 \mathrm{mmol})$ in propanone $\left(80 \mathrm{~cm}^{3}\right)$, 1-bromo-2-(2-methoxyethoxy)ethane $(25.58 \mathrm{~g}, 139.7 \mathrm{mmol})$ and anhydrous potassium carbonate $(19.5 \mathrm{~g}, 141 \mathrm{mmol})$. After distillation in vacuo $\left(65^{\circ} \mathrm{C}, 0.12-0.15\right.$ mbar $), \mathrm{MeOC}_{2} \mathrm{OC}_{2} \mathrm{~m}_{\beta}$ pip was obtained as a colourless liquid (18.97 g, 73.4\%). ESI-MS: $75 \mathrm{~m} / z 202.1802\left([\mathrm{M}+\mathrm{H}]^{+}, 100 \%\right)$; calc. for $\mathrm{C}_{11} \mathrm{H}_{24} \mathrm{NO}_{2}: 202.1807$.

1-(2-Methoxyethyl)piperidine ( $\mathbf{M e O C}_{2}$ pip). $\mathrm{MeOC}_{2}$ pip was obtained by a similar procedure to that used for $\mathrm{C}_{4} \mathrm{~m}_{\beta}$ pip, from piperidine $(16.52 \mathrm{~g}, 194.0 \mathrm{mmol})$ in propanone $\left(100 \mathrm{~cm}^{3}\right), 1$ bromo-2-methoxyethane $(28.50 \mathrm{~g}, 205.0 \mathrm{mmol})$ and anhydrous 80 potassium carbonate $(28.5 \mathrm{~g}, 206 \mathrm{mmol})$. After distillation in vacuo $\left(37-39{ }^{\circ} \mathrm{C}, 3.0-3.3 \mathrm{mbar}\right), \mathrm{MeOC}_{2}$ pip was obtained as a colourless liquid (12.96 g, 46.6\%).

\section{Ionic liquid synthesis}

NMR data are listed in tables in the ESI (this applies to all the 85 prepared salts).

1-Butyl-1,3-dimethylpiperidinium iodide ([ $\left.\left.\mathrm{C}_{\mathbf{4}} \mathrm{mm}_{\beta} \mathbf{p i p}\right] \mathbf{I}\right)$. Iodomethane $(9.63 \mathrm{~g}, 67.8 \mathrm{mmol})$ was added dropwise to a stirred solution of $\mathrm{C}_{4} \mathrm{~m}_{\beta}$ pip $(9.99 \mathrm{~g}, 64.3 \mathrm{mmol})$ in $\mathrm{CH}_{2} \mathrm{Cl}_{2}\left(10 \mathrm{~cm}^{3}\right)$ cooled in an ice-water bath. The reaction mixture was then 90 allowed to warm to room temperature and stirred until complete conversion (ca. $3 \mathrm{~h}$ ) of the amine, as determined by ${ }^{1} \mathrm{H}$ NMR spectroscopy. Volatiles were removed under reduced pressure and the resulting solid dried in vacuo $\left(70{ }^{\circ} \mathrm{C}, 0.05\right.$ mbar $)$ for $24 \mathrm{~h}$ to yield $\left[\mathrm{C}_{4} \mathrm{~mm}_{\beta}\right.$ pip]I $(18.93 \mathrm{~g}, 99.0 \%)$ as a pale yellow solid. ${ }_{95}$ Found: $\mathrm{C}, 44.2 ; \mathrm{H}, 7.6 ; \mathrm{N}, 4.7$. Calc. for $\mathrm{C}_{11} \mathrm{H}_{24} \mathrm{IN}$ : C, 44.45; $\mathrm{H}$, 8.14; N, 4.71\%. ESI-MS; +ve mode: $m / z 170.1915\left(\mathrm{M}^{+}, 100 \%\right)$; calc. for $\mathrm{C}_{11} \mathrm{H}_{24} \mathrm{~N}$ : 170.1909 . - ve mode: $126.9041\left(\mathrm{M}^{-}, 100 \%\right)$; calc. for I: 126.9045 .

1-Hexyl-1,3-dimethylpiperidinium iodide $\quad\left(\left[\mathrm{C}_{6} \mathrm{~mm}_{\beta} \mathrm{pip}\right] \mathrm{I}\right)$. $100\left[\mathrm{C}_{6} \mathrm{~mm}_{\beta}\right.$ pip]I was prepared by a similar procedure to that used for [C $\mathrm{C}_{4} \mathrm{~mm}_{\beta}$ pip]I from $\mathrm{CH}_{3} \mathrm{I}(11.90 \mathrm{~g}, 83.84 \mathrm{mmol})$ and $\mathrm{C}_{6} \mathrm{~m}_{\beta}$ pip ( $15.27 \mathrm{~g}, 83.29 \mathrm{mmol})$ in $\mathrm{CH}_{2} \mathrm{Cl}_{2}\left(20 \mathrm{~cm}^{3}\right)$, to yield a pale yellow solid (26.35 g, 97.3\%). Found: C, 48.0; H, 8.4; N, 4.3. Calc. for $\mathrm{C}_{13} \mathrm{H}_{28} \mathrm{IN}$ : C, 48.00; H, 8.68; N, 4.31\%. ESI-MS; +ve mode: $105 \mathrm{~m} / z$ 199.2291 $\left(\mathrm{M}^{+}, 100 \%\right)$; calc. for $\mathrm{C}_{13} \mathrm{H}_{28} \mathrm{~N}$ : 199.2299. -ve mode: $126.9041\left(\mathrm{M}^{-}, 100 \%\right)$; calc. for I: 126.9045 .

1-(2-Methoxyethyl)-1,3-dimethylpiperidinium iodide ([MeOC ${ }_{2} \mathbf{m m}_{\boldsymbol{\beta}}$ pip]I). $\left[\mathrm{MeOC}_{2} \mathrm{~mm}_{\beta}\right.$ pip]I was prepared by a similar procedure to that used for $\left[\mathrm{C}_{4} \mathrm{~mm}_{\beta}\right.$ pip]I from $\mathrm{CH}_{3} \mathrm{I}$ 
(7.85 g, $55.3 \mathrm{mmol})$ and $\mathrm{MeOC}_{2} \mathrm{~m}_{\beta}$ pip $(8.69 \mathrm{~g}, 55.3 \mathrm{mmol})$ in $\mathrm{CH}_{2} \mathrm{Cl}_{2}\left(20 \mathrm{~cm}^{3}\right)$, to yield a yellow solid $(16.27 \mathrm{~g}, 98.4 \%)$. ESIMS; +ve mode: $m / z 172.1695\left(\mathrm{M}^{+}, 100\right)$; calc. for $\mathrm{C}_{10} \mathrm{H}_{22} \mathrm{NO}$ : 172.1701. -ve mode: 126.9039 (M , 100); calc. for I: 126.9045.

\section{1-[2-(2-Methoxyethoxy)ethyl]-1,3-dimethylpiperidinium} iodide ([MeOC $\mathbf{O C C}_{2} \mathbf{m m}_{\boldsymbol{\beta}}$ pip]I). $\left[\mathrm{MeOC}_{2} \mathrm{OC}_{2} \mathrm{~mm}_{\beta} \mathrm{pip}\right] \mathrm{I}$ was prepared by a similar procedure to that used for $\left[\mathrm{C}_{4} \mathrm{~mm}_{\beta}\right.$ pip]I from $\mathrm{CH}_{3} \mathrm{I}(7.84 \mathrm{~g}, 55.2 \mathrm{mmol})$ and $\mathrm{MeOC}_{2} \mathrm{OC}_{2} \mathrm{~m}_{\beta}$ pip (11.08 g, $55.05 \mathrm{mmol})$ in $\mathrm{CH}_{2} \mathrm{Cl}_{2}\left(15 \mathrm{~cm}^{3}\right)$, to yield a viscous yellow liquid 10 (18.72 g, 99.0\%). Found: $\mathrm{C}, 41.7 ; \mathrm{H}, 7.95 ; \mathrm{N}, 4.0$. Calc. for $\mathrm{C}_{12} \mathrm{H}_{26} \mathrm{INO}_{2}$ : C, 41.99; H, 7.63; N, 4.08\%. ESI-MS; +ve mode: $m / z 216.1969\left(\mathrm{M}^{+}, 100\right)$; calc. for $\mathrm{C}_{10} \mathrm{H}_{26} \mathrm{NO}_{2}$ : 216.1964. -ve mode: $126.9035\left(\mathrm{M}^{-}, 100\right)$; calc. for I: 126.9045 .

\section{1-(2-Methoxyethyl)-1-methylpiperidinium}

chloride

15 ([MeOC ${ }_{2}$ mpip]Cl). A mixture of 1-methylpiperidine $(8.01 \mathrm{~g}$, $80.77 \mathrm{mmol})$, 1-chloro-2-methoxyethane $(9.75 \mathrm{~g}, 103.1 \mathrm{mmol})$ and $\mathrm{CH}_{3} \mathrm{CN}\left(10 \mathrm{~cm}^{3}\right)$ was stirred at $90{ }^{\circ} \mathrm{C}$ in a pressure-sealed glass vessel for $24 \mathrm{~h}$ under a dinitrogen atmosphere. Volatiles were removed under reduced pressure and the resulting solid 20 washed with diethyl ether $\left(3 \times 10 \mathrm{~cm}^{3}\right)$ and dried in vacuo $\left(70{ }^{\circ} \mathrm{C}\right.$, 0.05 mbar) for $24 \mathrm{~h}$ yielding $\left[\mathrm{MeOC}_{2} \mathrm{mpip}\right] \mathrm{Cl}$ as a pale yellow crystalline solid (10.09 g, 64.5\%).

\section{1-(2-Methoxyethyl)-1-methylpyrrolidinium}

bromide ([MeOC ${ }_{2}$ mpyrr]Br). A mixture of 1-methylpyrrolidine (6.13 g, $\left.{ }_{25} 71.99 \mathrm{mmol}\right), 1$-bromo-2-methoxyethane (10.43 g, $\left.75.04 \mathrm{mmol}\right)$ and anhydrous propanone $\left(15 \mathrm{~cm}^{3}\right)$ was stirred under reflux for $24 \mathrm{~h}$ under a dinitrogen atmosphere. Volatiles were removed under reduced pressure and the resulting solid washed with diethyl ether $\left(3 \times 10 \mathrm{~cm}^{3}\right)$ and dried in vacuo $\left(70{ }^{\circ} \mathrm{C}, 0.05 \mathrm{mbar}\right)$ 30 for $24 \mathrm{~h}$ yielding $\left[\mathrm{MeOC}_{2} \mathrm{mpyrr}\right] \mathrm{Br}$ as a pale yellow crystalline solid (11.85 g, 73.4\%).

\section{1-[2-(2-Methoxyethoxy)ethyl]-1-methylpyrrolidinium}

bromide ([MeOC $\mathbf{O C C}_{2}$ mpyrr]Br). $\left[\mathrm{MeOC}_{2} \mathrm{OC}_{2} \mathrm{mpyrr}\right] \mathrm{Br}$ was prepared by a similar procedure to that used for $\left[\mathrm{MeOC}_{2} \mathrm{mpyrr}\right] \mathrm{Br}$ 35 from 1-methylpyrrolidine $(5.36 \mathrm{~g}, 62.95 \mathrm{mmol})$ and 1-bromo-2(2-methoxyethoxy)ethane $(11.55 \mathrm{~g}, 63.10 \mathrm{mmol})$ to yield a pale yellow solid (15.58 g, 92.3\%).

\section{1-Butyl-1,3-dimethylpiperidinium}

bistriflamide $\left(\left[\mathbf{C}_{4} \mathbf{m m}_{\beta} \mathbf{p i p}\right]\left[\mathbf{N T f}_{2}\right]\right)$. A solution of $\mathrm{Li}\left[\mathrm{NTf}_{2}\right] \quad(14.20 \mathrm{~g}$, $4049.46 \mathrm{mmol})$ in water $\left(15 \mathrm{~cm}^{3}\right)$ was thoroughly shaken with a solution of $\left[\mathrm{C}_{4} \mathrm{~mm}_{\beta}\right.$ pip]I $(14.00 \mathrm{~g}, 47.10 \mathrm{mmol})$ in $\mathrm{CH}_{2} \mathrm{Cl}_{2}$ $\left(15 \mathrm{~cm}^{3}\right)$ in a separating funnel. After allowing the mixture to settle, an upper aqueous layer and a lower ionic liquid layer separated. The lower phase was washed with water $\left(5 \times 10 \mathrm{~cm}^{3}\right)$ 45 and then volatiles were removed in vacuo $\left(70{ }^{\circ} \mathrm{C}, 0.05 \mathrm{mbar}\right)$ for $24 \mathrm{~h}$ leaving $\left[\mathrm{C}_{4} \mathrm{~mm}_{\beta}\right.$ pip] $\left[\mathrm{NTf}_{2}\right]$ as a pale yellow liquid $(19.77 \mathrm{~g}$, 93.2\%). Found: $\mathrm{C}, 34.9 ; \mathrm{H}, 5.4 ; \mathrm{N}, 6.2 ; \mathrm{S}, 14.9$. Calc. for $\mathrm{C}_{13} \mathrm{H}_{24} \mathrm{~F}_{6} \mathrm{~N}_{2} \mathrm{O}_{4} \mathrm{~S}_{2}$ : C, 34.66; H, 5.37; N, 6.22; S, 14.24\%.

\section{1-Hexyl-1,3-dimethylpiperidinium}

bistriflamide

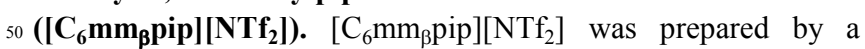
similar procedure to that used for $\left[\mathrm{C}_{4} \mathrm{~mm}_{\beta} \mathrm{pip}\right]\left[\mathrm{NTf}_{2}\right]$ from $\mathrm{Li}\left[\mathrm{NTf}_{2}\right](18.07 \mathrm{~g}, 62.94 \mathrm{mmol})$ and $\left[\mathrm{C}_{6} \mathrm{~mm}_{\beta} \mathrm{pip}\right] \mathrm{I}(20.01 \mathrm{~g}$, $61.52 \mathrm{mmol})$, to yield a yellow liquid (28.22 g, 95.9\%). Found: $\mathrm{C}$, 37.6; H, 5.9; N, 5.9; S, 13.3. Calc. for $\mathrm{C}_{15} \mathrm{H}_{28} \mathrm{~F}_{6} \mathrm{~N}_{2} \mathrm{O}_{4} \mathrm{~S}_{2}$ : C, 37.65; ${ }_{55} \mathrm{H}, 5.90$; N, 5.85; S, $13.40 \%$. ESI-MS; +ve mode: $\mathrm{m} / z \mathbf{z} 198.2206$
$\left(\mathrm{M}^{+}, 100\right)$; calc. for $\mathrm{C}_{13} \mathrm{H}_{28} \mathrm{~N}$ : 198.2216. -ve mode: 279.9187 $\left(\mathrm{M}^{-}, 100\right)$; calc. for $\mathrm{C}_{2} \mathrm{~F}_{6} \mathrm{NO}_{4} \mathrm{~S}_{2}: 279.9173$.

1-(2-Methoxyethyl)-1,3-dimethylpiperidinium bistriflamide

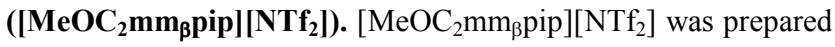
${ }_{60}$ by a similar procedure to that used for $\left[\mathrm{C}_{4} \mathrm{~mm}_{\beta} \mathrm{pip}\right]\left[\mathrm{NTf}_{2}\right]$ from $\mathrm{Li}\left[\mathrm{NTf}_{2}\right](13.12 \mathrm{~g}, 45.70 \mathrm{mmol})$ and $\left[\mathrm{MeOC}_{2} \mathrm{~mm}_{\beta}\right.$ pip]I $(13.38 \mathrm{~g}$, $44.72 \mathrm{mmol})$, to yield a pale yellow liquid $(18.37 \mathrm{~g}, 90.8 \%)$.

\section{1-[2-(2-Methoxyethoxy)ethyl]-1,3-dimethylpiperidinium} bistriflamide $\quad\left(\left[\mathrm{MeOC}_{2} \mathrm{OC}_{2} \mathbf{m m}_{\beta}\right.\right.$ pip][NTf $\left.\left.\mathbf{N T}_{2}\right]\right)$. ${ }_{65}\left[\mathrm{MeOC}_{2} \mathrm{OC}_{2} \mathrm{~mm}_{\beta}\right.$ pip $]\left[\mathrm{NTf}_{2}\right]$ was prepared by a similar procedure to that used for $\left[\mathrm{C}_{4} \mathrm{~mm}_{\beta}\right.$ pip] $\left[\mathrm{NTf}_{2}\right]$ from $\mathrm{Li}\left[\mathrm{NTf}_{2}\right](15.34 \mathrm{~g}$, $53.43 \mathrm{mmol})$ and $\left[\mathrm{MeOC}_{2} \mathrm{OC}_{2} \mathrm{~mm}_{\beta}\right.$ pip]I $(17.92 \mathrm{~g}, 52.21 \mathrm{mmol})$, to yield a yellow liquid (24.28 g, 93.7\%). Found: C, 34.0; H, 5.4; $\mathrm{N}$, 5.2; S, 13.3. Calc. for $\mathrm{C}_{14} \mathrm{H}_{26} \mathrm{~F}_{6} \mathrm{~N}_{2} \mathrm{O}_{6} \mathrm{~S}_{2}$ : C, 33.87; H, 5.28; $\mathrm{N}$, 70 5.64; S, $12.92 \%$. ESI-MS; +ve mode: $m / z 216.1948\left(\mathrm{M}^{+}, 100\right)$; calc. for $\mathrm{C}_{12} \mathrm{H}_{26} \mathrm{NO}_{2}$ : 216.1964. -ve mode: $279.9168\left(\mathrm{M}^{-}, 100\right)$; calc. for $\mathrm{C}_{2} \mathrm{~F}_{6} \mathrm{NO}_{4} \mathrm{~S}_{2}: 279.9173$.

1-(2-Methoxyethyl)-1-methylpiperidinium bistriflamide

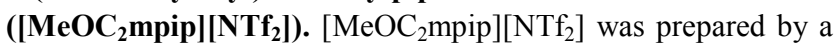
75 similar procedure to that used for $\left[\mathrm{C}_{4} \mathrm{~mm}_{\beta} \mathrm{pip}\right]\left[\mathrm{NTf}_{2}\right]$ from $\mathrm{Li}\left[\mathrm{NTf}_{2}\right](11.03 \mathrm{~g}, 38.42 \mathrm{mmol})$ and $\left[\mathrm{MeOC}_{2} \mathrm{mpip}\right] \mathrm{Cl}(7.33 \mathrm{~g}$, $37.84 \mathrm{mmol}$ ), yielding a pale yellow liquid (15.57 g, 93.9\%).

1-(2-Methoxyethyl)-1-methylpyrrolidinium bistriflamide

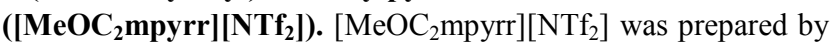
80 a similar procedure to that used for $\left[\mathrm{C}_{4} \mathrm{~mm}_{\beta}\right.$ pip] $\left[\mathrm{NTf}_{2}\right]$ from $\mathrm{Li}\left[\mathrm{NTf}_{2}\right](14.86 \mathrm{~g}, 51.76 \mathrm{mmol})$ and $\left[\mathrm{MeOC}_{2} \mathrm{mpyrr}\right] \mathrm{Br}(11.38 \mathrm{~g}$, $50.77 \mathrm{mmol})$, to yield a yellow liquid (18.96 g, 88.0\%). ESI-MS; +ve mode: $m / z 144.1380\left(\mathrm{M}^{+}, 100\right)$; calc. for $\mathrm{C}_{8} \mathrm{H}_{18} \mathrm{NO}$ : 144.1388. -ve mode: $279.9182\left(\mathrm{M}^{-}, 100\right)$; calc. for $\mathrm{C}_{2} \mathrm{~F}_{6} \mathrm{NO}_{4} \mathrm{~S}_{2}$ : 85279.9173 .

\section{1-[2-(2-Methoxyethoxy)ethyl]-1-methylpyrrolidinium} bistriflamide $\quad\left(\left[\mathrm{MeOC}_{2} \mathrm{OC}_{2}\right.\right.$ mpyrr][NTf $\left.\mathrm{NT}_{2}\right]$ ). $\left[\mathrm{MeOC}_{2} \mathrm{OC}_{2}\right.$ mpyrr] $\left[\mathrm{NTf}_{2}\right]$ was prepared by a similar procedure to that used for $\left[\mathrm{C}_{4} \mathrm{~mm}_{\beta} \mathrm{pip}\right]\left[\mathrm{NTf}_{2}\right]$ from $\mathrm{Li}\left[\mathrm{NTf}_{2}\right] \quad(16.48 \mathrm{~g}$, $9057.40 \mathrm{mmol})$ and $\left[\mathrm{MeOC}_{2} \mathrm{OC}_{2} \mathrm{mpyrr}\right] \mathrm{Br}(15.10 \mathrm{~g}, 56.30 \mathrm{mmol})$, to yield a yellow liquid $(23.71 \mathrm{~g}, 89.9 \%)$. ESI-MS; +ve mode: $m / z 188.1645\left(\mathrm{M}^{+}, 100\right)$; calc. for $\mathrm{C}_{10} \mathrm{H}_{22} \mathrm{NO}_{2}$ : 188.1651. -ve mode: $279.9182\left(\mathrm{M}^{-}, 100\right)$; calc. for $\mathrm{C}_{2} \mathrm{~F}_{6} \mathrm{NO}_{4} \mathrm{~S}_{2}$ : 279.9173 .

1-Butyl-1,3-dimethylpiperidinium trifluoroethanoate ${ }_{95}\left(\left[\mathbf{C}_{4} \mathbf{m m}_{\boldsymbol{\beta}}\right.\right.$ pip] $\left.\left[\mathbf{C F}_{3} \mathbf{C O}_{2}\right]\right)$. A mixture of $\mathrm{C}_{4} \mathrm{~m}_{\beta}$ pip $(10.00 \mathrm{~g}$, $64.40 \mathrm{mmol})$ and methyl trifluoroethanoate $(8.32 \mathrm{~g}, 65.04 \mathrm{mmol})$ was stirred at $60^{\circ} \mathrm{C}$ in a pressure-sealed glass vessel for $24 \mathrm{~h}$ under a dinitrogen atmosphere. Volatiles were removed in vacuo $\left(70{ }^{\circ} \mathrm{C}, 0.05 \mathrm{mbar}\right.$ ) for $24 \mathrm{~h}$ yielding $\left[\mathrm{C}_{4} \mathrm{~mm}_{\beta}\right.$ pip $]\left[\mathrm{CF}_{3} \mathrm{CO}_{2}\right]$ as a 100 pale yellow crystalline solid $(17.65 \mathrm{~g}, 96.7 \%)$. ESI-MS; +ve mode: $m / z 170.1913\left(\mathrm{M}^{+}, 100\right)$; calc. for $\mathrm{C}_{11} \mathrm{H}_{24} \mathrm{~N}$ : 170.1909 . - ve mode: $112.9854\left(\mathrm{M}^{-}, 100\right)$; calc. for $\mathrm{C}_{2} \mathrm{~F}_{3} \mathrm{O}_{2}: 112.9850$.

1-Hexyl-1,3-dimethylpiperidinium

trifluoroethanoate ([ $\left.\left.\mathbf{C}_{6} \mathbf{m m}_{\boldsymbol{\beta}} \mathbf{p i p}\right]\left[\mathbf{C F}_{\mathbf{3}} \mathbf{C O}_{2}\right]\right)$. $\left[\mathrm{C}_{6} \mathrm{~mm}_{\beta}\right.$ pip $]\left[\mathrm{CF}_{3} \mathrm{CO}_{2}\right]$ was prepared by 105 a similar procedure to that used for $\left[\mathrm{C}_{4} \mathrm{~mm}_{\beta}\right.$ pip $]\left[\mathrm{CF}_{3} \mathrm{CO}_{2}\right]$ from $\mathrm{C}_{6} \mathrm{~m}_{\beta}$ pip $(3.31 \mathrm{~g}, 18.1 \mathrm{mmol})$ and methyl trifluoroethanoate $(2.38 \mathrm{~g}, 18.6 \mathrm{mmol})$, to yield a yellow solid $(5.42 \mathrm{~g}, 96.4 \%)$. Found: $\mathrm{C}, 56.4 ; \mathrm{H}, 8.8 ; \mathrm{N}, 4.3$. Calc. for $\mathrm{C}_{15} \mathrm{H}_{28} \mathrm{~F}_{3} \mathrm{NO}_{2}$ : C, 57.86; H, 9.06; N, 4.50\%. ESI-MS; +ve mode: $m / z 198.2209$ (M+1 100 ); 110 calc. for $\mathrm{C}_{13} \mathrm{H}_{28} \mathrm{~N}$ : 198.2216. -ve mode: $112.9851\left(\mathrm{M}^{-}, 100\right)$; 
calc. for $\mathrm{C}_{2} \mathrm{~F}_{3} \mathrm{O}_{2}: 112.9850$.

\section{1-(2-Methoxyethyl)-1,3-dimethylpiperidinium} trifluoroethanoate

([ $\left.\left.\mathrm{MeOC}_{2} \mathrm{~mm}_{\beta} \mathrm{pip}\right]\left[\mathrm{CF}_{3} \mathrm{CO}_{2}\right]\right)$.

$\left[\mathrm{MeOC}_{2} \mathrm{~mm}_{\beta}\right.$ pip] $\left[\mathrm{CF}_{3} \mathrm{CO}_{2}\right]$ was prepared by a similar procedure 5 to that used for $\left[\mathrm{C}_{4} \mathrm{~mm}_{\beta}\right.$ pip $]\left[\mathrm{CF}_{3} \mathrm{CO}_{2}\right]$ from $\mathrm{MeOC}_{2} \mathrm{~m}_{\beta}$ pip $(12.186 \mathrm{~g}, 77.49 \mathrm{mmol})$ and methyl trifluoroethanoate $(10.146 \mathrm{~g}$, $79.23 \mathrm{mmol}$ ), to yield a yellow viscous liquid $(21.23 \mathrm{~g}, 96.0 \%)$. Found: C, 50.0; H, 8.05; N, 5.1. Calc. for $\mathrm{C}_{12} \mathrm{H}_{22} \mathrm{~F}_{3} \mathrm{NO}_{3}$ : C, 50.52; H, 7.77; N, 4.91\%. ESI-MS; +ve mode: $m / z 172.1633\left(\mathrm{M}^{+}, 100\right)$; 10 calc. for $\mathrm{C}_{10} \mathrm{H}_{22} \mathrm{NO}$ : 172.1701. - ve mode: $112.9788\left(\mathrm{M}^{-}, 100\right)$; calc. for $\mathrm{C}_{2} \mathrm{~F}_{3} \mathrm{O}_{2}: 112.9850$.

\section{1-[2-(2-Methoxyethoxy)ethyl]-1,3-dimethylpiperidinium} trifluoroethanoate ([ $\mathrm{MeOC}_{2} \mathrm{OC}_{2} \mathrm{~mm}_{\beta}$ pip] $\left.\left[\mathrm{CF}_{3} \mathrm{CO}_{2}\right]\right)$. $\left[\mathrm{MeOC}_{2} \mathrm{OC}_{2} \mathrm{~mm}_{\beta}\right.$ pip] $\left[\mathrm{CF}_{3} \mathrm{CO}_{2}\right]$ was prepared by a similar 15 procedure to that used for $\left[\mathrm{C}_{4} \mathrm{~mm}_{\beta} \mathrm{pip}\right]\left[\mathrm{CF}_{3} \mathrm{CO}_{2}\right]$ from $\mathrm{MeOC}_{2} \mathrm{OC}_{2} \mathrm{~m}_{\beta}$ pip $(9.378 \mathrm{~g}, \quad 46.59 \mathrm{mmol})$ and methyl trifluoroethanoate $(6.113 \mathrm{~g}, 47.74 \mathrm{mmol})$, to yield a yellow viscous liquid (14.92 g, 97.2\%). Found: C, 49.5; H, 8.6; N, 4.1. Calc. for $\mathrm{C}_{14} \mathrm{H}_{26} \mathrm{~F}_{3} \mathrm{NO}_{4}$ : C, 51.05; H, 7.96; N, 4.25\%. ESI-MS; ${ }_{20}+$ ve mode: $m / z 216.1942\left(\mathrm{M}^{+}, 100\right)$; calc. for $\mathrm{C}_{12} \mathrm{H}_{26} \mathrm{NO}_{2}$ : 216.1964. -ve mode: $112.9845\left(\mathrm{M}^{-}, 100\right)$; calc. for $\mathrm{C}_{2} \mathrm{~F}_{3} \mathrm{O}_{2}$ : 112.9850 .

1-(2-Methoxyethyl)-1-methylpiperidinium trifluoroethanoate ([MeOC $\mathbf{M}_{\mathbf{2}}$ mpip] $\left.\left[\mathbf{C F}_{\mathbf{3}} \mathbf{C O}_{\mathbf{2}}\right]\right) . \quad\left[\mathrm{MeOC}_{2} \mathrm{mpip}\right]\left[\mathrm{CF}_{3} \mathrm{CO}_{2}\right]$ was 25 prepared by a similar procedure to that used for $\left[\mathrm{C}_{4} \mathrm{~mm}_{\beta}\right.$ pip $]\left[\mathrm{CF}_{3} \mathrm{CO}_{2}\right]$ from $\mathrm{MeOC}_{2}$ pip $(6.493 \mathrm{~g}, 45.33 \mathrm{mmol})$ and methyl trifluoroethanoate $(5.963 \mathrm{~g}, 46.57 \mathrm{mmol})$, to yield a yellow liquid (12.203 g, 99.2\%).

1-Butyl-1,3-dimethylpiperidinium trifluoromethanesulfonate ${ }_{30}\left(\left[\mathbf{C}_{\mathbf{4}} \mathbf{m m}_{\boldsymbol{\beta}}\right.\right.$ pip][OTf]). Methyl trifluoromethanesulfonate $(5.21 \mathrm{~g}$, $31.8 \mathrm{mmol}$ ) was added dropwise to the stirred solution of $\mathrm{C}_{4} \mathrm{~m}_{\beta}$ pip (5.00 g, $\left.32.20 \mathrm{mmol}\right)$ in $\mathrm{CH}_{2} \mathrm{Cl}_{2}\left(10 \mathrm{~cm}^{3}\right)$ cooled in an ice-water bath and under a dinitrogen atmosphere. The reaction mixture was then allowed to warm to room temperature while 35 stirring, after which, complete conversion of the amine had occurred, as determined using ${ }^{1} \mathrm{H}$ NMR spectroscopy. After evaporation of the volatiles in vacuo $\left(70{ }^{\circ} \mathrm{C}, 0.05 \mathrm{mbar}\right)$ for $24 \mathrm{~h}$, $\left[\mathrm{C}_{4} \mathrm{~mm}_{\beta}\right.$ pip][OTf] was obtained as a pale yellow solid (10.18 $\mathrm{g}$, 99.0\%). Found: $\mathrm{C}, 44.7, \mathrm{H}, 7.05, \mathrm{~N}, 4.5, \mathrm{~S}, 10.8$. Calc. for ${ }_{40} \mathrm{C}_{12} \mathrm{H}_{24} \mathrm{~F}_{3} \mathrm{NO}_{3} \mathrm{~S}: \mathrm{C}, 45.13, \mathrm{H}, 7.57, \mathrm{~N}, 4.39, \mathrm{~S}, 10.04 \%$. ESI-MS; +ve mode: $m / z 170.1899\left(\mathrm{M}^{+}, 100\right)$; calc. for $\mathrm{C}_{11} \mathrm{H}_{24} \mathrm{~N}$ : 170.1909 . -ve mode: $m / z$ 148.9517 (M-100); calc. for $\mathrm{CF}_{3} \mathrm{O}_{3} \mathrm{~S}: 148.9520$.

1-Hexyl-1,3-dimethylpiperidinium trifluoromethanesulfonate ([ $\mathbf{C}_{\mathbf{6}} \mathbf{m m}_{\beta}$ pip][OTf]). $\left[\mathrm{C}_{6} \mathrm{~mm}_{\beta}\right.$ pip][OTf] was prepared by a ${ }_{45}$ similar procedure to that used for $\left[\mathrm{C}_{4} \mathrm{~mm}_{\beta} \mathrm{pip}\right][\mathrm{OTf}]$ from $\mathrm{C}_{6} \mathrm{~m}_{\beta}$ pip $\quad(2.00 \mathrm{~g}, \quad 10.9 \mathrm{mmol}) \quad$ and methyl trifluoromethanesulfonate $(1.97 \mathrm{~g}, 12.0 \mathrm{mmol})$, to yield a pale yellow solid (3.77 g, 99.5\%). Found: C, 47.9; H, 8.0; N, 3.8; S, 9.9. Calc. for $\mathrm{C}_{14} \mathrm{H}_{28} \mathrm{~F}_{3} \mathrm{NO}_{3} \mathrm{~S}: \mathrm{C}, 48.40 ; \mathrm{H}, 8.12 ; \mathrm{N}, 4.03 ; \mathrm{S}$, 50 9.23\%. ESI-MS; +ve mode: $m / z 198.2209\left(\mathrm{M}^{+}, 100\right)$; calc. for $\mathrm{C}_{13} \mathrm{H}_{28} \mathrm{~N}$ : 198.2216. -ve mode: $148.9506\left(\mathrm{M}^{-}, 100\right)$; calc. for $\mathrm{CF}_{3} \mathrm{O}_{3} \mathrm{~S}: 148.9520$.

1-(2-Methoxyethyl)-1,3-dimethylpiperidinium trifluoromethanesulfonate $\quad\left(\left[\mathrm{MeOC}_{2} \mathrm{~mm}_{\beta}\right.\right.$ pip][OTf]). ${ }_{55}\left[\mathrm{MeOC}_{2} \mathrm{~mm}_{\beta}\right.$ pip][OTf] was prepared by a similar procedure to that used for $\left[\mathrm{C}_{4} \mathrm{~mm}_{\beta}\right.$ pip][OTf] from $\mathrm{MeOC}_{2} \mathrm{~m}_{\beta}$ pip (9.390 g, $59.71 \mathrm{mmol})$ and methyl trifluoromethanesulfonate $(9.801 \mathrm{~g}$, $59.73 \mathrm{mmol})$, to yield a pale brown viscous liquid $(19.07 \mathrm{~g}$, 99.4\%). Found: $\mathrm{C}, 40.7 ; \mathrm{H}, 7.4 ; \mathrm{N}, 4.2 ; \mathrm{S}, 9.9$. Calc. for ${ }_{60} \mathrm{C}_{11} \mathrm{H}_{22} \mathrm{~F}_{3} \mathrm{NO}_{4} \mathrm{~S}: \mathrm{C}, 41.11, \mathrm{H}, 6.90, \mathrm{~N}, 4.36, \mathrm{~S}, 9.98 \%$. ESI-MS; +ve mode: $m / z 172.1683\left(\mathrm{M}^{+}, 100\right)$; calc. for $\mathrm{C}_{10} \mathrm{H}_{22} \mathrm{NO}$ : 172.1701. -ve mode: $m / z 148.9506\left(\mathrm{M}^{-}, 100\right)$; calc. for $\mathrm{CF}_{3} \mathrm{O}_{3} \mathrm{~S}$ : 148.9520 .

\section{1-[2-(2-Methoxyethoxy)ethyl]-1,3-dimethylpiperidinium} ${ }_{65}$ trifluoromethanesulfonate $\quad$ ([MeOC $\mathbf{O C}_{2} \mathbf{m m}_{\beta}$ pip][OTf]). [ $\left.\mathrm{MeOC}_{2} \mathrm{OC}_{2} \mathrm{~mm}_{\beta} \mathrm{pip}\right][\mathrm{OTf}]$ was prepared by a similar procedure to that used for $\left[\mathrm{C}_{4} \mathrm{~mm}_{\beta}\right.$ pip][OTf $]$ from $\mathrm{MeOC}_{2} \mathrm{OC}_{2} \mathrm{~m}_{\beta}$ pip $(10.26 \mathrm{~g}, 50.97 \mathrm{mmol})$ and methyl trifluoromethanesulfonate $(8.791 \mathrm{~g}, 53.57 \mathrm{mmol})$, to yield a yellow viscous liquid $(18.60 \mathrm{~g}$, 70 99.9\%). Found: $\mathrm{C}, 42.3 ; \mathrm{H}, 6.8 ; \mathrm{N}, 3.6 ; \mathrm{S}, 8.9$. Calc. for $\mathrm{C}_{13} \mathrm{H}_{26} \mathrm{~F}_{3} \mathrm{NO}_{5} \mathrm{~S}$ : C, 42.73; H, 7.17, N, 3.83; S, 8.78\%. ESI-MS; +ve mode: $m / z 216.1946\left(\mathrm{M}^{+}, 100\right)$; calc. for $\mathrm{C}_{12} \mathrm{H}_{26} \mathrm{NO}_{2}$ : 216.1964. -ve mode: $m / z 148.9510\left(\mathrm{M}^{-}, 100\right)$; calc. for $\mathrm{CF}_{3} \mathrm{O}_{3} \mathrm{~S}$ : 148.9520 .

\section{1-(2-Methoxyethyl)-1-methylpiperidinium} trifluoromethanesulfonate ([MeOC ${ }_{2}$ mpip][OTf]). [ $\mathrm{MeOC}_{2}$ mpip][OTf] was prepared by a similar procedure to that used for $\left[\mathrm{C}_{4} \mathrm{~mm}_{\beta}\right.$ pip][OTf $]$ from $\mathrm{MeOC}_{2}$ mpip $(6.347 \mathrm{~g}$, $44.30 \mathrm{mmol})$ and methyl trifluoromethanesulfonate $(7.641 \mathrm{~g}$, ${ }_{80} 46.56 \mathrm{mmol}$ ), to yield a pale brown liquid (13.548 g, 99.5\%).

\section{1-Hexyl-1,3-dimethylpiperidinium}

tetraphenylborate $\left(\left[\mathbf{C}_{6} \mathbf{m m}_{\beta}\right.\right.$ pip] $\left.\left[\mathbf{B P h} \mathbf{h}_{4}\right]\right)$. An aqueous solution $\left(15 \mathrm{~cm}^{3}\right)$ of $\mathrm{Na}\left[\mathrm{BPh}_{4}\right]$ (1.052 g, $3.074 \mathrm{mmol})$ was added to a stirred aqueous solution $\left(15 \mathrm{~cm}^{3}\right)$ of $\left[\mathrm{C}_{6} \mathrm{~mm}_{\beta}\right.$ pip]I $(1.000 \mathrm{~g}, 3.074 \mathrm{mmol})$; a white 85 precipitate appeared immediately. After the mixture was stirred for $4 \mathrm{~h}$, the white solid was collected by filtration, washed with water $\left(3 \times 10 \mathrm{~cm}^{3}\right)$, and dried under reduced pressure for $1 \mathrm{~h}$, yielding $\left[\mathrm{C}_{6} \mathrm{~mm}_{\beta}\right.$ pip] $\left[\mathrm{BPh}_{4}\right](1.408 \mathrm{~g}, 88.5 \%)$ as a white solid. Found: C, 85.2; $\mathrm{H}, 9.2$; N, 2.2. Calc. for $\mathrm{C}_{37} \mathrm{H}_{48} \mathrm{BN}$ : C, 85.86; $\mathrm{H}$, 90 9.35, N, 2.71. ESI-MS; +ve mode: $m / z 198.2209$ (M+1 100); calc. for $\mathrm{C}_{13} \mathrm{H}_{28} \mathrm{~N}$ : 198.2222. -ve mode: $m / z 319.1610\left(\mathrm{M}^{-}, 100\right)$; calc. for $\mathrm{C}_{24} \mathrm{H}_{20} \mathrm{~B}: 319.1658$.

\section{Results and discussion}

\section{Synthesis}

95 The new ionic liquids based on 3-methylpiperidinium cations have been synthesised according to Scheme 1 (this method is similar to that used for the production of the isomeric azepanium salts, ${ }^{38,39}$ with good yields for both classes of materials).

The 1-R-3-methylpiperidines ( $\mathrm{Rm}_{\beta} \mathrm{pip}$ ) were prepared by 100 reaction of 3-methylpiperidine (a derivative of DYTEK $^{\circledR}$ A amine, ${ }^{27}$ a common co-product in polyamide manufacture) with the desired alkylating agent (bromoalkanes or bromoalkoxyalkanes) in the presence of potassium carbonate; after vacuum distillation, isolated yields were in the $68-78 \%$ 105 range. The starting 3-methylpiperidine is a racemic mixture and, thus, the derived $\mathrm{N}$-alkylated products are expected to be also racemic mixtures of both possible enantiomers, i.e. the $3 R$ - and $3 S$ - isomers. Other previously reported methods for the synthesis of $\mathrm{C}_{4} \mathrm{~m}_{\beta}$ pip include photoinduced cyclisations of 1-butyl-1110 trimethylsilyl-1-(pent-4-enyl)amine. ${ }^{40}$ 


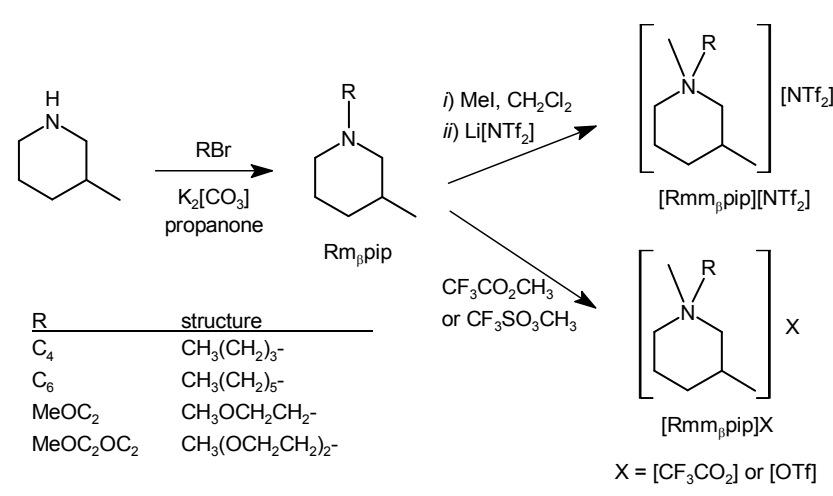

Scheme 1 Syntheses of ionic liquids derived from 3-methylpiperidine.

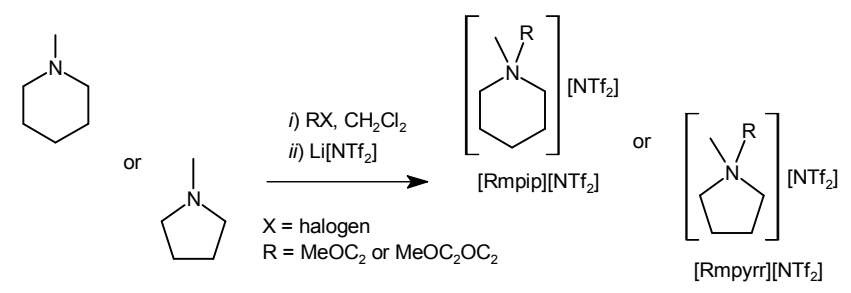

Scheme 2 Synthesis of bistriflamide ionic liquids derived from piperidine $5 \quad$ or pyrrolidine. $\mathrm{R}$ is as defined in Scheme 1.

Methylation reactions on the obtained $\mathrm{Rm}_{\beta}$ pip amines yielded quaternary 1-R-1,3-dimethylpiperidinium salts (see Scheme 1). Iodide and trifluoromethanesulfonate salts $\left(\left[\mathrm{Rmm}_{\beta} \mathrm{pip}\right] \mathrm{X}, \mathrm{X}^{-}=\mathrm{I}^{-}\right.$ or [OTf] $]^{-}$, respectively) were prepared in almost quantitative 10 yields by reactions of the corresponding tertiary amines with iodomethane or methyl trifluoromethanesulfonate, respectively, in dichloromethane at $0{ }^{\circ} \mathrm{C}$. Trifluoroethanoate salts ([Rmm $\beta$ pip $]\left[\mathrm{CF}_{3} \mathrm{CO}_{2}\right]$ ) were obtained by analogous reactions with methyl trifluoroethanoate as the methylating agent in pressure15 sealed glass vessels at $60{ }^{\circ} \mathrm{C}$, a method previously developed for the chloride-free alkylation of 1-methylimidazole. ${ }^{41}$ All these salts were obtained as low melting solids or room temperature ionic liquids, depending on both the anion and the nature of the $\mathrm{R}$ group (as discussed below).

20 Metathetic reactions of $\left[\mathrm{Rmm}_{\beta}\right.$ pip $] \mathrm{I}$ with $\mathrm{Li}\left[\mathrm{NTf}_{2}\right]$ in biphasic water/dichloromethane systems yielded the corresponding $\left[\mathrm{Rmm}_{\beta}\right.$ pip $]\left[\mathrm{NTf}_{2}\right]$ salts in good yields (83-91\%). Thorough washing with water was carried out to ensure lithium iodide removal. In all cases, $\left[\mathrm{Rmm}_{\beta}\right.$ pip $]\left[\mathrm{NTf}_{2}\right]$ were obtained as liquids 25 of moderately low viscosity.

The synthetic pathway depicted in Scheme 1 was also successfully adapted for the preparation of 1-(2-methoxyethyl)piperidine $\left(\mathrm{MeOC}_{2} \mathrm{pip}\right.$, the parent tertiary amine lacking the 3-methyl group). Despite being known, only 30 scant synthetic details had been hitherto reported for this amine. ${ }^{42}$ Further treatment of $\mathrm{MeOC}_{2}$ pip with either methyl trifluoromethanesulfonate or methyl trifluoroethanoate yielded $\left[\mathrm{MeOC}_{2} \mathrm{mpip}\right] \mathrm{X}$ (where $\mathrm{X}^{-}=[\mathrm{OTf}]^{-}$or $\left[\mathrm{CF}_{3} \mathrm{CO}_{2}\right]^{-}$, respectively). To the best of our knowledge, detailed synthetic procedures for 35 these salts are herein reported for the first time.

Alternatively, other simple piperidinium or pyrrolidinium salts were prepared by the reactions of 1-methylpiperidine or 1-methylpyrrolidine with alkylating agents (Scheme 2). As these precursors are commercially available, Scheme 2 represents a 40 simpler synthetic procedure for the preparation of the known ionic liquids $\left[\mathrm{MeOC}_{2} \mathrm{mpyrr}\right]\left[\mathrm{NTf}_{2}\right], \quad\left[\mathrm{MeOC}_{2} \mathrm{OC}_{2} \mathrm{mpyrr}\right]\left[\mathrm{NTf}_{2}\right]$ and $\left[\mathrm{MeOC}_{2}\right.$ mpip] $\left[\mathrm{NTf}_{2}\right]$, as previously described for these or other similar materials. ${ }^{30-32,43}$

\section{NMR analyses}

\section{${ }_{45}$ Free amines}

The tertiary amines derived from 3-methylpiperidine were characterised by means of ${ }^{1} \mathrm{H}$ and ${ }^{13} \mathrm{C}$ NMR spectroscopy. Signals in ${ }^{1} \mathrm{H}$ NMR spectra were assigned based on the cross-peaks in 2D measurements $\left({ }^{1} \mathrm{H}-{ }^{1} \mathrm{H}\right.$ COSY and ${ }^{1} \mathrm{H}^{13} \mathrm{C}$ HMQC); nevertheless, 50 severe overlapping of several signals prevented their complete assignment.

${ }^{1} \mathrm{H}$ NMR data for the five tertiary amines $\left(\mathrm{C}_{4} \mathrm{~m}_{\beta}\right.$ pip, $\mathrm{C}_{6} \mathrm{~m}_{\beta}$ pip, $\mathrm{MeOC}_{2} \mathrm{~m}_{\beta}$ pip, $\mathrm{MeOC}_{2} \mathrm{OC}_{2} \mathrm{~m}_{\beta}$ pip and $\mathrm{MeOC}_{2}$ pip) prepared are listed in the ESI. The ${ }^{1} \mathrm{H}$ NMR spectra of both 3-methylpiperidine 55 and 1,3-dimethylpiperidine have been reported and analysed elsewhere. ${ }^{44}$ Independent signals were observed for hydrogen nuclei on axial or equatorial positions in the piperidine ring. Analysis of chemical shifts and coupling constants (vide infra) revealed that chair conformations with the 3-methyl substituent in 60 equatorial positions (therefore having minimal steric repulsions, see Fig. 1), are predominant, as expected. It should be noted that no indication for boat conformations was found in the NMR data (boat occurrence for the more rigid quaternary ammonium cations is even less likely, as confirmed in the discussion below). ${ }_{65}$ Chemical shifts for equatorial hydrogen nuclei are shifted to higher frequencies than their axial analogues, as usually observed for cyclohexane rings. ${ }^{45}$ For example, multiplets for 2-equatorial and 2-axial protons in $\mathrm{MeOC}_{2} \mathrm{~m}_{\beta}$ pip were found at 2.83-2.92 and $1.56 \mathrm{ppm}$, respectively (see Fig. 2 insets, and ESI). Due to signal 70 overlap, only a few coupling constants could be accurately measured. Their magnitudes follow the known geminal $\approx$ axialaxial $>$ axial-equatorial $\approx$ equatorial-equatorial pattern. ${ }^{46}$ For example, the resonance of the 2-axial hydrogen nucleus of $\mathrm{MeOC}_{2} \mathrm{~m}_{\beta}$ pip (see Fig. 2, right inset) appears as a triplet due to 75 the geminal and axial-axial couplings to the 2-equatorial and 3axial protons, respectively (the observed coupling constant is $10.6 \mathrm{~Hz}$ ). This pattern is also observed for other $\mathrm{Rm}_{\beta}$ pip compounds, and for the derived quaternary cations (vide infra). The signals for the $N$-bonded side groups have been 80 unambiguously assigned by ${ }^{1} \mathrm{H}-{ }^{1} \mathrm{H}$ COSY spectroscopy; the assignment was in accord with the previously studied azepane derivatives. ${ }^{38}$ The ${ }^{13} \mathrm{C}$ NMR data for the four tertiary $\mathrm{Rm}_{\beta}$ pip are collected in the ESI. Each individual signal has been assigned to the specific carbon nuclei from the cross-peaks found in the 2D ${ }_{85}{ }^{1} \mathrm{H}-{ }^{13} \mathrm{C} \mathrm{HMQC}$ spectra (once ${ }^{1} \mathrm{H}$ signal assignments were known).

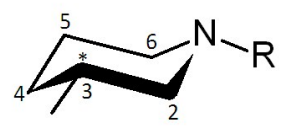

Fig. 1 The structure of (3R)-1-R-3-methylpipiridine $\left(\mathrm{Rm}_{\beta}\right.$ pip) with ring numbering; the stereogenic centre is marked with an asterisk; the 3-methyl substituent is depicted as occupying an equatorial position, as suggested by ${ }^{1} \mathrm{H}$ NMR data.

\section{Ionic liquids}

The ${ }^{1} \mathrm{H}$ NMR spectra of $\left[\mathrm{Rmm}_{\beta} \mathrm{pip}\right]^{+}$salts show even more complex patterns than their precursor amines, since a second chiral centre has been introduced into the cation. This increases 
the number of isomers of the cation and, hence, the number of signals and the complexity of their multiplicities (see, for example, the spectrum of $\left[\mathrm{MeOC}_{2} \mathrm{~mm}_{\beta}\right.$ pip][OTf] in Fig. 3, and all data in the ESI). Although overlapping of the ${ }^{1} \mathrm{H}$ signals 5 prevented complete assignments, some of them were unambiguously identified by means of ${ }^{1} \mathrm{H}-{ }^{1} \mathrm{H}$ COSY measurements and the analysis of their coupling patterns (comparison with data for the neutral amine derivatives was also useful and supportive). In most cases, certain signals were 10 observed as duplicated sets over two clearly distinguishable frequencies (or frequency ranges), each having different intensities (Fig 3, inset). The reason for this is the presence of spectroscopically non-equivalent sets of isomers, i.e. pairs of diastereomers (see Fig. 4). This is supported by the ${ }^{13} \mathrm{C} N M R$ 15 spectra of the salts, which are composed of two sets of signals with different relative intensities (see Fig. 3). For example, two different signals are observed for the 2-axial hydrogen nuclei of $\left[\mathrm{MeOC}_{2} \mathrm{~mm}_{\beta}\right.$ pip][OTf] (see Fig. 3 and ESI), both being triplets due to coupling to the 2-equatorial and 3-axial protons.

20 There are four possible diastereomers (two pairs of enantiomers, $1 S, 3 R ; 1 R, 3 S$ and $1 R, 3 R ; 1 S, 3 S)$ for each $\left[R m_{\beta}\right.$ pip $] \mathrm{X}$ salt, as depicted in Fig. 4 . The precursor tertiary amines preferentially occur in chair conformations with $\mathrm{R}$ chains in equatorial positions, as depicted in Fig. 1. Therefore, 25 methylation products with axial NMe groups, i.e. $1 S, 3 R$ and $1 R, 3 S$, should be predominant. The other diastereomers, $1 R, 3 R$ and $1 S, 3 S$, would be formed by reaction of chair conformers with either axial 3-methyl and equatorial $\mathrm{R}$ or with equatorial 3-methyl and axial $\mathrm{R}$, both being presumably less abundant due to more 30 intense repulsions between ring substituents. Therefore,
$\left[\mathrm{Rmm}_{\beta}\right.$ pip]X ionic liquids are expected to be mixtures of diastereomers richer in $1 S, 3 R ; 1 R, 3 S$ than in $1 R, 3 R ; 1 S, 3 S$ (empirically $72: 28 \%$, respectively, in the case of $\left.\left[\mathrm{MeOC}_{2} \mathrm{~mm}_{\beta} \mathrm{pip}\right][\mathrm{OTf}]\right)$. This is further supported by the ${ }^{1} \mathrm{H}$ and ${ }_{35}^{13} \mathrm{C}$ chemical shifts of the NMe groups. The signals for nuclei in axial positions are significantly shifted to low frequencies as compared to those for equatorial, due to shielding or deshielding, respectively, caused by the magnetic anisotropy of ring bonds, an effect commonly observed for chair conformations. ${ }^{47}$ As seen in ${ }_{40}$ Fig 3, the resonances for axial NMe are noticeably more intense than those for equatorial NMe.

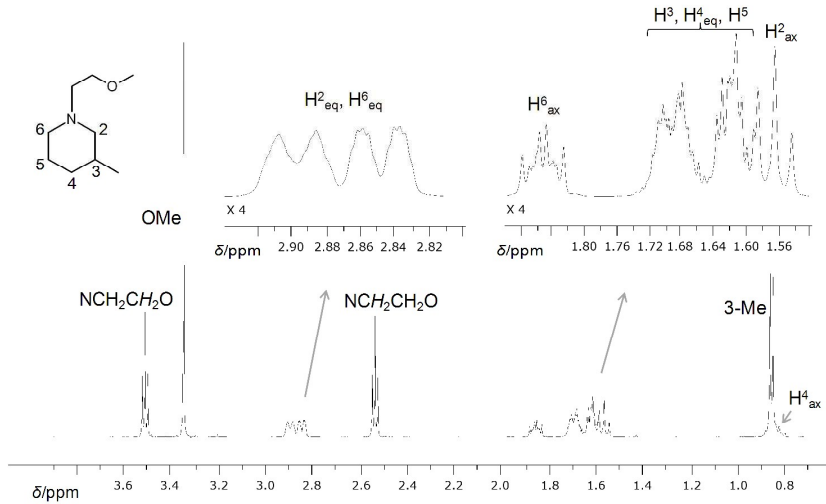

Fig. 2 The ${ }^{1} \mathrm{H}$ NMR spectrum $\left(500.13 \mathrm{MHz}, 25^{\circ} \mathrm{C}, \mathrm{CDCl}_{3}\right)$ of $\mathrm{MeOC}_{2} \mathrm{~m}_{\beta}$ pip. Insets: expansions of the signals for the $\mathrm{H}^{6}{ }_{\mathrm{eq}}$ and $\mathrm{H}^{2}$ eq (left) 45 or $\mathrm{H}_{\mathrm{ax}}^{6}, \mathrm{H}^{3}, \mathrm{H}^{4}{ }_{\mathrm{eq}}, \mathrm{H}^{5}$ and $\mathrm{H}_{\text {ax }}^{2}$ (right) hydrogen nuclei; $\mathrm{H}_{\mathrm{eq}}^{n}$ or $\mathrm{H}_{\mathrm{ax}}^{n}$ represent nuclei in equatorial or axial positions bonded to the $\mathrm{C}^{n}$ atom, respectively. Axial and equatorial hydrogen atoms at the $n$ position are abbreviated as $\mathrm{H}_{\text {ax }}^{n}$ and $\mathrm{H}_{\text {eq }}^{n}$, respectively.

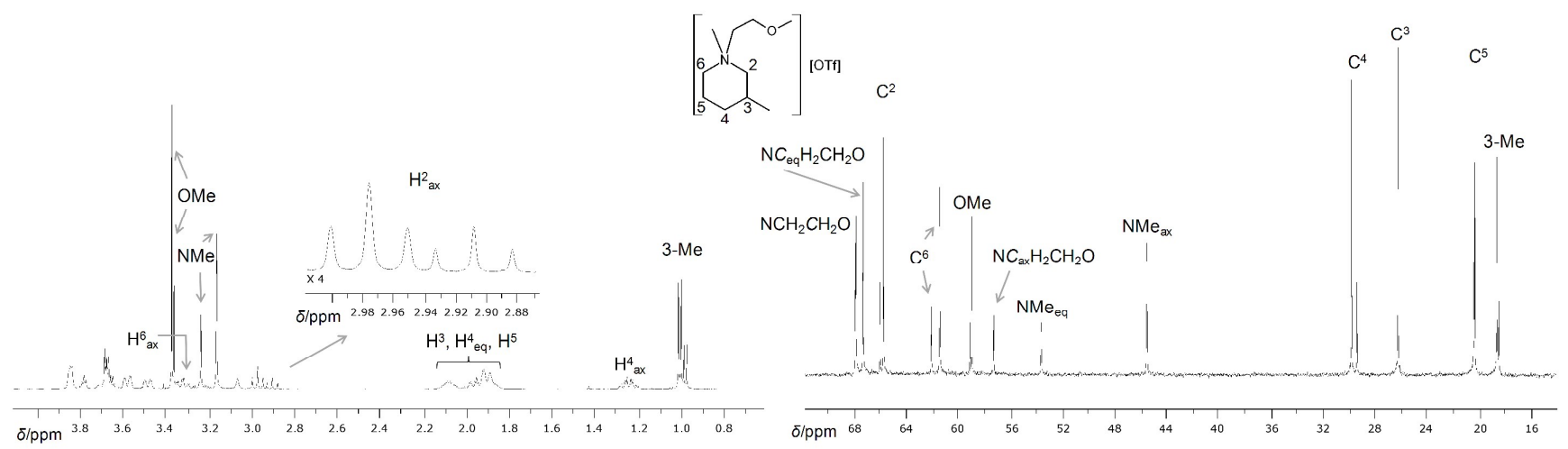

${ }_{50}$ Fig. 3 The ${ }^{1} \mathrm{H}$ (left, $500.13 \mathrm{MHz}, 25^{\circ} \mathrm{C}, \mathrm{CDCl}_{3}$ ) and ${ }^{13} \mathrm{C}$ (right, $125.76 \mathrm{MHz}, 25^{\circ} \mathrm{C}, \mathrm{CDCl}_{3}$ ) NMR spectra of [ $\mathrm{MeOC}_{2} \mathrm{~mm}_{\beta}$ pip] [OTf]. Signal duplication is clear for some resonances, such as 3-Me, $\mathrm{H}_{\text {ax }}^{2}$, OMe $\left({ }^{1} \mathrm{H}\right)$, $\mathrm{NMe}\left({ }^{1} \mathrm{H}\right.$ and $\left.{ }^{13} \mathrm{C}\right)$ or $\mathrm{NCH}_{2} \mathrm{CH}_{2} \mathrm{O}\left({ }^{13} \mathrm{C}\right)$. Inset $\left({ }^{1} \mathrm{H}\right)$ : expansion of the two triplets found for the $\mathrm{H}^{2}$ ax hydrogen nuclei; the relative intensity is 72:28. Axial and equatorial hydrogen atoms at the $n$ position are abbreviated as $\mathrm{H}_{\text {ax }}^{n}$ and $\mathrm{H}^{n}{ }_{\text {eq }}$, respectively.

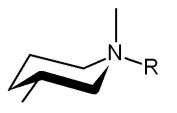

$1 S, 3 R$

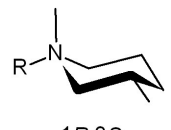

$1 R, 3 S$

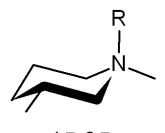

$1 R, 3 R$

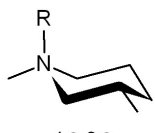

$1 S, 3 S$

Fig. 4 Structures of the possible diastereomers of $\left[\mathrm{Rmm}_{\beta} \mathrm{pip}\right]^{+}$.

55 Thus, the $\left[\mathrm{Rmm}_{\beta} \mathrm{pip}\right] \mathrm{X}$ ionic liquids are mixtures of isomers. Their physical properties, as measured experimentally, represent those of these diastereomeric mixtures. Only in the case of $\left[(1 S, 3 R)-\mathrm{C}_{6} \mathrm{~mm}_{\beta} \mathrm{pip}\right]_{0.5}\left[(1 R, 3 S)-\mathrm{C}_{6} \mathrm{~mm}_{\beta} \mathrm{pip}\right]_{0.5}\left[\mathrm{BPh}_{4}\right]$, which was isolated by crystallisation, was a pure racemic mixture obtained,

60 and its crystal structure determined (vide infra).

The ${ }^{1} \mathrm{H}$ NMR data reveal trends for some chemical shifts as a function of the counteranion of the salts. When considering hydrogen nuclei in close proximity to the nitrogen atom, deshielding of the related resonances increases in the order ${ }_{65}\left[\mathrm{NTf}_{2}\right]^{-}<[\mathrm{OTf}]^{-}<\left[\mathrm{CF}_{3} \mathrm{CO}_{2}\right]^{-}<\mathrm{I}^{-}$. For example, the chemical shifts of the equatorial NMe hydrogen nuclei in $\left[\mathrm{C}_{6} \mathrm{~mm}_{\beta}\right.$ pip $] \mathrm{X}$ are $3.05,3.16,3.27$ and 3.44 for $\mathrm{X}^{-}=\left[\mathrm{NTf}_{2}\right]^{-}$, [OTf $]^{-},\left[\mathrm{CF}_{3} \mathrm{CO}_{2}\right]^{-}$ and $\mathrm{I}^{-}$, respectively (see ESI), due to the increasing hydrogen bonding ability of those anions. This reflects the relative acidity 70 of these protons, as also reported for azepanium ionic liquids. ${ }^{38}$ 
Table 1 Crystal and refinement data; estimated standard deviations are included in parentheses

\begin{tabular}{|c|c|c|c|c|}
\hline & {$\left[\mathrm{C}_{6} \mathrm{~mm}_{\beta} \mathrm{pip}\right]\left[\mathrm{BPh}_{4}\right]$} & {$\left[\mathrm{C}_{4} \mathrm{Hm}_{\beta}\right.$ pip $] \mathrm{Br}$} & {$\left[\mathrm{MeOC}_{2}\right.$ mpip $] \mathrm{Cl}$} & {$\left[\mathrm{MeOC}_{2} \mathrm{mpyrr}\right] \mathrm{Br}$} \\
\hline Chemical formula & $\mathrm{C}_{37} \mathrm{H}_{48} \mathrm{NB}$ & $\mathrm{C}_{10} \mathrm{H}_{22} \mathrm{NBr}$ & $\mathrm{C}_{9} \mathrm{H}_{20} \mathrm{NOCl}$ & $\mathrm{C}_{8} \mathrm{H}_{18} \mathrm{NOBr}$ \\
\hline Formula weight $/ \mathrm{g} \mathrm{mol}^{-1}$ & 517.57 & 236.20 & 197.57 & 224.14 \\
\hline Crystal system & Monoclinic & Monoclinic & Orthorhombic & Orthorhombic \\
\hline Space group & $P 2_{1} / c$ & $C 2 / c$ & Pbcn & $P 2_{1} 2_{1} 2_{1}$ \\
\hline$a / \AA ̊$ & $10.0226(4)$ & $18.3719(11)$ & $15.6856(5)$ & $6.6837(3)$ \\
\hline$b / \AA ̊$ & $18.6901(8)$ & $19.4893(11)$ & $13.8762(4)$ & $11.3299(8)$ \\
\hline$c / \AA ̊$ & $17.0143(7)$ & $7.3743(4)$ & $9.7497(2)$ & $13.3205(10)$ \\
\hline$\alpha /^{\circ}$ & 90.00 & 90.00 & 90.00 & 90.00 \\
\hline$\beta /^{\circ}$ & $103.575(2)$ & $112.495(4)$ & 90.00 & 90.00 \\
\hline$\gamma /{ }^{\circ}$ & 90.00 & 90.00 & 90.00 & 90.00 \\
\hline$V / \AA^{3}$ & $3098.1(2)$ & $2439.4(2)$ & $2122.09(10)$ & $1008.70(11)$ \\
\hline$Z$ & 4 & 8 & 8 & 4 \\
\hline$D_{\mathrm{c}} / \mathrm{g} \mathrm{cm}^{-3}$ & 1.110 & 1.286 & 1.213 & 1.476 \\
\hline$\mu / \mathrm{mm}^{-1}$ & 0.062 & 3.328 & 0.323 & 4.027 \\
\hline$F(000)$ & 1128 & 992 & 848 & 464 \\
\hline$T / \mathrm{K}$ & $150(2)$ & $273(2)$ & $293(2)$ & $120(2)$ \\
\hline$\theta_{\min , \max } /^{\circ}$ & $3.02,20.82$ & $2.95,27.59$ & $2.94,27.53$ & $3.06,27.48$ \\
\hline Reflections measured & 15850 & 24801 & 24516 & 8310 \\
\hline Independent reflections & 3196 & 2830 & 2433 & 2299 \\
\hline$R_{\text {int }}$ & 0.0562 & 0.0899 & 0.0647 & 0.0608 \\
\hline Observed data $[I>2 \sigma(I)]$ & 2791 & 1873 & 1854 & 1996 \\
\hline No. parameters & 353 & 111 & 177 & 102 \\
\hline$R_{1}$ & 0.1238 & 0.0692 & 0.0744 & 0.0375 \\
\hline$w R\left(F^{2}\right)$ & $0.3423^{a, e}$ & $0.1539^{b, e}$ & $0.1703^{c, e}$ & $0.0698^{d, e}$ \\
\hline$S$ & 1.129 & 1.052 & 1.084 & 1.049 \\
\hline CCDC ref. no. & 1028636 & 1028633 & 1028635 & 1028634 \\
\hline
\end{tabular}

\section{Crystal structures}

5 The crystal structures of $\left[\mathrm{C}_{6} \mathrm{~mm}_{\beta}\right.$ pip $]\left[\mathrm{BPh}_{4}\right],\left[\mathrm{C}_{4} \mathrm{Hm}_{\beta} \mathrm{pip}\right] \mathrm{Br}$, $\left[\mathrm{MeOC}_{2} \mathrm{mpip}\right] \mathrm{Cl}$ and $\left[\mathrm{MeOC}_{2} \mathrm{mpyrr}\right] \mathrm{Br}$ were determined by single crystal X-ray diffraction. Crystal and refinement details are listed in Table 1.

Single crystal growth of a number of salts based on 10 3-methylpiperidinium cations was unsuccessful. This may be linked to the occurrence of the four possible cation diastereomers, as discussed in the NMR section above, and/or to ring conformational flexibility, both phenomena presumably being responsible for restricted nucleation. Therefore, a 15 tetraphenylborate salt $\left(\left[\mathrm{C}_{6} \mathrm{~mm}_{\beta} \mathrm{pip}\right]\left[\mathrm{BPh}_{4}\right]\right)$ was prepared, expecting that the bulky, rigid and aromatic characteristics of its anion would favour crystallisation by dominating short-range interactions. Indeed, $\left[\mathrm{C}_{6} \mathrm{~mm}_{\beta} \mathrm{pip}\right]\left[\mathrm{BPh}_{4}\right]$ single crystals were obtained and the structure was solved in a $P 2_{1} / c$ monoclinic 20 lattice. The asymmetric unit consists of one ion pair. Unit cells built up by the symmetry operations of the $P 2_{1} / c$ space group contain four ion pairs, where the cations are $1 R, 3 S$ and $1 S, 3 R$ diastereomers. Therefore, the crystallised material is a racemic mixture of one of the two possible pairs of enantiomers, as seen

25 in Fig. 5. According to the NMR data above, those diastereomers would be predominant in all $\left[\mathrm{Rmm}_{\beta} \text { pip }\right]^{+}$salts. Thus, it is not surprising that $\left[1 S, 3 R-\mathrm{C}_{6} \mathrm{~mm}_{\beta} \mathrm{pip}\right]_{0.5}\left[1 R, 3 S-\mathrm{C}_{6} \mathrm{~mm}_{\beta} \mathrm{pip}\right]_{0.5}\left[\mathrm{BPh}_{4}\right]$ was crystallised and its structure determined (albeit the existence of crystals containing the other two diastereomers, $1 R, 3 R$ and $301 S, 3 S$, cannot be ruled out). The ring cores adopt chair conformations, as observed in solution by NMR spectroscopy (see above). Furthermore, the 3-methyl and N-hexyl groups lie in equatorial positions, whereas the $\mathrm{N}-\mathrm{Me}$ groups lie in axial positions (also consistent with NMR data, vide supra), thus
35 minimising the steric repulsions of ring substituents.

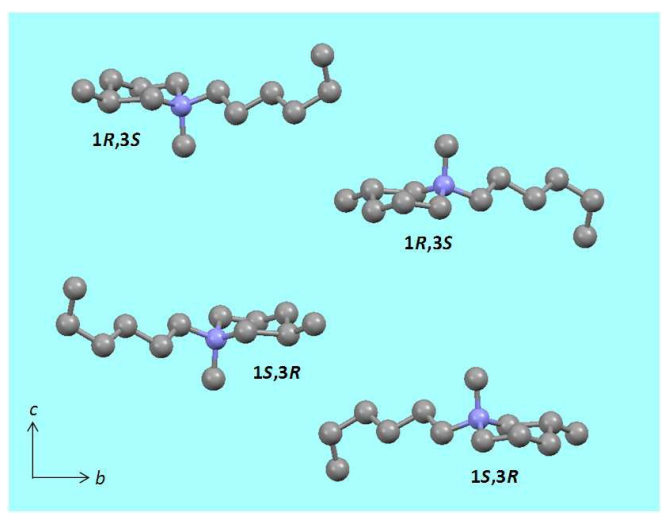

Fig. 5 A view of the four cations contained in a unit cell of $\left[\mathrm{C}_{6} \mathrm{~mm}_{\beta}\right.$ pip $]\left[\mathrm{BPh}_{4}\right]$. Two pairs of cation enantiomers occur, demonstrating that a racemic mixture had crystallised. Grey $=$ carbon; blue $=$ nitrogen. 40 Hydrogen atoms are omitted for clarity.

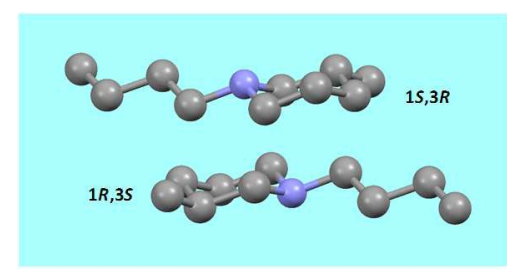

Fig. 6 A view of two enantiomeric cations in the structure of $\left[\mathrm{C}_{4} \mathrm{Hm}_{\beta}\right.$ pip $] \mathrm{Br}$. Grey = carbon; blue $=$ nitrogen. Hydrogen atoms are omitted for clarity.

45 The crystal structure of $\left[\mathrm{C}_{4} \mathrm{Hm}_{\beta}\right.$ pip $] \mathrm{Br}$, refined as a monoclinic $C 2 / c$ lattice, also contains a racemic mixture of $1 R, 3 S$ and $1 S, 3 R$ enantiomers. The cationic cores adopt chair conformations, as seen in Fig. 6, where both 3-methyl and N-butyl substituents 
occupy equatorial positions.

In addition to the 3-methylpiperidinium structures described above, those of $\left[\mathrm{MeOC}_{2}\right.$ mpip] $\mathrm{Cl}$ and $\left[\mathrm{MeOC}_{2}\right.$ mpyrr] $\mathrm{Br}$ were also determined. Ring and N-Me cation atoms in the asymmetric unit 5 of the crystal structure of $\left[\mathrm{MeOC}_{2} \mathrm{mpip}\right] \mathrm{Cl}$ are disordered over two chair conformations (see below); despite the severe disorder, the structure could be refined with acceptable success in a $\mathrm{Pbcn}$ orthorhombic lattice. The salt $\left[\mathrm{MeOC}_{2} \mathrm{mpyrr}\right] \mathrm{Br}$ crystallised in a $P 2{ }_{1} 2_{1} 2_{1}$ lattice.

10 The $\left[\mathrm{C}_{6} \mathrm{~mm}_{\beta}\right.$ pip $]\left[\mathrm{BPh}_{4}\right]$ crystal structure is, to the best of our knowledge, the first one reported for a quaternary 3-methylpiperidium salt. Nevertheless, structures of two tertiary and two secondary derivatives are known. In the case of tertiary (monoprotonated) salts, the chiral $\left[1 R, 3 S-\mathrm{C}_{2} \mathrm{Hm} \mathrm{p}_{\beta} \mathrm{pip}\right] \mathrm{Cl}$ 15 (synthesised by asymmetric hydrogenation of a 3-methylpyridine derivative; $\mathrm{C}_{2}=$ ethyl) crystallised in the non-centrosymmetric $P 22_{1} 2_{1}$ space group, ${ }^{48}$ whereas the structure of a racemic zwitterionic 3-methylpiperidinium N-bisphosphonate was solved as a centrosymmetric $P 2_{1} / n$ lattice, ${ }^{49}$ which (similar to ${ }_{20}\left[\mathrm{C}_{4} \mathrm{Hm}_{\beta}\right.$ pip] $\mathrm{Br}$ and $\left[\mathrm{C}_{6} \mathrm{~mm}_{\beta}\right.$ pip $\left.]\left[\mathrm{BPh}_{4}\right]\right)$ is composed of both $1 R, 3 S$ and $1 S, 3 R$ enantiomers. Crystal structures of the bromide ${ }^{50}$ and naphthalene-1,5-disulfonate ${ }^{51}$ salts of the secondary $\left[\mathrm{H}_{2} \mathrm{~m}_{\beta} \text { pip }\right]^{+}$cation have been recently reported; both were solved as centrosymmetric lattices, thus containing racemic mixtures.

${ }_{25}$ Chair cation conformations with equatorial 3-methyl and $\mathrm{N}$-substituents occur in the previously reported structures, as observed for the new 3-methylpiperidinium examples in this work. In addition, classical chair conformations are also observed in the crystal structure of $\left[\mathrm{MeOC}_{2} \mathrm{mpip}\right] \mathrm{Cl}$, as illustrated in ${ }_{30}$ Fig. 7(a), a fact which is common to other piperidinium salts, ${ }^{52}$ as expected for the much higher stability of such conformations as compared to the boat or twist counterparts.

Relevant cationic core bond distances and angles for the structures reported here $\left(\left[\mathrm{C}_{6} \mathrm{~mm}_{\beta}\right.\right.$ pip $]\left[\mathrm{BPh}_{4}\right],\left[\mathrm{C}_{4} \mathrm{Hm}_{\beta}\right.$ pip $] \mathrm{Br}$, $35\left[\mathrm{MeOC}_{2} \mathrm{mpip}\right] \mathrm{Cl}$ and $\left.\left[\mathrm{MeOC}_{2} \mathrm{mpyrr}\right] \mathrm{Br}\right)$, and for known related piperidinium or pyrrolidinium salts, are listed in Table 2. For the piperidinium (both 3-methyl- or $C$-unsubstituted) structures determined here, average ring distances fall in the 1.47-1.54 $\AA$ range, with no significant difference (within experimental error) 40 between different salts or different bonds, in good agreement with previously reported piperidinium crystals, ${ }^{52}$ with the exception of $\left[\mathrm{C}_{6} \mathrm{~mm}_{\beta}\right.$ pip $]\left[\mathrm{BPh}_{4}\right]$. Noticeably dissimilar distances are observed for the latter (1.43-1.69 $\AA$, see Table 2), maybe as a result of either high ring strain or uncertainty in the diffraction data. Ring 45 angles for the newly determined piperidinium structures are also similar (109-113 ${ }^{\circ}$, see Table 2 ) to those previously reported. ${ }^{52}$ Again, data for $\left[\mathrm{C}_{6} \mathrm{~mm}_{\beta}\right.$ pip $]\left[\mathrm{BPh}_{4}\right]$ fall in a much wider range (106-121 ${ }^{\circ}$ ).

Ring distances for $\left[\mathrm{MeOC}_{2} \mathrm{mpyrr}\right] \mathrm{Br}$ are in good agreement 50 with those of known pyrrolidinium salts ${ }^{53}(1.51-1.55 \AA$ and 1.46-1.56 $\AA$, respectively, see Table 2). The $\mathrm{C}_{\alpha}-\mathrm{N}-\mathrm{C}_{\alpha}$ angle $\left(102.1^{\circ}\right)$ for $\left[\mathrm{MeOC}_{2}\right.$ mpyrr] Br is noticeably smaller than $\mathrm{N}-\mathrm{C}_{\alpha^{-}}$ $\mathrm{C}_{\beta}$ or $\mathrm{C}_{\alpha}-\mathrm{C}_{\beta}-\mathrm{C}_{\beta}\left(>104^{\circ}\right)$, whilst all fall within the usual values for pyrrolidinium salt crystals $\left(101-109^{\circ}\right)$. The ring adopts a 55 near-envelope conformation where the $\mathrm{C}_{\alpha}-\mathrm{C}_{\beta}-\mathrm{C}_{\beta}-\mathrm{C}_{\alpha}$ torsion angle is $4.9^{\circ}$ and the nitrogen atom occupies the flap position, as seen in Fig. 7(b). Such a conformation is usual for pyrrolidinium rings, observed in $c a .30 \%$ of all known crystals. ${ }^{53}$ The N-methyl and 2- methoxyethyl groups lie on the axial and equatorial positions, ${ }_{60}$ respectively. It should be noted that, including all previously published structures, bond distances and ring angles span across wider distributions for pyrrolidinium as compared to piperidinium. This fact may be due to the much larger number of stable conformers for the former (ten envelope and ten half-chair 65 conformations of similar energy minima) than for the latter (only two chair conformations, much more stable than any of the other local energy minima, such as boat). ${ }^{47}$

Table 2 Average bond distances and angles for the rings in the crystal structures of $\left[\mathrm{C}_{6} \mathrm{~mm}_{\beta}\right.$ pip $]\left[\mathrm{BPh}_{4}\right],\left[\mathrm{C}_{4} \mathrm{Hm} \mathrm{m}_{\beta}\right.$ pip $] \mathrm{Br}$, $\left[\mathrm{MeOC}_{2} \mathrm{mpip}\right] \mathrm{Cl}$ and $70\left[\mathrm{MeOC}_{2} \mathrm{mpyrr}\right] \mathrm{Br}$; data for previously reported ${ }^{a}$ related

3-methylpiperidinium, piperidinium and pyrrolidinium crystals are also included for comparison; standard deviations are included in parentheses

3-methylpiperidinium

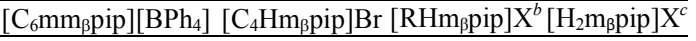

\begin{tabular}{|c|c|c|c|c|}
\hline & \multicolumn{4}{|c|}{$\mathrm{N}-\mathrm{C}_{\alpha}$} \\
\hline $\mathrm{N}-\mathrm{C}^{2} / \AA$ & $\overline{1.44(1)}$ & $1.500(7)$ & $1.499(7)$ & $1.475(2)$ \\
\hline \multirow[t]{2}{*}{$\mathrm{C}^{6}-\mathrm{N} / \AA$} & $1.56(1)$ & $1.48(1)$ & $1.50(1)$ & $1.482(9)$ \\
\hline & \multicolumn{4}{|c|}{$\mathrm{C}_{\alpha}-\mathrm{C}_{\beta}$} \\
\hline$C^{2}-C^{3} / \AA$ & $\overline{1.67(2)}$ & $1.53(1)$ & $1.52(1)$ & $1.513(1)$ \\
\hline \multirow[t]{2}{*}{$C^{5}-C^{6} / \AA$} & $1.45(2)$ & $1.48(1)$ & $1.519(7)$ & $1.504(5)$ \\
\hline & \multicolumn{4}{|c|}{$\mathrm{C}_{\beta}-\mathrm{C}_{\gamma}$} \\
\hline$C^{3}-C^{4} / \AA$ & $\overline{1.49(1)}$ & $1.49(1)$ & $1.524(9)$ & $1.508(6)$ \\
\hline \multirow[t]{2}{*}{$C^{4}-C^{5} / \AA$} & $1.46(1)$ & $1.509(8)$ & $1.521(2)$ & $1.517(8)$ \\
\hline & \multicolumn{4}{|c|}{$\mathrm{C}_{\alpha}-\mathrm{N}-\mathrm{C}_{\alpha}$} \\
\hline \multirow[t]{2}{*}{$\mathrm{C}^{6}-\mathrm{N}-\mathrm{C}^{2} / 0$} & $\overline{114.4(7)}$ & $110.6(5)$ & $110.6(7)$ & $112.5(7)$ \\
\hline & \multicolumn{4}{|c|}{$\mathrm{N}-\mathrm{C}_{\alpha}-\mathrm{C}_{\beta}$} \\
\hline $\mathrm{N}-\mathrm{C}^{2}-\mathrm{C}^{3} / 0$ & $\overline{111.4(8)}$ & $112.2(6)$ & $111.33(9)$ & $111.4(5)$ \\
\hline \multirow[t]{2}{*}{$\mathrm{C}^{5}-\mathrm{C}^{6}-\mathrm{N} /{ }^{\circ}$} & $113.8(8)$ & $111.7(6)$ & $110(1)$ & $109.6(9)$ \\
\hline & \multicolumn{4}{|c|}{$\mathrm{C}_{\alpha}-\mathrm{C}_{\beta}-\mathrm{C}_{\gamma}$} \\
\hline$C^{2}-C^{3}-C^{4} / 0$ & $107.2(8)$ & $109.7(6)$ & $110.5(6)$ & $109.7(7)$ \\
\hline \multirow[t]{2}{*}{$C^{4}-C^{5}-C^{6} / 0$} & $109.3(9)$ & $110.5(7)$ & 111(1) & $110.89(6)$ \\
\hline & \multicolumn{4}{|c|}{$\mathrm{C}_{\beta}-\mathrm{C}_{\gamma}-\mathrm{C}_{\beta}$} \\
\hline \multirow[t]{3}{*}{$C^{3}-C^{4}-C^{5} / 0$} & $119.7(8)$ & $111.2(6)$ & $111.2(7)$ & $111(1)$ \\
\hline & \\
\hline & \multicolumn{4}{|c|}{$\frac{\text { piperidinium }}{\left[\mathrm{R}_{b} \mathrm{R}_{b} \mathrm{pip}\right] \mathrm{X}^{d, e}}$} \\
\hline $\mathrm{N}-\mathrm{C}_{\alpha} / \AA$ & $1.520(8)$ & \multicolumn{3}{|c|}{$1.50(2)$} \\
\hline $\mathrm{C}_{\alpha}-\mathrm{C}_{\beta} / \AA$ & $1.50(2)$ & \multicolumn{3}{|c|}{$1.51(4)$} \\
\hline $\mathrm{C}_{\beta}-\mathrm{C}_{\gamma} / \AA$ & $1.53(4)$ & \multicolumn{3}{|c|}{$1.51(2)$} \\
\hline $\mathrm{C}_{\alpha}-\mathrm{N}-\mathrm{C}_{\alpha} /{ }^{\circ}$ & $109(1)$ & \multicolumn{3}{|c|}{$111(2)$} \\
\hline $\mathrm{N}-\mathrm{C}_{\alpha}-\mathrm{C}_{\beta} /{ }^{\circ}$ & $112.9(7)$ & \multicolumn{3}{|c|}{$111(2)$} \\
\hline $\mathrm{C}_{\alpha}-\mathrm{C}_{\beta}-\mathrm{C}_{\gamma} /^{\circ}$ & $111(1)$ & \multicolumn{3}{|c|}{$111(2)$} \\
\hline \multirow[t]{3}{*}{$\mathrm{C}_{\beta}-\mathrm{C}_{\gamma}-\mathrm{C}_{\beta} /{ }^{\circ}$} & $110(2)$ & \multicolumn{3}{|c|}{$110(1)$} \\
\hline & \multicolumn{4}{|c|}{ pyrrolidinium } \\
\hline & {$\left[\mathrm{MeOC}_{2} \mathrm{mpyrr}\right] \mathrm{Br}$} & & {$\left[\mathrm{R}_{a} \mathrm{R}_{b}\right.$ pyrr $]$} & \\
\hline $\mathrm{N}-\mathrm{C}_{\alpha} / \AA$ & $1.518(2)$ & & $1.50(3)$ & \\
\hline $\mathrm{C}_{\alpha}-\mathrm{C}_{\beta} / \AA$ & $1.52(1)$ & & $1.50(4)$ & \\
\hline $\mathrm{C}_{\beta}-\mathrm{C}_{\beta} / \AA$ & 1.548 & & $1.51(5)$ & \\
\hline $\mathrm{C}_{\alpha}-\mathrm{N}-\mathrm{C}_{\alpha} /^{\circ}$ & 101.9 & & $104(3)$ & \\
\hline $\mathrm{N}-\mathrm{C}_{\alpha}-\mathrm{C}_{\beta} /{ }^{\circ}$ & $104.7(6)$ & & $105(2)$ & \\
\hline $\mathrm{C}_{\alpha}-\mathrm{C}_{\beta}-\mathrm{C}_{\beta} /{ }^{\circ}$ & $105.4(3)$ & & $106(3)$ & \\
\hline
\end{tabular}

${ }^{a}$ Data retrieved from the CSD; referred to by their six-letter codes for 3-methylpiperidinium salts. ${ }^{b}\left[\mathrm{RHm}_{\beta} \text { pip }\right]^{+}$represent tertiary 75 3-methylpiperidinium cations; \#BEWVOP (ref. ${ }^{48}$ ), \#LAPDUC (ref. ${ }^{49}$ ).

${ }^{c}\left[\mathrm{H}_{2} \mathrm{~m}_{\beta} \text { pip }\right]^{+}$represent secondary 3-methylpiperidinium cations; \#PAVLIJ $\left(\right.$ ref. $\left.{ }^{50}\right)$, \#PAVSAI $\left(\right.$ ref. ${ }^{51}$ ). ${ }^{d}$ Data for known piperidinium salts (ref. ${ }^{52}$ ).

${ }^{e} \mathrm{R}_{a}$ and $\mathrm{R}_{b}$ denote any $\mathrm{N}$-substituents bonded through a non-metal atom. ${ }^{f}$ Data for known pyrrolidinium salts (ref. ${ }^{53}$ ).

80 Further examination of the $\left[\mathrm{C}_{6} \mathrm{~mm}_{\beta}\right.$ pip $]\left[\mathrm{BPh}_{4}\right]$ structure revealed that the terminal methyl group in the hexyl side chain is in a gauche conformation, i.e. the bond between the fourth and fifth carbon atoms in the chain shows a pronounced torsion (dihedral angle $=68.0^{\circ}$; see Fig. 5) away from the otherwise 85 all-anti conformation. This conformation AAAG, in the notation 
of Berg and co-workers, ${ }^{54}$ is similar to that found for $\left[\mathrm{C}_{6}\right.$ mazp $]\left[\mathrm{NTf}_{2}\right]$. $^{38}$

The ether-functionalised chains in both $\left[\mathrm{MeOC}_{2} \mathrm{mpip}\right] \mathrm{Cl}$ and $\left[\mathrm{MeOC}_{2} \mathrm{mpyrr}\right] \mathrm{Br}$ lie in bent conformations (N-C-C-O dihedral 5 angles are 73.6 and $71.4^{\circ}$, respectively, see Fig. 7). In $\left[\mathrm{MeOC}_{2} \mathrm{mpip}\right] \mathrm{Cl}$, the oxygen atom establishes a close intramolecular contact with $\mathrm{C}-\mathrm{H}$ in $\alpha$ positions to the nitrogen atom, i.e. the $\mathrm{C}^{2}$ position in the ring, for both disordered cation conformations. The involved $\mathrm{H} \cdots \mathrm{O}$ and $\mathrm{C} \cdots \mathrm{O}$ average distances 10 are 2.55 and $3.10 \AA$. Therefore, it seems that the 2-methoxyethyl chain has a clear tendency to bend back and hydrogen-bond to methylene groups adjacent to nitrogen. An inspection of the $\left[\mathrm{MeOC}_{2}\right.$ mpyrr]Br structure reveals that the 2-methoxyethyl side-chains lie in bent comformations, so that the oxygen atom is 15 in close proximity to the NMe moiety (see below). The measured $\mathrm{H} \cdots \mathrm{O}$ (involving the closest hydrogen atom, albeit its position uncertainty may be large) and $\mathrm{C} \cdots \mathrm{O}$ distances are 2.30 and $2.94 \AA$, well below the sum of van der Waals radii (2.72 and $3.22 \AA),{ }^{55}$ thus indicating that a noticeable intramolecular 20 interaction is likely influencing the cation structure, as observed above for $\left[\mathrm{MeOC}_{2} \mathrm{mpip}\right] \mathrm{Cl}$. Therefore, the ether functionality induces a strong degree of intramolecular hydrogen-bonding which may have implications for the physical properties of the salts (vide infra).
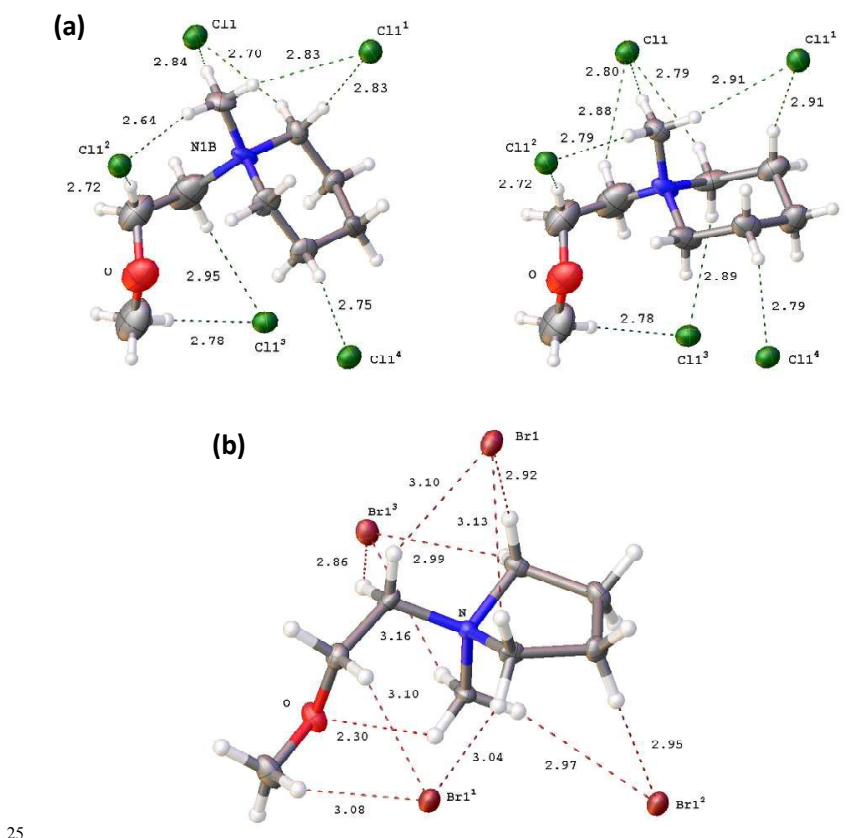

Fig. 7 Perspectives of anion coordination around the cations in the crystal structures of (a) $\left[\mathrm{MeOC}_{2} \mathrm{mpip}\right] \mathrm{Cl}$ and (b) $\left[\mathrm{MeOC}_{2} \mathrm{mpyrr}\right] \mathrm{Br}$. Note the two cation conformers for $\left[\mathrm{MeOC}_{2} \mathrm{mpip}\right] \mathrm{Cl}$, which involve disordered ring and $\mathrm{N}-\mathrm{Me}$ atoms yet identical 2-methoxyethyl positions. Dotted dark red

30 lines indicate selected $\mathrm{H}^{\cdots}$ anion contacts; distances $(\AA)$ are given in black. White $=$ hydrogen; grey $=$ carbon; blue $=$ nitrogen; red $=$ oxygen; green $=$ chlorine; crimson $=$ bromine .

In order to evaluate the significance of the anion-cation hydrogen-bonding in the structures, average intermolecular $\mathrm{H} \cdots \mathrm{X}$ 35 contacts $(\mathrm{X}=\mathrm{C}, \mathrm{Br}$ or $\mathrm{Cl})$ were measured below the sum of the conventional van der Waals radii $(2.90,3.05$ and $2.96 \AA$, respectively). ${ }^{55,56}$ These distances for the quaternary ammonium salt $\left(\left[\mathrm{C}_{6} \mathrm{~mm}_{\beta}\right.\right.$ pip $]\left[\mathrm{BPh}_{4}\right],\left[\mathrm{MeOC}_{2} \mathrm{mpip}\right] \mathrm{Cl}$ and $\left.\left[\mathrm{MeOC}_{2} \mathrm{mpyrr}\right] \mathrm{Br}\right)$ structures are listed in Table 3, according to the position of the 40 hydrogen atom in the cation; data for related pyrrolidinium and imidazolium salts, as retrieved from the CSD, are also given for comparison.

Table $3 \mathrm{CH} \cdots \mathrm{X}$ distances ${ }^{a}(\mathrm{X}=\mathrm{C}, \mathrm{Cl}$ or $\mathrm{Br})$ in the crystal structures of $\left[\mathrm{C}_{6} \mathrm{~mm}_{\beta}\right.$ pip $]\left[\mathrm{BPh}_{4}\right],\left[\mathrm{MeOC}_{2} \mathrm{mpyrr}\right] \mathrm{Br}$ and $\left[\mathrm{MeOC}_{2} \mathrm{mpip}\right] \mathrm{Cl}$; data for 45 related pyrrolidinium and imidazolium salts ${ }^{b}$ are also listed

\begin{tabular}{|c|c|c|c|}
\hline Anion & {$\left[\mathrm{BPh}_{4}\right]^{-}$} & $\mathrm{Cl}^{-}$ & $\mathrm{Br}^{-}$ \\
\hline \multirow{3}{*}{$\Sigma(\mathrm{VdW} \text { radii })^{a}$} & $d(\mathrm{CH} \cdots \mathrm{C}) / \AA$ & $d(\mathrm{CH} \cdots \mathrm{Cl}) / \AA$ & $d(\mathrm{CH} \cdots \mathrm{Br}) / \AA$ \\
\hline & 2.90 & 2.96 & 3.05 \\
\hline & {$\left[\mathrm{C}_{6} \mathrm{~mm}_{\beta}\right.$ pip $]\left[\mathrm{BPh}_{4}\right]$} & {$\left[\mathrm{MeOC}_{2} \mathrm{mpip}\right] \mathrm{Cl}$} & {$\left[\mathrm{MeOC}_{2} \mathrm{mpyrr}\right] \mathrm{Br}$} \\
\hline $\mathrm{C}_{\alpha} \mathrm{H}$ (ring) & 2.78 & $2.80(8)$ & $2.99(6)$ \\
\hline $\mathrm{NCH}$ (chain) & $2.80(9)$ & $2.82(8)$ & $2.92(8)$ \\
\hline $\mathrm{C}_{\beta} \mathrm{H}$ (ring) & $2.858(6)$ & $2.82(8)$ & 2.948 \\
\hline $\mathrm{C}_{\gamma} \mathrm{H}$ (ring) & 2.835 & & \\
\hline $\mathrm{OCH}_{3}$ & & $2.75(4)$ & \\
\hline \multirow[t]{3}{*}{ average } & $2.81(8)$ & $2.80(7)$ & $2.96(6)$ \\
\hline & & pyrrolidinium & \\
\hline & {$[\mathrm{Rmpyrr}]\left[\mathrm{BPh}_{4}\right]^{b, c}$} & {$\left[\mathrm{R}_{a} \mathrm{R}_{b}\right.$ pyrr $] \mathrm{Cl}^{b, d, e}$} & {$\left[\mathrm{R}_{a} \mathrm{R}_{b}\right.$ pyrr $] \mathrm{Br}^{b, e, f}$} \\
\hline $\mathrm{C}_{\alpha} \mathrm{H}$ (ring) & & $2.80(2)$ & $2.91(6)$ \\
\hline $\mathrm{NCH}$ (chain) & $2.79(9)$ & $2.78(5)$ & $2.95(9)$ \\
\hline $\mathrm{C}_{\beta} \mathrm{H}$ (ring) & & $2.78(2)$ & $2.98(3)$ \\
\hline $\mathrm{NCCH}$ (chain) & 2.883 & & \\
\hline \multirow[t]{3}{*}{ average } & $2.81(9)$ & $2.78(4)$ & $2.95(7)$ \\
\hline & & imidazolium & \\
\hline & {$\left[\mathrm{R}_{a} \mathrm{R}_{b} \mathrm{im}\right]\left[\mathrm{BPh}_{4}\right]^{b, e, g}$} & {$\left[\mathrm{R}_{a} \mathrm{R}_{b} \mathrm{im}\right] \mathrm{Cl}^{b, e, h}$} & {$\left[\mathrm{R}_{a} \mathrm{R}_{b} \mathrm{im}\right] \mathrm{Br}^{b, e, i}$} \\
\hline $\mathrm{C}^{2} \mathrm{H}$ & $2.78(7)$ & $2.53(6)$ & $2.70(12)$ \\
\hline $\mathrm{C}^{4,5} \mathrm{H}$ & $2.79(13)$ & $2.75(9)$ & $2.88(9)$ \\
\hline $\mathrm{C}_{\alpha} \mathrm{H}$ & $2.84(4)$ & $2.78(7)$ & $2.94(7)$ \\
\hline $\mathrm{C}_{\beta} \mathrm{H}$ & $2.81(7)$ & & $3.01(2)$ \\
\hline average & $2.80(9)$ & $2.73(12)$ & $2.88(12)$ \\
\hline
\end{tabular}

${ }^{a}$ Distances averaged for all contacts shorter than the sum of van der Waals (VdW) radii (refs. ${ }^{55,56}$ ). ${ }^{b}$ Data retrieved from the CSD are referred to by their six-letter codes. ${ }^{c}$ \#QEJGIX $\left(\right.$ ref. ${ }^{57}$ ). ${ }^{d}$ \#LIVWUJ, \#LIVWUJ01 (ref. ${ }^{58}$ ). ${ }^{e} \mathrm{R}_{a}$ and $\mathrm{R}_{b}$ denote any $\mathrm{N}$-substituents bonded through a non50 metal atom. ${ }^{f}$ \#KUKSOZ, \#YUHFUD, \#YUHGAK (ref. ${ }^{59}$ ). ${ }^{g}$ \#DOJNUM, \#TUXMIJ, \#WITJUE, \#WITJUE01, \#WUNSON, \#WUNTAA $\left(\right.$ ref. $\left.{ }^{60}\right) .{ }^{h}$ \#JUFBUH, \#TAJCUD, \#TAJCUD02, \#TAJCUD03, \#VEPFOL01, \#VEPFOL02 (ref. ${ }^{61,62}$ ). ${ }^{i}$ \#EBUDOV, \#EBUDUB, \#JIRBUI, \#JIRCAP, \#JIRCAP01, \#TAJDAK, \#TAJDAK01, 55 \#TAJDAK02, \#ZIBHUN, \#ZIBHUN01, \#ZIBHUN02 (refs. ${ }^{59,62,63}$ ).

The case of the tertiary ammonium salt $\left[\mathrm{C}_{4} \mathrm{Hm}_{\beta} \mathrm{pip}\right] \mathrm{Br}$, due to the presence of the distinguishably acidic NH proton, is remarkably different to those of the other reported (quaternary ammonium) structures. In this crystal structure, cations and bromide anions 60 are hydrogen-bonded into infinite ribbons which run parallel to the crystallographic $c$-axis (Fig. 8). The interactions responsible for the formation of such ribbons are hydrogen bonds established between each bromide anion and, on one side, one nitrogenbonded hydrogen atom and, at the other end, one hydrogen atom ${ }_{65}$ bonded to $\mathrm{C}^{2}$ in the next 3-methylpiperidinium ring. The $\mathrm{N}-\mathrm{H} \cdots \mathrm{Br}$ and $\mathrm{C}-\mathrm{H} \cdots \mathrm{Br}$ distances are 2.306 and $2.916 \AA$, respectively, thus indicating that the former (contact $c a$. $0.75 \AA$ shorter than the sum of van der Waals radii) is the strongest of the two, as expected from the higher acidity of the NH moiety.

70 In the crystalline lattice of $\left[\mathrm{C}_{6} \mathrm{~mm}_{\beta}\right.$ pip $]\left[\mathrm{BPh}_{4}\right]$, each cation is surrounded by four anions (and vice versa) in a pseudo-square coordination, thus forming planes which run parallel to the crystallographic ac plane. The closest contacts are established between hydrogen atoms in the cations and a number of phenyl 75 carbon atoms in the anions. The mean $\mathrm{H} \cdots \mathrm{C}$ distance is 2.81(8) $\AA$, marginally shorter than the sum of van der Waals radii $(2.90 \AA$, see Table 3). This indicates the presence of weak hydrogen 
bonding between relatively acidic hydrogen atoms in the cations (mostly those in either the $\alpha$ or $\beta$ positions from the nitrogen atoms) and the $\pi$-system of the phenyl rings in the anions. Similar $\mathrm{H} \cdots \mathrm{C}$ distances are observed in the complex dicobalt 5 1-methyl-1-(prop-2-yn-1-yl)pyrrolidinium $(2.81(9) \AA)^{57}$ and in several imidazolium salts (2.80(9) $\AA$, see Table 3$).^{60}$
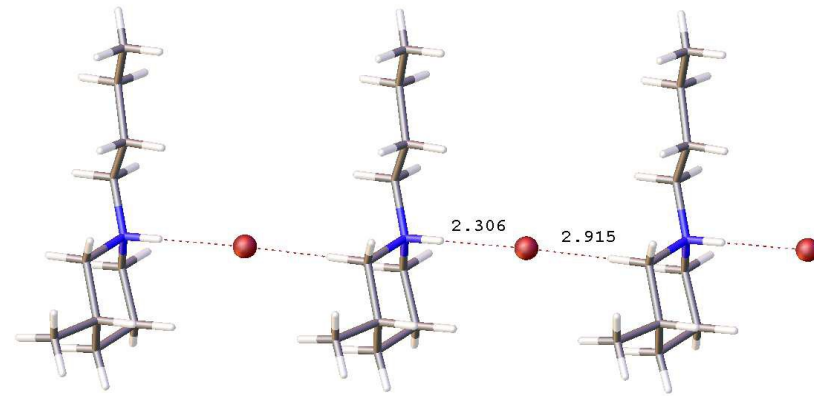

Fig. 8 A perspective of cation-anion coordination into ribbons parallel to the $c$ axis in the crystal structure of $\left[\mathrm{C}_{4} \mathrm{Hm}_{\beta}\right.$ pip]Br. Dotted red lines indicate $\mathrm{H} \cdots$ anion contacts; distances $(\AA)$ are given in black.

White $=$ hydrogen; grey $=$ carbon; blue $=$ nitrogen; crimson $=$ bromine .

Anion coordination around $\left[\mathrm{MeOC}_{2} \mathrm{mpip}\right] \mathrm{Cl}$ and $\left[\mathrm{MeOC}_{2}\right.$ mpyrr $] \mathrm{Br}$ cations is shown in Fig. 7. As mentioned above, the 2-methoxyethyl side chains bend towards the ring, 15 most likely stabilised by intramolecular $\mathrm{CH} \cdots \mathrm{O}$ contacts (vide supra). Moreover, several interionic $\mathrm{CH} \cdots \mathrm{X}(\mathrm{X}=\mathrm{Cl}, \mathrm{Br})$ contacts are observed for both structures. In the case of $\left[\mathrm{MeOC}_{2} \mathrm{mpip}\right] \mathrm{Cl}$, each cation is surrounded by five chloride anions, Fig. 7(a). The average $\mathrm{CH} \cdots \mathrm{Cl}$ distance is $2.80(7) \AA$, which is slightly shorter 20 than the sum of van der Waals radii (see Table 3) and indistinguishable from those found in known pyrrolidinium chloride structures. ${ }^{58}$ On the other hand, four bromide anions are observed to coordinate each cation in $\left[\mathrm{MeOC}_{2} \mathrm{mpyrr}\right] \mathrm{Br}$, Fig. 7(b). The mean $\mathrm{CH}^{\cdots} \cdot \mathrm{Br}$ distance is 2.96(6) $\AA$, marginally

25 shorter than the sum of van der Waals radii and, as in the case of chlorides discussed above, and in the range of those for related pyrrolidinium bromides. ${ }^{59}$ Imidazolium chlorides ${ }^{61,}{ }^{62}$ and bromides $^{59}, 62,63$ show average contacts of 2.73(12) and 2.88(12) $\AA$, respectively, although these figures are heavily 30 weighted by very short contacts to the acidic $\mathrm{C}^{2} \mathrm{H}$ ring proton: the rest of the contacts are close to the distances for the piperidinium and pyrrolidinium systems already discussed (see Table 3). Therefore, imidazolium halides show distinguishably stronger hydrogen bonds to $\mathrm{C}^{2} \mathrm{H}$, whereas in the structures of related 35 piperidinium and pyrrolidinium analogues, a number of weak interionic hydrogen bonds dominate the structures.

\section{Thermal behaviour}

Depending on the substituents on the nitrogen atom and on the counteranion, the 3-methylpiperidinium salts reported herein are 40 either solids of low melting point or liquids at ambient conditions. Their glass transition temperatures and melting points, as measured by DSC, are listed in Table 4. All substances based on the $\left[\mathrm{NTf}_{2}\right]^{-}$anion are room temperature ionic liquids, only showing glass transition temperatures below $-69^{\circ} \mathrm{C}$. In

45 contrast, the phase behaviour of iodide, trifluoroethanoate and trifluoromethanesulfonate salts strongly depends on the $\mathrm{N}$-substituents; those having alkyl substituted cation cores are crystalline solids at room temperature, whereas analogues containing ether-linked side chains are (in most cases) room 50 temperature ionic liquids which do not crystallise upon cooling, but rather form glasses. For example, $\left[\mathrm{C}_{4} \mathrm{~mm}_{\beta}\right.$ pip][OTf] is a solid which melts at $84{ }^{\circ} \mathrm{C}$, whereas $\left[\mathrm{MeOC}_{2} \mathrm{~mm}_{\beta}\right.$ pip][OTf] is a liquid which does not crystallise, but turns into a glass instead $\left(T_{\mathrm{g}}=-60^{\circ} \mathrm{C}\right)$, upon cooling. Therefore, the replacement of a ${ }_{55}$ methylene unit with an oxygen atom in the $\mathrm{R}$ group causes a drastic enhancement $\left(144^{\circ} \mathrm{C}\right)$ of the liquid range.

Table 4 Phase transition ${ }^{a, b, c}$ and decomposition ${ }^{d}$ data of 3-methylpiperidinium and related piperidinium and pyrrolidinium salts

\begin{tabular}{|c|c|c|c|c|}
\hline [Q] & $T_{\mathrm{g}}(\Delta H)^{a, b}$ & $T_{\mathrm{c}}(\Delta H)^{b, c}$ & $T_{\mathrm{m}}(\Delta H)^{a, b}$ & $T_{\mathrm{dec}}{ }^{d}$ \\
\hline & \multicolumn{4}{|c|}{$\mathrm{X}=\left[\mathrm{NTf}_{2}\right]$} \\
\hline$\left[\mathrm{C}_{4} \mathrm{~mm}_{\beta}\right.$ pip $]$ & -69 & & & 340 \\
\hline$\left[\mathrm{C}_{6} \mathrm{~mm}_{\beta}\right.$ pip $]$ & -70 & & & 360 \\
\hline$\left[\mathrm{MeOC}_{2} \mathrm{~mm}_{\beta} \mathrm{pip}\right]$ & -70 & & & 340 \\
\hline$\left[\mathrm{MeOC}_{2} \mathrm{OC}_{2} \mathrm{~mm}_{3} \mathrm{pip}\right]$ & -77 & & & 330 \\
\hline$\left[\mathrm{MeOC}_{2} \mathrm{mpip}\right]$ & $-82^{e} /-80^{f}$ & & & $417^{e}$ \\
\hline$\left[\mathrm{MeOC}_{2} \mathrm{mpyrr}\right]$ & $-91 /-91^{e} /-88^{f}$ & & & $416^{e}$ \\
\hline \multirow[t]{2}{*}[\mathrm{MeOC}_{2}\mathrm{OC}_{2}\mathrm{mpyrr}]{} & -89 & & & 330 \\
\hline & \multicolumn{4}{|c|}{$\mathrm{X}=[\mathrm{OTf}]$} \\
\hline$\left[\mathrm{C}_{4} \mathrm{~mm}_{\beta} \mathrm{pip}\right]$ & & & 84 & \\
\hline$\left[\mathrm{C}_{6} \mathrm{~mm}_{\beta} \mathrm{pip}\right]$ & & $71(16.8)$ & $82(18.3)$ & 320 \\
\hline$\left[\mathrm{MeOC}_{2} \mathrm{~mm}_{\beta} \mathrm{pip}\right]$ & $-60(0.5)$ & & & 330 \\
\hline \multirow{2}{*}[\mathrm{MeOC}_{2}\mathrm{OC}_{2}\mathrm{mm}_{\beta}\mathrm{pip}]{} & -68 & & & 310 \\
\hline & \multicolumn{4}{|c|}{$\mathrm{X}=\left[\mathrm{CF}_{3} \mathrm{CO}_{2}\right]$} \\
\hline$\left[\mathrm{C}_{4} \mathrm{~mm}_{\beta}\right.$ pip $]$ & & & 58 & \\
\hline$\left[\mathrm{C}_{6} \mathrm{~mm}_{\mathrm{B}} \mathrm{pip}\right]$ & & $37(9.8)$ & $41(8.0)$ & 180 \\
\hline$\left[\mathrm{MeOC}_{2} \mathrm{~mm}_{\beta} \mathrm{pip}\right]$ & $-61(0.6)$ & & & 150 \\
\hline \multirow[t]{2}{*}[\mathrm{MeOC}_{2}\mathrm{OC}_{2}\mathrm{mm}_{\beta}\text{pip}]{} & $-73(0.4)$ & & & 150 \\
\hline & \multicolumn{4}{|c|}{$\mathrm{X}=\mathrm{I}$} \\
\hline$\left[\mathrm{C}_{4} \mathrm{~mm}_{\beta}\right.$ pip $]$ & & & $144(4.2)$ & 180 \\
\hline$\left[\mathrm{C}_{6} \mathrm{~mm}_{\mathrm{p}} \mathrm{pip}\right]$ & & & 123 & 180 \\
\hline$\left[\mathrm{MeOC}_{2} \mathrm{OC}_{2} \mathrm{~mm}_{\beta} \mathrm{pip}\right]$ & -46 & & & 180 \\
\hline
\end{tabular}

${ }^{a}$ Glass transition $\left(T_{\mathrm{g}}\right)$ and melting $\left(T_{\mathrm{m}}\right)$ temperatures $\left(\right.$ in $\left.{ }^{\circ} \mathrm{C}\right)$ are listed as 60 measured from the heating cycles in DSC traces. ${ }^{b}$ Enthalpy changes, where measurable, are given in brackets (in $\mathrm{kJ} \mathrm{mol}^{-1}$ ). ${ }^{c}$ Crystallisation temperatures $\left(T_{\mathrm{c}}\right)$ are listed as measured from the cooling cycles in DSC traces. ${ }^{d}$ Decomposition temperatures $\left(T_{\mathrm{dec}}\right.$, in $\left.{ }^{\circ} \mathrm{C}\right)$ were determined from the onset of weight loss in dynamic TGA traces under a dinitrogen 65 atmosphere. ${ }^{e}$ From reference ${ }^{30} .{ }^{f}$ From reference ${ }^{64}$.

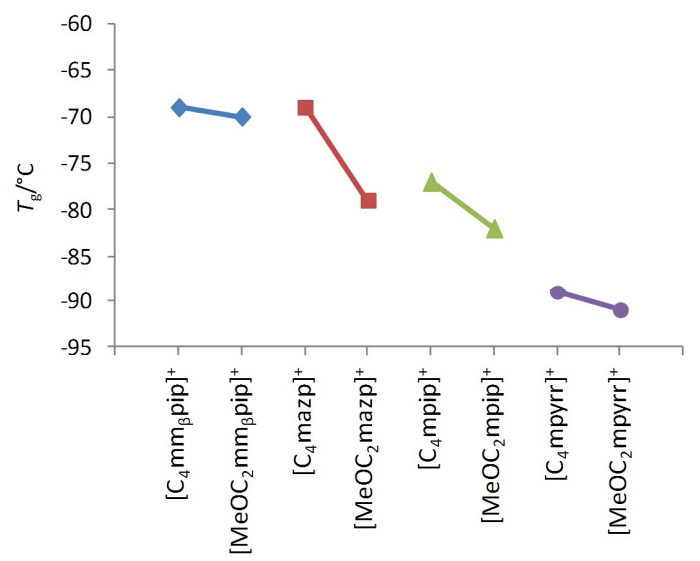

Fig. 9 Glass transition temperatures $\left(T_{\mathrm{g}}\right)$ for ionic liquids with $\left[\mathrm{NTf}_{2}\right]$ anion derived from 3-methylpiperidine (diamonds), azepane (squares), piperidine (triangles) and pyrrolidine (circles). For some salts, data from $70 \quad$ literature (reference ${ }^{30}$ ) are plotted for comparison.

Table 4 includes phase transitions for 1-R-1-methylpiperidinium salts ([Rmpip]X, i.e. non-carbon- 
substituted analogues of $\left.\left[\mathrm{Rmm}_{\beta} \mathrm{pip}\right] \mathrm{X}\right)$ and for their pyrrolidinium counterparts. The thermal behaviour of bistriflamide salts is similar for all the listed salts, all having glass transition temperatures ranging between -91 and $-69^{\circ} \mathrm{C}$. A 5 decreasing trend in such transition temperatures is observed as the number of atoms in the cationic ring core (including the methyl substituent in $\left[\mathrm{Rmm}_{\beta} \mathrm{pip}\right]^{+}$salts) decreases, as seen in Fig. 9 for four-atom side chains. Moreover, the replacement of butyl with ether-linked 2-methoxyethyl causes a slight decrease 10 in glass transition temperatures in all cases.

More importantly, while $\left[\mathrm{C}_{4}\right.$ mpip $]\left[\mathrm{NTf}_{2}\right]^{65}$ and $\left[\mathrm{C}_{4} \mathrm{mpyrr}\right]\left[\mathrm{NTf}_{2}\right]^{17}, 30, \quad 66$ show crystallisation (and the corresponding melting) events at low temperatures, none of the 3-methylpiperdinium ionic liquids studied here exhibit this 15 phenomenon. It should be noted that a certain degree of discrepancy in data from the literature, most likely due to different thermal history in the DSC measurements, has been found. In the case of $\left[\mathrm{C}_{4} \mathrm{mpip}\right]\left[\mathrm{NTf}_{2}\right]$, a sample cycled at a $10{ }^{\circ} \mathrm{C} \mathrm{min}{ }^{-1}$ rate only showed a glass transition $\left(-77^{\circ} \mathrm{C}\right),{ }^{30}$ 20 whereas both glass transition and melting events have been reported $\left(-73{ }^{\circ} \mathrm{C}\right.$ and $-25^{\circ} \mathrm{C}$, respectively) recording at a $20{ }^{\circ} \mathrm{C} \mathrm{min}{ }^{-1}$ heating rate after $1 \mathrm{~h}$ annealing at $-80{ }^{\circ} \mathrm{C} .{ }^{65} \mathrm{In}$ contrast, only a glass transition at $-69{ }^{\circ} \mathrm{C}$ has been observed here for $\left[\mathrm{C}_{4} \mathrm{~mm}_{\beta}\right.$ pip $]\left[\mathrm{NTf}_{2}\right]$ on DSC measurements performed at ${ }_{25} 5^{\circ} \mathrm{C} \mathrm{min}{ }^{-1}$ scan rate between -100 and $100{ }^{\circ} \mathrm{C}$. Similarly, no crystallisations have been observed for any $\left[\mathrm{Rmm}_{\beta} \mathrm{pip}\right] \mathrm{X}$ $\left(\mathrm{X}=[\mathrm{OTf}]\right.$ or $\left.\left[\mathrm{CF}_{3} \mathrm{CO}_{2}\right]\right)$ ionic liquids containing ether linkages on the $\mathrm{R}$ group, as opposed to their [Rmazp]X isomers, which have a tendency to crystallise and then melt while heating at 30 temperatures around or below ambient. ${ }^{38}$ Therefore, the introduction of a methyl substitution on the ring and/or the fact that a mixture of diastereoisomers occur in $\left[\mathrm{Rmm}_{\beta} \mathrm{pip}\right] \mathrm{X}$ may frustrate crystallisation in this type of salts, thus enabling wider liquid ranges, i.e. lowering low liquid limits. Even one of the 35 iodide salts herein presented, $\left[\mathrm{MeOC}_{2} \mathrm{OC}_{2} \mathrm{~mm}_{\beta} \mathrm{pip}\right] \mathrm{I}$, is a room temperature ionic liquid $\left(T_{\mathrm{g}}=-46^{\circ} \mathrm{C}\right.$, see Table 4$)$.

Decomposition temperatures of $\left[\mathrm{Rmm}_{\beta} \mathrm{pip}\right]^{+}$salts were estimated as the onset of weight loss from TGA profiles (see Table 4); literature data for some salts, also included, should be 40 compared with care since the heating rates were different. Higher figures $\left(400-430{ }^{\circ} \mathrm{C}\right)$ are apparent for previously reported [Rmpyrr] $\left[\mathrm{NTf}_{2}\right]$ or $[\mathrm{Rmpip}]\left[\mathrm{NTf}_{2}\right]$ than have been measured for analogous [Rmazp][NTf $\left.\mathrm{NT}_{2}\right]$ or $\left[\mathrm{Rmm}_{\beta} \mathrm{pip}\right]\left[\mathrm{NTf}_{2}\right]$ salts $(330-$ $360^{\circ} \mathrm{C}$ ), but this might be due to faster scanning rates for the 45 former $\left(10\right.$ or $\left.20^{\circ} \mathrm{C} \mathrm{min}^{-1}\right),{ }^{30,65}$ as compared to this (and its related $)^{38}$ report $\left(5^{\circ} \mathrm{C} \mathrm{min}^{-1}\right)$. This fact also reflects that dynamic thermogravimetric measurements are at best semiquantitative in nature, and decomposition temperatures derived thereof vary as a function of the heating rate and sample size; ${ }^{67}$ furthermore, they 50 are significantly higher than those measured from static (longterm) analyses. ${ }^{11}$ However, the data presented here clearly show that thermal stability clearly decreases following the (expected) $\left[\mathrm{NTf}_{2}\right]^{-}>[\mathrm{OTf}]^{-}>>\mathrm{I}^{-}>\left[\mathrm{CF}_{3} \mathrm{CO}_{2}\right]^{-}$anionic order.

\section{Density}

${ }_{55}$ Experimental density data for $\left[\mathrm{Rmm}_{\beta} \mathrm{pip}\right]^{+},[\mathrm{Rmpip}]^{+}$and $[\mathrm{Rmpyrr}]^{+}$room temperature ionic liquids have been determined between 20 and $90{ }^{\circ} \mathrm{C}$ (see ESI). All density data sets fit linear trendlines within this temperature range, as seen in the plots shown in Fig. 10. In general, density increases in the ${ }_{60}\left[\mathrm{CF}_{3} \mathrm{CO}_{2}\right]^{-}<[\mathrm{OTf}]^{-}<\left[\mathrm{NTf}_{2}\right]^{-}$anionic order. A further increase is observed as a function of the $\mathrm{R}$ substituent in the cation core in the order $\mathrm{C}_{6}<\mathrm{C}_{4}<\mathrm{MeOC}_{2} \mathrm{OC}_{2}<\mathrm{MeOC}_{2}$. These results confirm the patterns previously reported for their azepanium analogues. ${ }^{38}$ Furthermore, data for [Rmpip] $\left[\mathrm{NTf}_{2}\right]$ and $\left.\left[\mathrm{Rmpyrr}_{[}\right] \mathrm{NTf}_{2}\right]$ are in ${ }_{65}$ good agreement with literature reports. ${ }^{14,30,64}$

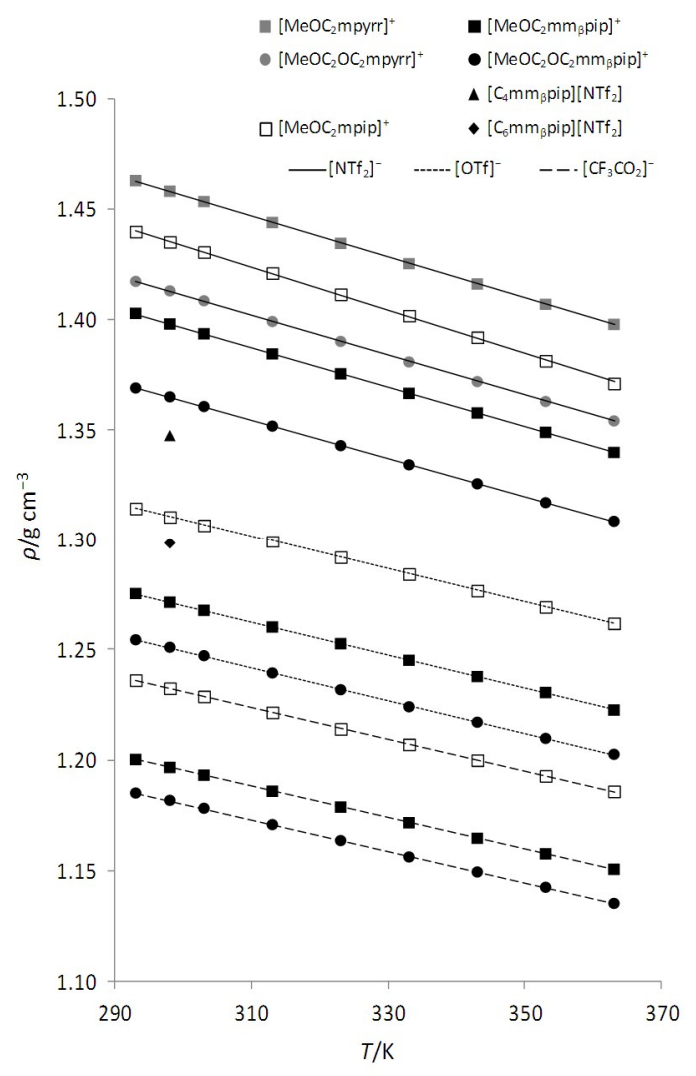

Fig. 10 Experimental density of the studied ionic liquids as a function of the temperature. Fitted trendlines are shown for each data set; solid, dotted and dashed lines fit $\left[\mathrm{NTf}_{2}\right]^{-},[\mathrm{OTf}]^{-}$and $\left[\mathrm{CF}_{3} \mathrm{CO}_{2}\right]^{-}$ionic liquid 70 densities, respectively.

Data in this work expand the range of ionic liquids based on $\mathrm{N}$-alicyclic cations with thoroughly studied physical properties, thus allowing a systematic comparison to be made. Densities at $25^{\circ} \mathrm{C}$ of different liquid salts with 3-methylpiperidinium, 75 azepanium, piperidinium or pyrrolidinium cations having methyl and 2-methoxyethyl as N-substituents is comparatively shown in Fig. 11 . The same pattern previously observed for $\left[\mathrm{NTf}_{2}\right]^{-}$ionic liquids ${ }^{25}$ is followed by their $\left[\mathrm{CF}_{3} \mathrm{CO}_{2}\right]^{-}$and $[\mathrm{OTf}]^{-}$counterparts.

Density consistently decreases exhibiting two distinctive 80 behaviours. In pattern $(a)$, this is induced by the introduction of asymmetry into the ring, i.e. the 3-methyl group on piperidinium, where as in pattern $(b)$, it is induced by increasing the ring size. In this context, $\left[\mathrm{MeOC}_{2}\right.$ mpip] $\left[\mathrm{CF}_{3} \mathrm{CO}_{2}\right]$ exhibits a higher density at $25{ }^{\circ} \mathrm{C}\left(1.2324 \mathrm{~g} \mathrm{~cm}^{-3}\right)$ than both its 3-methyl substituted 85 analogue $\left[\mathrm{MeOC}_{2} \mathrm{~mm}_{\beta}\right.$ pip $]\left[\mathrm{CF}_{3} \mathrm{CO}_{2}\right]\left(1.1966 \mathrm{~g} \mathrm{~cm}^{-3}\right.$, pattern $\left.(a)\right)$ and its 7-member ring counterpart $\left[\mathrm{MeOC}_{2}\right.$ mazp $]\left[\mathrm{CF}_{3} \mathrm{CO}_{2}\right]$ $\left(1.2179 \mathrm{~g} \mathrm{~cm}^{-3}\right.$, pattern $\left.(b)\right) .{ }^{38}$ It should also be noted that, as seen for examples in the last two figures, lower densities are observed for 3-methylpiperidinium ionic liquids as compared to their 90 azepanium isomers, although having identical molecular weights. 


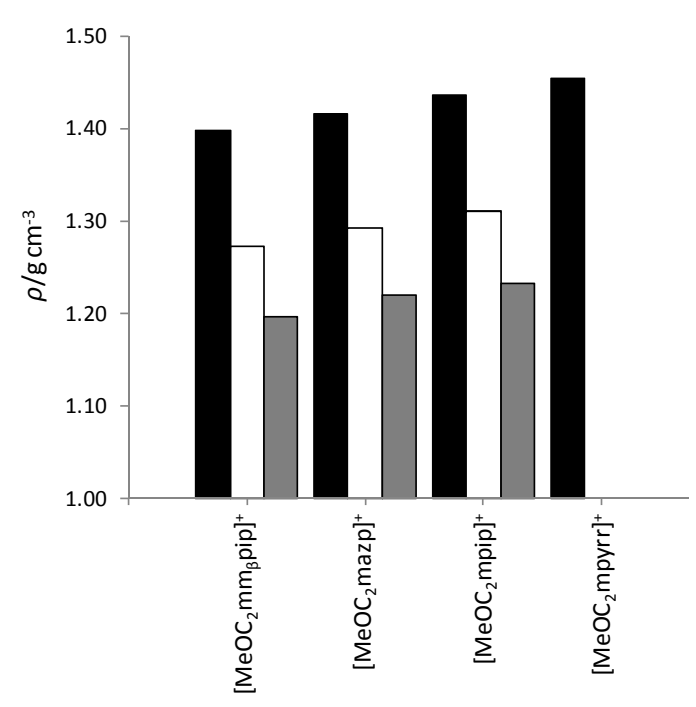

Fig. 11 Densitites $\left(25^{\circ} \mathrm{C}\right)$ for $\left.\mathrm{NTf}_{2}\right]^{-}$(black bars), [OTf] $]^{-}$(white bars) and $\left[\mathrm{CF}_{3} \mathrm{CO}_{2}\right]^{-}$(grey bars) ionic liquids having 2-methoxyethyl as side chain on different cation cores. Data from the literature are included for $[\text { Rmazp }]^{+}$ionic liquids $\left(\right.$ref. ${ }^{38}$ ).

This is similarly true for the cycloalkanes, methylcyclohexane and cycloheptane $\left(0.7694\right.$ and $0.8098 \mathrm{~g} \mathrm{~cm}^{-3}$ at $20^{\circ} \mathrm{C}$, respectively). ${ }^{68}$

In summary, the density of ionic liquids based on alkylated 10 cyclic ammonium cations can be finely tuned by the choice of counteranion $\left(\left[\mathrm{CF}_{3} \mathrm{CO}_{2}\right]^{-}<[\mathrm{OTf}]^{-}<\left[\mathrm{NTf}_{2}\right]^{-}\right)$, ring size (lighter for larger rings), the type of N-substituents (heavier for etherlinked as compared to plain alkyl) and ring asymmetry (3methylpiperidinium ionic liquids being lighter than non15 substituted piperidinium analogues).

\section{Viscosity}

Viscosity measurements for the room temperature ionic liquids studied were performed between 25 and $95{ }^{\circ} \mathrm{C}$ (a complete set of is listed in the ESI). The temperature dependence of the 20 viscosity for all the studied ionic liquids is graphically depicted in Fig. 12. The most influential factor affecting viscosity was found to be the anion. For a given cation, viscosity clearly decreases in the $[\mathrm{OTf}]^{-}>\left[\mathrm{CF}_{3} \mathrm{CO}_{2}\right]^{-}>\left[\mathrm{NTf}_{2}\right]^{-}$anionic order, as is the case for the $\left[\mathrm{MeOC}_{2} \mathrm{mpip}\right] \mathrm{X}$ series, where values 25 of $401.1,288.1$ and $103.4 \mathrm{cP}$ were measured at $25^{\circ} \mathrm{C}$, following the aforesaid anion sequence. Moreover, good agreement is found between data reported here and elsewhere for both $\left[\mathrm{MeOC}_{2}\right.$ mpip $]\left[\mathrm{NTf}_{2}\right]^{30,64}$ and $\left[\mathrm{MeOC}_{2}\right.$ mpyrr $]\left[\mathrm{NTf}_{2}\right] .{ }^{30,64,69}$

In the case of $\left[\mathrm{Rmm}_{\beta} \mathrm{pip}\right]\left[\mathrm{NTf}_{2}\right]$, viscosities decrease as a 30 function of the $\mathrm{R}$ group in the following order: $\mathrm{C}_{6}>\mathrm{C}_{4}>\mathrm{MeOC}_{2}>\mathrm{MeOC}_{2} \mathrm{OC}_{2}$. Thus, $\left[\mathrm{C}_{4} \mathrm{~mm}_{\beta}\right.$ pip $]\left[\mathrm{NTf}_{2}\right]$ has a considerably lower viscosity at $25^{\circ} \mathrm{C}$ than its hexyl analogue, $\left[\mathrm{C}_{6} \mathrm{~mm}_{\beta}\right.$ pip] $\left[\mathrm{NTf}_{2}\right]$, (315.3 and $391.7 \mathrm{cP}$, respectively). Even more dramatic density reductions are observed when ether 35 linkages are introduced in the $\mathrm{R}$ side chain, as reported elsewhere for a range of ionic liquids. ${ }^{38,70}$ Viscosity drops by almost $60 \%$ by replacing butyl with a 2-methoxyethyl chain $(135.5 \mathrm{cP}$ at $25^{\circ} \mathrm{C}$ for $\left[\mathrm{MeOC}_{2} \mathrm{~mm}_{\beta}\right.$ pip] $\left.\left[\mathrm{NTf}_{2}\right]\right)$, which is a striking reduction if one considers that the only structural difference is an oxygen 40 instead of a methylene unit in the R substituent. Elongation of the ether-linked chains enhances the fluidity of the ionic liquids for any given anion or cationic core. For example, the viscosities of $\left[\mathrm{Rmm}{ }_{\beta}\right.$ pip][OTf] at $25^{\circ} \mathrm{C}$ are 654.3 and $408.9 \mathrm{cP}$ (ca. $40 \%$ reduction) for $\mathrm{R}=\mathrm{MeOC}_{2}$ and $\mathrm{MeOC}_{2} \mathrm{OC}_{2}$, respectively.

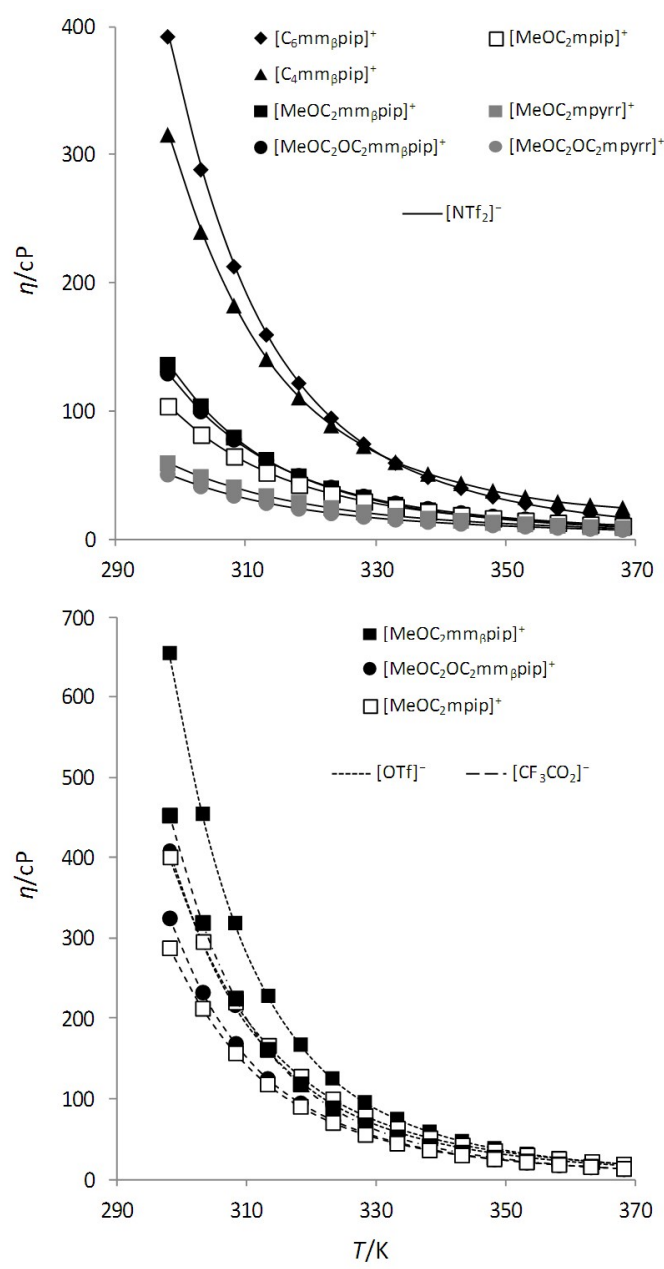

Fig. 12 Experimental viscosity data for the studied ionic liquids as a function of the temperature. Fitted VFT lines are shown for each data set; solid, dotted and dashed lines fit $\left[\mathrm{NTf}_{2}\right]^{-}$, [OTf] $]^{-}$and $\left[\mathrm{CF}_{3} \mathrm{CO}_{2}\right]^{-}$ionic liquid viscosities, respectively.

50 These patterns have been observed for related azepanium ionic liquids. ${ }^{38}$ Furthermore, new viscosity data presented in this article allow for a more complete comparative study amongst different cationic cores, i.e. 7-, 6- and 5- member rings (azepanium, piperidinium and pyrrolidinium), in addition to asymmetric 355 methylpiperidinium, and different anions, to be performed. Such a comparison is shown in Fig. 13 for ionic liquids having 2methoxyethyl as the $\mathrm{R}$ side chain. In addition to the anion effect (see above), the viscosity is clearly affected by the structure of the cationic core, showing a decreasing trend in the following 60 order: azepanium $>3$-methylpiperidinium $>$ piperidinium $>$ pyrrolidinium. This was previously reported for $\left[\mathrm{NTf}_{2}\right]^{-}$salts, ${ }^{25}$ whereas new data show that the viscosity reduction is much greater for either $[\mathrm{OTf}]^{-}$or $\left[\mathrm{CF}_{3} \mathrm{CO}_{2}\right]^{-}$salts, at least for 7- and 6member ring systems. Generally, viscosity decreases with $(a)$ 65 decreasing ring size, for (symmetric) non- $C$-substituted structures, and (b) introduction of asymmetry for cations of identical weight (3-methylpiperidinium $v s$. azepanium isomers). 
These patterns are clearly demonstrated in the following examples: [ $\mathrm{MeOC}_{2}$ mazp][OTf] exhibits a noticeably higher viscosity at $25^{\circ} \mathrm{C}(797.5 \mathrm{cP})$ than either its piperidinium analogue $\left[\mathrm{MeOC}_{2} \mathrm{mpip}\right][\mathrm{OTf}](401.1 \mathrm{cP}$, pattern $(a))$, or its 5 asymmetric isomer $\left[\mathrm{MeOC}_{2} \mathrm{~mm}_{\beta} \mathrm{pip}\right][\mathrm{OTf}](654.3 \mathrm{cP}$, pattern (b)).

A decrease in viscosity with increasing temperature is observed (see Fig. 12). Such a decrease is more dramatic for ionic liquids of higher viscosity. As usual for other ionic 10 liquids, ${ }^{71}$ a viscosity-temperature correlation based on the Vogel-Fülcher-Tammann ${ }^{72}\left(\mathrm{VFT} ; \ln (\eta)=\ln \left(\eta_{0}\right)+\mathrm{B} /\left(T-T_{0}\right)\right)$ equation is proposed, where $\eta$ is the experimental viscosity in $\mathrm{cP}, T$ is given in Kelvin, and $\eta_{\mathrm{o}}, B$ and $T_{\mathrm{o}}$ represent the correlation parameters. The reduction in viscosity with 15 increasing temperature is dramatic, as can be seen in Fig. 12; for example, all azepanium ionic liquids show viscosities around or below $30 \mathrm{cP}$ at $90{ }^{\circ} \mathrm{C}$.

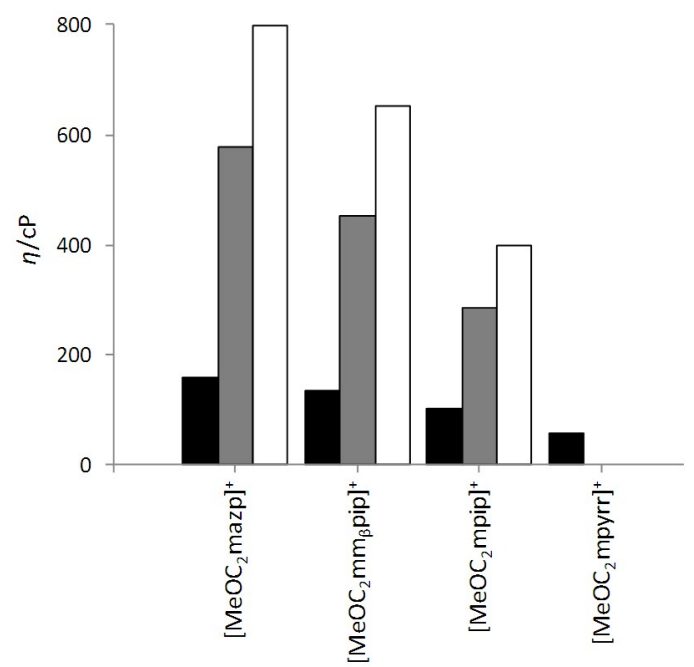

Fig. 13 Viscosities $\left(25^{\circ} \mathrm{C}\right.$ ) for $\left[\mathrm{NTf}_{2}\right]^{-}$(black bars), $\left[\mathrm{CF}_{3} \mathrm{CO}_{2}\right]^{-}$(grey 20 bars) and [OTf] $]^{-}$(white bars) ionic liquids having 2-methoxyethyl as side chain on different cationic cores. Data from the literature are included for $[\text { Rmazp }]^{+}$ionic liquids $\left(\right.$ref. ${ }^{38}$ ).

\section{Conductivity}

The ionic conductivities (both absolute and molar) of the 25 studied 3-methylpiperidinium, piperidinium and pyrrolidinium ionic liquids at $25^{\circ} \mathrm{C}$ are listed in Table 5. In addition, a Walden plot containing such data, along with those of some previously reported, closely related ionic liquids, is shown in Fig. 14.

For ionic liquids having identical cations, conductivities 30 increase in the $[\mathrm{OTf}]^{-}<\left[\mathrm{CF}_{3} \mathrm{CO}_{2}\right]^{-}<<\left[\mathrm{NTf}_{2}\right]^{-}$anionic order, which parallels the fluidity trend discussed above. In the case of $\left[\mathrm{NTf}_{2}\right]^{-}$ionic liquids, it has been previously shown that the introduction of ether-linkages on the $\mathrm{N}$-side chains (R) of alicyclic cations causes a drastic increase in conductivity. ${ }^{25}, 69,70$, ${ }_{35}{ }^{73}$ This is most likely a consequence of increased ionic mobility in the liquid state enabled by the higher flexibility and conformational freedom of chains having ether functionalities, rather than entirely alkyl character. In contrast, azepanium ionic liquids with 2-(2-methoxyethoxy)ethyl chain, despite their lower 40 viscosities, exhibit lower conductivities than their analogues with the shorter 2-methoxyethyl. ${ }^{38}$ Such a trend is confirmed here for
$\left[\mathrm{Rmm}_{\beta}\right.$ pip $]\left[\mathrm{NTf}_{2}\right]$ and, even to a greater extent, for [Rmpyrr] $\left.\mathrm{NTf}_{2}\right]$ (see Table 5). Thus, although the viscosity of $\left[\mathrm{MeOC}_{2} \mathrm{OC}_{2} \mathrm{mpyrr}\right]\left[\mathrm{NTf}_{2}\right]$ is lower than that of $45\left[\mathrm{MeOC}_{2} \mathrm{mpyrr}_{[}\left[\mathrm{NTf}_{2}\right] \quad\left(49.8\right.\right.$ vs. $58.6 \mathrm{cP}$ at $\left.25^{\circ} \mathrm{C}\right)$, the conductivity is noticeably lower for the former (2.22 vs. $3.30 \mathrm{~ms} \mathrm{~cm}^{-1}$ at the same temperature). This anomalous phenomenon may be ascribed to a higher degree of ionic association into either ionic pairs or aggregates, which can be 50 graphically observed in the form of a Walden plot (Fig. 14), whereby larger deviations below the $\mathrm{KCl}$ line (ideal ionic behaviour) mean lower ionicity, ${ }^{74}$ i.e. a higher tendency for cations and anions to aggregate in the pure ionic liquid state.

Table 5 Experimental conductivity $(\sigma)^{a}$ and molar conductivity $(\Lambda)$ data 55 for the studied 3-methylpiperidinium-, piperidinium- and pyrrolidiniumbased room temperature ionic liquids $[\mathrm{Q}] \mathrm{X}$.

\begin{tabular}{|c|c|c|}
\hline [Q] & $\sigma / \mathrm{mS} \mathrm{cm}^{-1}$ & $\Lambda / \mathrm{S} \mathrm{cm}^{2} \mathrm{~mol}^{-1}$ \\
\hline & \multicolumn{2}{|c|}{$\mathrm{X}=\left[\mathrm{NTf}_{2}\right]$} \\
\hline$\left[\mathrm{C}_{4} \mathrm{~mm}_{\beta}\right.$ pip $]$ & 0.55 & 0.183 \\
\hline$\left[\mathrm{C}_{6} \mathrm{~mm}_{\beta} \mathrm{pip}\right]$ & 0.32 & 0.117 \\
\hline$\left[\mathrm{MeOC}_{2} \mathrm{~mm}_{\beta} \mathrm{pip}\right]$ & 1.19 & 0.386 \\
\hline$\left[\mathrm{MeOC}_{2} \mathrm{OC}_{2} \mathrm{~mm}_{\beta} \mathrm{pip}\right]$ & 1.10 & 0.369 \\
\hline$\left[\mathrm{MeOC}_{2} \mathrm{mpyrr}\right]$ & 3.30 & 0.963 \\
\hline \multirow[t]{2}{*}[\mathrm{MeOC}_{2}\mathrm{OC}_{2}\mathrm{mpyrr}]{} & 2.22 & 0.737 \\
\hline & \multicolumn{2}{|c|}{$\mathrm{X}=[\mathrm{OTf}]$} \\
\hline$\left[\mathrm{MeOC}_{2} \mathrm{~mm}_{\beta}\right.$ pip $]$ & 0.34 & 0.086 \\
\hline$\left[\mathrm{MeOC}_{2} \mathrm{OC}_{2} \mathrm{~mm}_{\beta} \mathrm{pip}\right]$ & 0.35 & 0.103 \\
\hline \multirow[t]{2}{*}{$\mathrm{MeOC}_{2}$ mpip] } & 0.75 & 0.176 \\
\hline & \multicolumn{2}{|c|}{$\mathrm{X}=\left[\mathrm{CF}_{3} \mathrm{CO}_{2}\right]$} \\
\hline$\left[\mathrm{MeOC}_{2} \mathrm{~mm}_{\beta}\right.$ pip $]$ & 0.37 & 0.088 \\
\hline$\left[\mathrm{MeOC}_{2} \mathrm{OC}_{2} \mathrm{~mm}_{\beta} \mathrm{pip}\right]$ & 0.44 & 0.124 \\
\hline$\left[\mathrm{MeOC}_{2}\right.$ mpip $]$ & 0.95 & 0.208 \\
\hline${ }^{a}$ Measured at $25.0^{\circ} \mathrm{C}$. & & \\
\hline
\end{tabular}

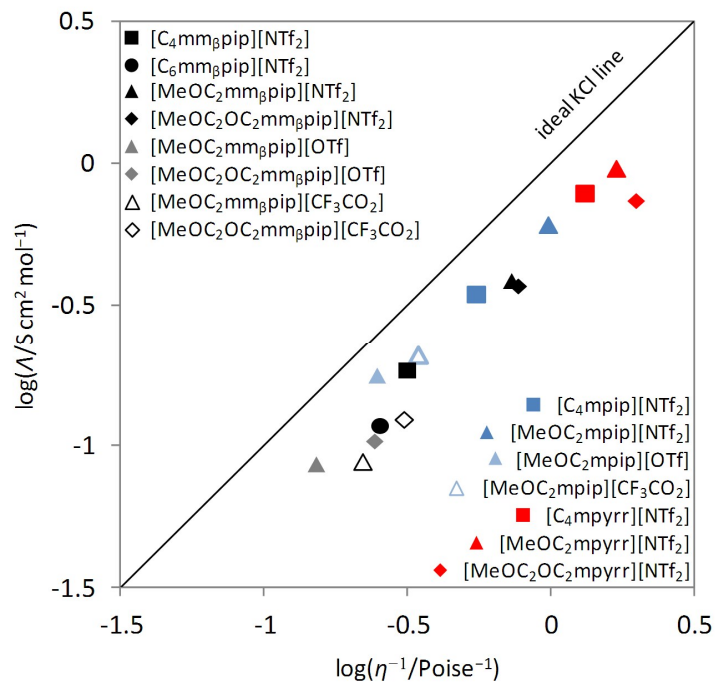

Fig. 14 Walden plot $\left(25^{\circ} \mathrm{C}\right)$ for the $\left[\mathrm{Rmm}_{\beta} \text { pip }\right]^{+},[\text {Rmpip }]^{+}$and $[\mathrm{Rmpyrr}]^{+}$ ionic liquids studied and for some previously reported analogues ([C $\left.\mathrm{C}_{4} \mathrm{mpip}\right]\left[\mathrm{NTf}_{2}\right],\left[\mathrm{MeOC}_{2} \mathrm{mpip}\right]\left[\mathrm{NTf}_{2}\right]$ and $\left[\mathrm{C}_{4} \mathrm{mpyrr}\right]\left[\mathrm{NTf}_{2}\right]$, data from reference ${ }^{30}$ ).

The cation ring type further affects conductivities to noticeable extents, as shown for the specific case of some selected $\left[\mathrm{NTf}_{2}\right]^{-}$ ${ }_{65}$ ionic liquids in the earlier related communication. ${ }^{25}$ Data presented in this paper (Table 5) show that the previously observed trend is also found for analogous $[\mathrm{OTf}]^{-}$or $\left[\mathrm{CF}_{3} \mathrm{CO}_{2}\right]^{-}$ salts. Thus, by comparing different anions or cationic cores (see 
Fig. 15), two trends are noted. First, conductivities are similar for ionic liquids based on the isomeric cations $\left[\mathrm{Rmm}_{\beta} \mathrm{pip}\right]^{+}$and $\left[\mathrm{Rmazp}^{+}\right.$; for example, $\left[\mathrm{MeOC}_{2} \mathrm{~mm}_{\beta} \mathrm{pip}\right][\mathrm{OTf}]$ and $\left[\mathrm{MeOC}_{2}\right.$ mazp][OTf] exhibit very close values $(0.34$ and ${ }_{5} 0.33 \mathrm{~ms} \mathrm{~cm}^{-1}$ at $25^{\circ} \mathrm{C}$, respectively). Secondly, ionic conductivity increases as the ring size decreases, i.e. they are higher for [Rmpip]X than for their seven-member ring analogues, [Rmazp]X $\left(\mathrm{X}=[\mathrm{OTf}]^{-}\right.$or $\left.\left[\mathrm{CF}_{3} \mathrm{CO}_{2}\right]^{-}\right)$. This confirms the more general trend found for $\left[\mathrm{NTf}_{2}\right]^{-}$ionic liquids, where reduction of 10 cation ring size from seven through to five members causes a steady increase in conductivities. ${ }^{25}$

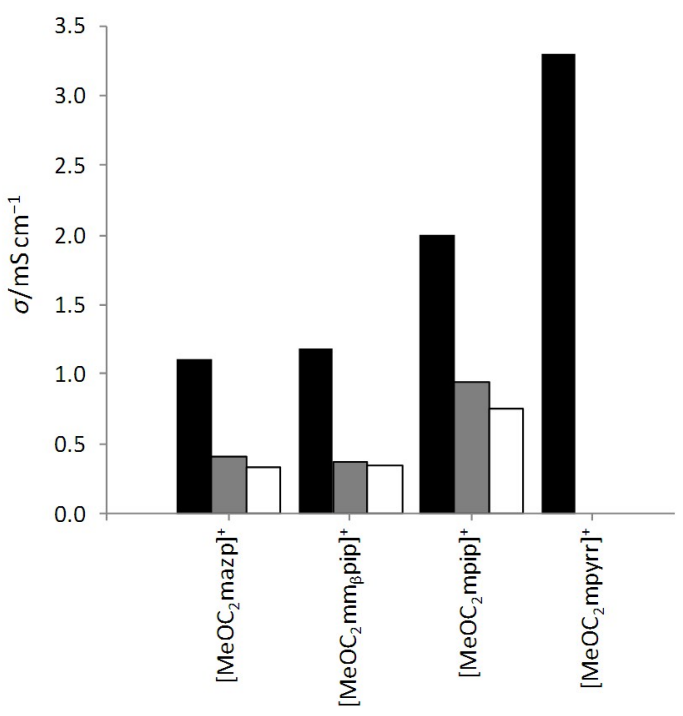

Fig. 15 Conductivities $\left(25^{\circ} \mathrm{C}\right.$ ) for $\left[\mathrm{NTf}_{2}\right]^{-}$(black bars), $\left[\mathrm{CF}_{3} \mathrm{CO}_{2}\right]^{-}$(grey bars) and [OTf] $]^{-}$(white bars) ionic liquids having 2-methoxyethyl as side 15 chain on different cation cores. Data from the literature are included for

$\left[\mathrm{MeOC}_{2}\right.$ mpip $]\left[\mathrm{NTf}_{2}\right]\left(\right.$ ref. $^{30}$ ) and $\left[\mathrm{Rmazp}^{+}\right.$ionic liquids (ref. ${ }^{38}$ ).

\section{Electrochemical windows}

Ionic liquids based on alicyclic quaternary ammonium cations, a group which include the materials examined in this work, have 20 been widely considered as promising electrolytes for a plethora of applications. $^{13,21,75}$ This is due to their remarkable potential windows $(>5.0 \mathrm{~V})$, which exceed those of either aprotic organic solvents such as ethanenitrile or the widely used 1,3-dialkylimidazolium ionic liquids $(c a .5 .0 \mathrm{~V}) .^{76}$ This is mostly

${ }_{25}$ because of the higher cathodic limits of the aliphatic ammonium systems; for ionic liquids, the aromatic imidazolium core is much more readily reduced than azepanium, ${ }^{38}$ piperidinium $^{14,21,77}$ or pyrrolidinium $^{15,17}$ systems, which contain no vacant $\pi^{*}$ orbitals.

The oxidation and reduction potentials and the derived 30 electrochemical windows of the ionic liquids based on $\left[\mathrm{Rmm}_{\beta} \mathrm{pip}\right]^{+}$and $[\mathrm{Rmpip}]^{+}$cations are listed in Table 6 . These data are derived from cyclic voltammograms as recorded for the neat ionic liquids. In some cases, the potential limits were also measured from analogous analyses of solutions in ethanenitrile, 35 since the high viscosities of the pure ionic liquids made observations of the potential limits difficult (see Experimental section). This can be seen in the case of $\left[\mathrm{C}_{6} \mathrm{~mm}_{\beta} \mathrm{pip}\right]\left[\mathrm{NTf}_{2}\right]$ in Fig. 16, where sharper current changes are observed for the solution as compared to the neat material.
40 Table 6 Electrochemical windows $(\Delta E)$ specifying cathodic $\left(E_{\mathrm{c}}\right)$ and anodic limits $\left(E_{\mathrm{a}}\right)$ for the studied 3-methylpiperidinium and piperidinium room temperature ionic liquids $[\mathrm{Q}] \mathrm{X}$.

\begin{tabular}{lccc}
{$[\mathrm{Q}]$} & $\Delta E / \mathrm{V}^{a}$ & $E_{\mathrm{c}} / \mathrm{V}^{a}$ & $E_{\mathrm{a}} / \mathrm{V}^{a}$ \\
\hline & \multicolumn{3}{c}{$\mathrm{X}=\left[\mathrm{NTf}_{2}\right]$} \\
\cline { 2 - 4 }$\left[\mathrm{C}_{4} \mathrm{~mm}_{\beta}\right.$ pip $]$ & 6.25 & -3.00 \\
{$\left[\mathrm{C}_{6} \mathrm{~mm}_{\beta}\right.$ pip $]$} & $6.25^{b}$ & $-3.25^{b}$ & 3.25 \\
{$\left[\mathrm{MeOC}_{2} \mathrm{~mm}_{\beta}\right.$ pip $]$} & 6.00 & -3.00 & 3.00 \\
{$\left[\mathrm{MeOC}_{2} \mathrm{OC}_{2} \mathrm{~mm}_{\beta}\right.$ pip $]$} & 5.50 & -3.00 & 2.50 \\
& \multicolumn{3}{c}{$\mathrm{X}=[\mathrm{OTf}]$} \\
{$\left[\mathrm{MeOC}_{2} \mathrm{~mm}_{\beta}\right.$ pip $]$} & $5.50^{b}$ & $-3.00^{b}$ & $2.50^{b}$ \\
{$\left[\mathrm{MeOC}_{2} \mathrm{OC}_{2} \mathrm{~mm}_{\beta}\right.$ pip $]$} & $5.50^{b}$ & $-3.00^{b}$ & $2.50^{b}$ \\
{$\left[\mathrm{MeOC}_{2} \mathrm{mpip}\right]$} & $5.50^{b}$ & $-3.25^{b}$ & $2.25^{b}$ \\
& \multicolumn{3}{c}{$\mathrm{X}=\left[\mathrm{CF}_{3} \mathrm{CO}_{2}\right]$} \\
{$\left[\mathrm{MeOC}_{2} \mathrm{~mm}_{\beta}\right.$ pip $]$} & $5.25^{b}$ & $-3.00^{b}$ & $2.25^{b}$ \\
{$\left[\mathrm{MeOC}_{2} \mathrm{OC}_{2} \mathrm{~mm}\right.$} & $\left.5.50^{b} \mathrm{pip}\right]$ & $-3.00^{b}$ & $2.50^{b}$ \\
{$\left[\mathrm{MeOC}_{2} \mathrm{mpip}^{b}\right.$} & $5.25^{b}$ & $-3.00^{b}$ & $2.25^{b}$
\end{tabular}

${ }^{a}$ Recorded by cyclic voltammetry $v s$. $\mathrm{Ag}^{+} / \mathrm{Ag}$ using glassy carbon working electrodes of $3 \mathrm{~mm}$ diameter and $\mathrm{Pt}$ coil counter electrodes. ${ }_{45}{ }^{b}$ Also recorded for $0.1 \mathrm{M}$ solutions in ethanenitrile because of the high viscosity of the neat liquids.

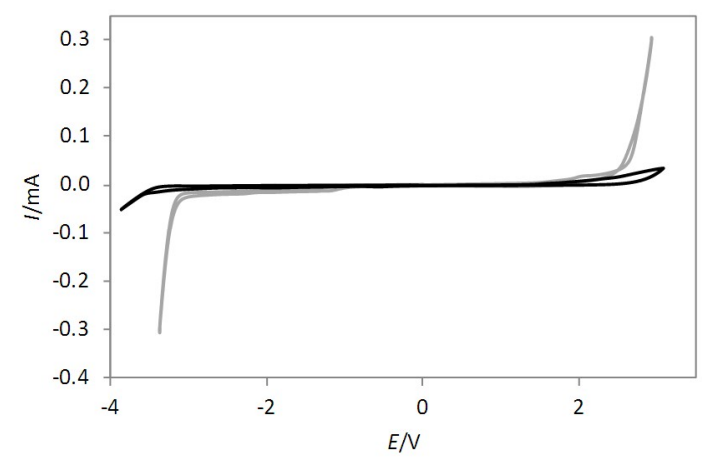

Fig. 16 Cyclic voltammograms $\left(25^{\circ} \mathrm{C}\right)$ of $\left[\mathrm{C}_{6} \mathrm{~mm}_{\beta}\right.$ pip $]\left[\mathrm{NTf}_{2}\right]$ as a neat ionic liquid (black) and in a $0.1 \mathrm{M}$ solution in ethanenitrile (grey), on glassy carbon electrodes $v s . \mathrm{Ag}^{+} / \mathrm{Ag}$ at $100 \mathrm{mV} \mathrm{s}^{-1}$.

Values of electrochemical windows in the range 5.25 to $6.25 \mathrm{~V}$ were obtained, which represent up to a $1.5 \mathrm{~V}$ advantage over the conventionally studied $\left[\mathrm{C}_{n} \mathrm{mim}\right]\left[\mathrm{NTf}_{2}\right]{ }^{20,}{ }^{78}$ This is the case for $\left[\mathrm{Rmm}_{\beta}\right.$ pip $]\left[\mathrm{NTf}_{2}\right]$ where $\mathrm{R}=$ alkyl, which exhibit the largest 55 values of potential windows $(>6 \mathrm{~V})$, similar to or slightly wider than those of analogous [Rmpip] ${ }^{+}$or $[\mathrm{Rmpyrr}]^{+}$salts $($e.g., $5.9 \mathrm{~V}$ for $\left[\mathrm{C}_{4}\right.$ mpyrr $\left.]\left[\mathrm{NTf}_{2}\right]\right),{ }^{17}$ considered as amongst the most electrochemically robust ionic liquids known to date. It should be noted that although $\left[\mathrm{NTf}_{2}\right]^{-}$may be cleaved at potentials within 60 the reported windows in low current processes, ${ }^{79}$ bulk oxidation and reduction processes are correctly represented by the potential limits shown in Table 6. Replacement of alkyl with alkoxyalkyl-containing side-chains in the cations results in a slight reduction of the potential ranges. On the other hand, [OTf] ${ }_{65}$ or $\left[\mathrm{CF}_{3} \mathrm{CO}_{2}\right]^{-}$ionic liquids are somewhat less electrochemically stable. These smaller electrochemical windows are due to lower oxidation potentials, e.g. 2.25 and $3.25 \mathrm{~V}$ for $\left[\mathrm{MeOC}_{2} \mathrm{~mm}_{\beta} \mathrm{pip}\right]\left[\mathrm{CF}_{3} \mathrm{CO}_{2}\right]$ and $\left[\mathrm{C}_{4} \mathrm{~mm}_{\beta}\right.$ pip $]\left[\mathrm{NTf}_{2}\right]$, respectively. However, cathodic limits are extremely negative $(\leq-3 \mathrm{~V})$ for all 70 the ionic liquids studied. The utility of such materials as electrolytes for energy storage devices might benefit from this, as recently suggested for lithium-ion batteries and capacitors. ${ }^{80}$ 


\section{Conclusions}

The asymmetric 3-methylpiperdinium cationic core has been shown to be a good constituent of room temperature ionic liquids, which can be prepared by classical double $\mathrm{N}$-alkylations of 5 3-methylpiperidine and, where desired, further anion metathesis. The resulting salts are diastereomeric mixtures containing all of the four possible cation isomers. Probably because of this, the tendency to crystallise is considerably smaller for $\left[\mathrm{Rmm}_{\beta} \text { pip }\right]^{+}$ salts as compared to either isomeric seven-member [Rmazp $]^{+}$ 10 azepanium or non- $C$-substituted $[\text { Rmpip }]^{+}$analogues. Crystallisation events were neither observed for any $\left[\mathrm{Rmm}_{\beta} \mathrm{pip}\right]\left[\mathrm{NTf}_{2}\right]$ nor even for the halide salt $\left[\mathrm{MeOC}_{2} \mathrm{OC}_{2} \mathrm{~mm}_{\beta}\right.$ pip]I $\left(T_{\mathrm{g}}=-46^{\circ} \mathrm{C}\right)$. In addition to their low liquid limits, they display wide electrochemical windows (5.25${ }_{15} 6.25 \mathrm{~V} v s$. glassy carbon). Therefore, 3-methylpiperidinium ionic liquids may be suitably included in electrolytes for low temperature applications.

Several examples of [Rmpip $]^{+}$and $[\text {Rmpyrr }]^{+}$salts presented here, together with $[\mathrm{Rmazp}]^{+}$analogues reported in previous 20 related papers, ${ }^{25}, 38$ complement a large family of alicyclic ammonium salts with different anions, cation ring sizes, or side chains. Systematic comparison of their physical properties, as graphically illustrated here, leads to well defined patterns:

(i) Ether-linked $N$-side chains on the cation cause decreases in 25 melting points (or totally frustrate crystallisation), decreases in viscosity, and increases in conductivity of the ionic liquids, as compared to their $N$-alkyl counterparts; this may have a connection with the bent comformations of ether-linked chains found in crystal structures, as opposed to the most often occurring 30 all-trans alkyls, as found in many analogous crystal structures.

(ii) Density, fluidity and ionic conductivity increase with decreasing ring size in the azepanium $>$ piperidinium $>$ pyrrolidinium cationic order.

(iii) Asymmetric introduction of a methyl group on $\mathrm{C}^{3}$ in 35 piperidinium results in $\left(\left[\mathrm{Rmm}_{\beta} \mathrm{pip}\right]^{+}\right)$ionic liquids with lower density and ionic conductivity and higher viscosity as compared to their non-carbon-substituted ([Rmpip $]^{+}$) analogues.

(iv) As compared to azepanium, their isomeric asymmetric 3-methylpiperidinium ionic liquids show, in addition to the lack 40 of crystallisation tendency, slightly lower viscositites, lower densities, and similar conductivities.

The large amount of 3-methylpiperidinium, azepanium, piperidinium, and pyrrolidinium ionic liquids presented herein, and in related publications, present excellent electrochemical ${ }_{45}$ robustness, especially under reductive conditions. Their physical properties can be finely modified by carefully adjusting structure, as seen in the trends and patterns reported throughout this manuscript. Indeed, this is one of the basic philosophies of ionic liquid chemistry - custom design. In summary, such ionic liquids 50 enrich the portfolio of promising electrolytes for demanding devices such as lithium batteries or supercapacitors.

\section{Acknowledgments}

We would like to acknowledge the EPSRC NCS in Southampton for the single crystal X-ray diffraction data collection and ${ }_{55}$ INVISTA Intermediates for funding.

\section{Notes and references}

${ }^{a}$ The QUILL Research Centre, School of Chemistry and Chemical Engineering, The Queen's University of Belfast, Stranmillis Road, Belfast BT9 5AG, United Kingdom.

${ }_{60}{ }^{b}$ INVISTA Intermediates, PO Box 401, Wilton, Redcar TS10 4XY, United Kingdom.

${ }^{c}$ Current addreess: Instituto de Tecnología Química (UPV-CSIC),

Universitat Politècnica de València, Avinguda dels Tarongers, 46022,

Valencia, Spain.E-mail: a.puga@csic.es.

$65 \dagger$ Electronic Supplementary Information (ESI) available: NMR, density and viscosity data tables. See DOI: 10.1039/b000000x/

1 C. Mikolajczak, M. Kahn, K. White and R. T. Long, Lithium-ion Batteries Hazard and Use Assessment, Springer, New York, 2012

702 N. S. Choi, Z. H. Chen, S. A. Freunberger, X. L. Ji, Y. K. Sun, K. Amine, G. Yushin, L. F. Nazar, J. Cho and P. G. Bruce, Angew. Chem. Int. Ed., 2012, 51, 9994-10024; H. B. Xing, C. Liao, Q. W. Yang, G. M. Veith, B. K. Guo, X. G. Sun, Q. L. Ren, Y. S. Hu and S. Dai, Angew. Chem. Int. Ed., 2014, 53, 2099-2103.

753 K. Ozawa, ed., Lithium Ion Rechargeable Batteries, Wiley-VCH, Weinheim, 2009.

4 W. A. van Schalkwijk and B. Scrosati, eds., Advances in Lithium-Ion Batteries, Kluwer Academic/Plenum Publishers, New York, 2002.

5 J. B. Goodenough, H. Abruna and M. Buchanan, Basic Research Needs

${ }_{80}$ For Electrical Energy Storage: Report of the Basic Energy Sciences Workshop For Electrical Energy Storage, 2007.

6 M. Kar, T. J. Simons, M. Forsyth and D. R. MacFarlane, Phys. Chem. Chem. Phys., 2014, 16, 18658-18674.

7 M. Balaish, A. Kraytsberg and Y. Ein-Eli, Phys. Chem. Chem. Phys., 2014, 16, 2801-2822; H. Ohno, ed., Electrochemical Aspects of Ionic Liquids, Wiley-Interscience, Hoboken, 2005; P. Hapiot and C. Lagrost, Chem. Rev., 2008, 108, 2238-2264; F. Endres and S. Z. El Abedin, Phys. Chem. Chem. Phys., 2006, 8, 2101-2116.

8 M. Armand, F. Endres, D. R. MacFarlane, H. Ohno and B. Scrosati, Nat. Mater., 2009, 8, 621-629.

9 A. Lewandowski and A. Świderska-Mocek, J. Power Sources, 2009, 194, 601-609.

10 M. C. Buzzeo, R. G. Evans and R. G. Compton, ChemPhysChem, 2004, 5, 1106-1120.

9511 D. R. MacFarlane and K. R. Seddon, Aust. J. Chem., 2007, 60, 3-5.

12 M. C. Buzzeo, C. Hardacre and R. G. Compton, ChemPhysChem, 2006, 7, 176-180.

13 D. Teramoto, R. Yokoyama, H. Kagawa, T. Sada and N. Ogata, in Molten Salts and Ionic Liquids: Never the Twain?, eds. M. Gaune-

100 Escard and K. R. Seddon, John Wiley \& Sons, Inc., Hoboken, 2010, pp. 367-388.

14 H. Matsumoto, H. Sakaebe and K. Tatsumi, J. Power Sources, 2005, 146, $45-50$.

15 E. I. Rogers, B. Sljukic, C. Hardacre and R. G. Compton, J. Chem. 105 Eng. Data, 2009, 54, 2049-2053.

16 J. Sun, M. Forsyth and D. R. MacFarlane, J. Phys. Chem. B, 1998, 102, 8858-8864; S. Pohlmann, T. Olyschläger, P. Goodrich, J. A. Vicente, J. Jacquemin and A. Balducci, Electrochim. Acta, 2015, 153, 426-432.

11017 D. R. MacFarlane, P. Meakin, J. Sun, N. Amini and M. Forsyth, $J$. Phys. Chem. B, 1999, 103, 4164-4170.

18 J. S. Wilkes and C. L. Hussey, Selection of Cations for Ambient Temperature Chloroaluminate Molten Salts Using MNDO Molecular Orbital Calculations, Frank J. Seiler Research Laboratory Technical Report 1982.

19 P. C. Trulove and R. A. Mantz, in Ionic Liquids in Synthesis, eds. P. Wasserscheid and T. Welton, Wiley-VCH, Weinheim, $2^{\text {nd }}$ edn., 2008, pp. 141-174.

20 A. M. O'Mahony, D. S. Silvester, L. Aldous, C. Hardacre and R. G. 120 Compton, J. Chem. Eng. Data, 2008, 53, 2884-2891.

21 J. Jin, H. H. Li, J. P. Wei, X. K. Bian, Z. Zhou and J. Yan, Electrochem. Commun., 2009, 11, 1500-1503.

22 P. C. Howlett, D. R. MacFarlane and A. F. Hollenkamp, Electrochem. Solid State Lett., 2004, 7, A97-A101; H. Sakaebe, H. Matsumoto and K. Tatsumi, Electrochim. Acta, 2007, 53, 1048-1054.

23 T. Abdallah, D. Lemordant and B. Claude-Montigny, J. Power Sources, 2012, 201, 353-359. 
24 M. Montanino, M. Moreno, M. Carewska, G. Maresca, E. Simonetti, R. Lo Presti, F. Alessandrini and G. B. Appetecchi, J. Power Sources, 2014, 269, 608-615; Y. Lu, K. Korf, Y. Kambe, Z. Tu and L. A. Archer, Angew. Chem. Int. Ed., 2014, 53, 488-492.

525 T. Belhocine, S. A. Forsyth, H. Q. N. Gunaratne, M. Nieuwenhuyzen, A. V. Puga, K. R. Seddon, G. Srinivasan and K. Whiston, Green Chem., 2011, 13, 59-63.

26 A. V. Puga, Chimica Oggi-Chemistry Today, 2013, 31, 12-16.

27 INVISTA $^{\text {TM }}$, DYTEK ${ }^{\mathbb{B}}$, http://dytek.invista.com/.

1028 R. W. Alder, J. G. E. Phillips, L. Huang and X. Huang, in Encyclopedia of Reagents for Organic Synthesis, John Wiley \& Sons, Ltd, 2001.

29 K. R. Seddon, T. Belhocine, A. V. Puga and K. Whiston, Low Viscosity Ionic Liquids, US Pat., 8345407 B2, 2013.

1530 Z. B. Zhou, H. Matsumoto and K. Tatsumi, Chem.-Eur. J., 2006, 12, 2196-2212.

31 T. Nishida, Y. Tashiro, M. Tomisaki, M. Yamamoto, K. Hirano, A. Nabeshima, H. Tokuda, K. Sato and T. Higono, Quaternary ammonium salt, electrolyte, and electrochemical device, Eur. Pat. 1642894 A1, 2006.

32 N. Honma and Y. Yamada, Quaternary Ammonium Salts, Eur. Pat., $1595863 \mathrm{~B} 1,2010$.

33 T. Umemoto and H. Koyama, Manufacture of room-temperature molten alicyclic ammonium salts, electrolytes containing them, and secondary lithium ion batteries, Jap. Pat., 206457A, 2006.

34 S. J. Coles and P. A. Gale, Chem. Sci., 2012, 3, 683-689.

35 G. M. Sheldrick, Acta Crystallogr. A, 2008, 64, 112-122.

36 O. V. Dolomanov, L. J. Bourhis, R. J. Gildea, J. A. K. Howard and H. Puschmann, J. Appl. Crystallogr., 2009, 42, 339-341.

3037 F. H. Allen, Acta Crystallogr. B, 2002, 58, 380-388; F. H. Allen and W. D. S. Motherwell, Acta Crystallogr. B, 2002, 58, 407-422.

38 T. Belhocine, S. A. Forsyth, H. Q. N. Gunaratne, M. Nieuwenhuyzen, P. Nockemann, A. V. Puga, K. R. Seddon, G. Srinivasan and K. Whiston, Green Chem., 2011, 13, 3137-3155.

3539 S. Forsyth, K. R. Seddon and K. Whiston, Ionic Liquids as Electrolytes, World Pat., 150842 A1, 2008.

40 G. Pandey, G. D. Reddy and G. Kumaraswamy, Tetrahedron, 1994, 50, 8185-8194; G. Pandey, G. Kumaraswamy and U. T. Bhalerao, Tetrahedron Lett., 1989, 30, 6059-6062.

4041 A. J. Carmichael, M. Deetlefs, M. J. Earle, U. Fröhlich and K. R. Seddon, in Ionic Liquids as Green Solvents: Progress and Prospects, eds. R. D. Rogers and K. R. Seddon, American Chemical Society, Washington D.C., 2003, pp. 14-31.

42 S. H. Fang, Z. X. Zhang, Y. D. Jin, L. Yang, S. Hirano, K. Tachibana and S. Katayama, J. Power Sources, 2011, 196, 5637-5644.

43 H. Shirota, A. M. Funston, J. F. Wishart and E. W. Castner, J. Chem. Phys., 2005, 122, \#184512; S. Ferrari, E. Quartarone, P. Mustarelli, A. Magistris, S. Protti, S. Lazzaroni, M. Fagnoni and A. Albini, $J$. Power Sources, 2009, 194, 45-50; G. B. Appetecchi, S. Scaccia, C.

50 Tizzani, F. Alessandrini and S. Passerini, J. Electrochem. Soc., 2006, 153, A1685-A1691.

44 I. Morishima, K. Yoshikawa and K. Okada, J. Am. Chem. Soc., 1976, 98, 3787-3793.

45 E. W. Garbisch and M. G. Griffith, J. Am. Chem. Soc., 1968, 90, 6543-6544.

46 R. K. Harris, Nuclear Magnetic Resonance Spectroscopy, Pitman Books Limited, London, 1983

47 E. L. Eliel, S. H. Wilen and M. P. Doyle, Basic Organic Stereochemistry, Wiley-Interscience, New York, 2001, pp. 436-491.

6048 F. Glorius, N. Spielkamp, S. Holle, R. Goddard and C. W. Lehmann, Angew. Chem. Int. Ed., 2004, 43, 2850-2852.

49 E. Matczak-Jon, V. Videnova-Adrabińska, A. Burzyńska, P. Kafarski and T. Lis, Chem.-Eur. J., 2005, 11, 2357-2372.

50 Q. Xu, Acta Crystallogr. E, 2012, 68, o1654.

${ }_{65} 51$ Q. Xu, Acta Crystallogr. E, 2012, 68, o1687.

52 Searches on the CSD for any piperidinium cation where the nitrogen atom is bonded to two non-metals and the ring carbon atoms are only bonded to hydrogen; 396 hits found.

53 Searches on the CSD for any pyrrolidinium cation where the nitrogen atom is bonded to two non-metals and the ring carbon atoms are only bonded to hydrogen; 212 hits found. For ring statistical analyses, an envelope conformation with a nitrogen flap (N-envelope) is here arbitrarily defined as that where the $\mathrm{C}_{\alpha}-\mathrm{C}_{\beta}-\mathrm{C}_{\beta}-\mathrm{C}_{\alpha}$ torsion angle is smaller than $5^{\circ}$ and all other ring torsions are larger than $5^{\circ} ; 328$ individual rings analysed, 97 being $\mathrm{N}$-envelopes.

54 R. W. Berg, M. Deetlefs, K. R. Seddon, I. Shim and J. M. Thompson, J. Phys. Chem. B, 2005, 109, 19018-19025.

55 A. Bondi, J. Phys. Chem., 1964, 68, 441-451.

56 J. A. van den Berg and K. R. Seddon, Cryst. Growth Des., 2003, 3, 643-661.

57 M. A. Henderson, J. Luo, A. Oliver and J. S. McIndoe, Organometallics, 2011, 30, 5471-5479.

58 P. M. Dean, J. M. Pringle and D. R. MacFarlane, Acta Crystallogr. E, 2008, 64, O637; G. Laus, G. Bentivoglio, V. Kahlenberg, U. J.

85 Griesser, H. Schottenberger and G. Nauer, Crystengcomm, 2008, 10, 748-752.

59 P. M. Dean, B. R. Clare, V. Armel, J. M. Pringle, C. M. Forsyth, M. Forsyth and D. R. MacFarlane, Aust. J. Chem., 2009, 62, 334-340.

60 Z. Fei, D. Zhao, R. Scopelliti and P. J. Dyson, Organometallics, 2004,

90 23, 1622-1628; G. Laus, A. Schwärzler, G. Bentivoglio, M. Hummel, V. Kablenberg, K. Wurst, E. Kristeva, J. Schütz, H. Kopacka, C. Kreutz, G. Bonn, Y. Andriyko, G. Nauer and H. Schottenberger, Z. Naturforsch. B, 2008, 63, 447-464; S. M. Murray, R. A. O'Brien, K. M. Mattson, C. Ceccarelli, R. E. Sykora, K. N. West and J. H. Davis, Angew. Chem. Int. Ed., 2010, 49, 27552758; J. Dupont, P. A. Z. Suarez, R. F. De Souza, R. A. Burrow and J.-P. Kintzinger, Chem.-Eur. J., 2000, 6, 2377-2381; O. Stenzel, H. G. Raubenheimer and C. Esterhuysen, J. Chem. Soc., Dalton Trans., 2002, 1132-1138; M. Niehues, G. Kehr, G. Erker, B. Wibbeling, R.

100 Fröhlich, O. Blacque and H. Berke, J. Organomet. Chem., 2002, 663, 192-203.

61 A. J. Arduengo, H. V. R. Dias, R. L. Harlow and M. Kline, J. Am. Chem. Soc., 1992, 114, 5530-5534; S. Parsons, D. Sanders, A. Mount, A. Parsons and R. Johnstone, personal communication; G. J. Reiss, personal communication; S. Saha, S. Hayashi, A. Kobayashi and H. Hamaguchi, Chem. Lett., 2003, 32, 740-741; J. Kärkkäinen, J. Asikkala, R. S. Laitinen and M. K. Lajunen, Z. Naturforsch. B, 2004, 59, 763-770.

62 J. D. Holbrey, W. M. Reichert, M. Nieuwenhuyzen, S. Johnston, K. R. Seddon and R. D. Rogers, Chem. Commun., 2003, 1636-1637.

63 Y. S. Vygodskii, E. I. Lozinskaya, A. S. Shaplov, K. A. Lyssenko, M. Y. Antipin and Y. G. Urman, Polymer, 2004, 45, 5031-5045; D. G. Golovanov, K. A. Lyssenko, Y. S. Vygodskii, E. I. Lozinskaya, A. S. Shaplov and M. Y. Antipin, Russ. Chem. Bull., 2006, 55, 1989-1999; M. Kawahata, T. Endo, H. Seki, K. Nishikawa and K. Yamaguchi, Chem. Lett., 2009, 38, 1136-1137; R. Ozawa, S. Hayashi, S. Saha, A. Kobayashi and H. Hamaguchi, Chem. Lett., 2003, 32, 948-949; A. Elaiwi, P. B. Hitchcock, K. R. Seddon, N. Srinivasan, Y. M. Tan, T. Welton and J. A. Zora, J. Chem. Soc., Dalton Trans., 1995, 34673472 .

64 T. Y. Wu, S. G. Su, K. F. Lin, Y. C. Lin, H. P. Wang, M. W. Lin, S T. Gung and I. W. Sun, Electrochim. Acta, 2011, 56, 7278-7287.

65 F. F. C. Bazito, Y. Kawano and R. M. Torresi, Electrochim. Acta, 2007, 52, 6427-6437.

12566 D. R. MacFarlane, J. Sun, J. Golding, P. Meakin and M. Forsyth, Electrochim. Acta, 2000, 45, 1271-1278; H. Tokuda, S. Tsuzuki, M. Susan, K. Hayamizu and M. Watanabe, J. Phys. Chem. B, 2006, 110, 19593-19600; J. Salminen, N. Papaiconomou, R. A. Kumara, J. M. Lee, J. Kerr, J. Newman and J. M. Prausnitz, Fluid Phase Equilib., 2007, 261, 421-426; M. Furlani, I. Albinsson, B. E. Mellander, G. B. Appetecchi and S. Passerini, Electrochim. Acta, 2011, 57, 220-227; H. Jin, B. O'Hare, J. Dong, S. Arzhantsev, G. A. Baker, J. F. Wishart, A. J. Benesi and M. Maroncelli, J. Phys. Chem. B, 2008, 112, 81-92.

67 F. Heym, B. J. M. Etzold, C. Kern and A. Jess, Phys. Chem. Chem. Phys., 2010, 12, 12089-12100.

68 D. R. Lide, ed., CRC Handbook of Chemistry and Physics, CRC Press, Boca Raton, 1999.

69 S. Bulut, P. Eiden, W. Beichel, J. M. Slattery, T. F. Beyersdorff, T. J. S. Schubert and I. Krossing, ChemPhysChem, 2011, 12, 2296-2310

14070 Z. J. Chen, T. Xue and J. M. Lee, RSC Adv., 2012, 2, 10564-10574; S. K. Tang, G. A. Baker and H. Zhao, Chem. Soc. Rev., 2012, 41, 4030-4066.

71 A. A. Fannin, D. A. Floreani, L. A. King, J. S. Landers, B. J. Piersma, D. J. Stech, R. L. Vaughn, J. S. Wilkes and J. L. Williams, J. Phys. Chem., 1984, 88, 2614-2621. 
72 G. Tamman and W. Z. Hesse, Z. Anorg. Allg. Chem., 1926, 156, $245-$ 257.

73 M. J. Monteiro, F. F. Camilo, M. C. C. Ribeiro and R. M. Torresi, J. Phys. Chem. B, 2010, 114, 12488-12494.

574 W. Xu, E. I. Cooper and C. A. Angell, J. Phys. Chem. B, 2003, 107, 6170-6178; C. A. Angell, N. Byrne and J. P. Belieres, Acc. Chem. Res., 2007, 40, 1228-1236; K. J. Fraser, E. I. Izgorodina, M. Forsyth, J. L. Scott and D. R. MacFarlane, Chem. Commun., 2007, 3817-3819; D. R. MacFarlane, M. Forsyth, E. I. Izgorodina, A. P. 10 Abbott, G. Annat and K. Fraser, Phys. Chem. Chem. Phys., 2009, 11, $4962-4967$.

75 H. Sakaebe and H. Matsumoto, Electrochem. Commun., 2003, 5, 594 598.

76 A. J. Bard and L. R. Faulkner, Electrochemical Methods:

$15 \quad$ Fundamentals and Applications, Wiley, New York, 2nd edn., 2001; L. E. Barrosse-Antle, A. M. Bond, R. G. Compton, A. M. O'Mahony, E. I. Rogers and D. S. Silvester, Chem.-Asian J., 2010, 5, 202-230.

77 H. Matsumoto, H. Sakaebe, K. Tatsumi, M. Kikuta, E. Ishiko and M. Kono, J. Power Sources, 2006, 160, 1308-1313.

2078 P. Bonhôte, A. P. Dias, N. Papageorgiou, K. Kalyanasundaram and M. Grätzel, Inorg. Chem., 1996, 35, 1168-1178.

79 D. R. MacFarlane, J. M. Pringle, P. C. Howlett and M. Forsyth, Phys. Chem. Chem. Phys., 2010, 12, 1659-1669; P. C. Howlett, E. I. Izgorodina, M. Forsyth and D. R. MacFarlane, Z. Phys. Chem., 2006, 220, 1483-1498.

80 K. Ito and T. Itakura, Power Storage Device, Lithium-Ion Secondary Battery, Electric Double Layer Capacitor and Lithium-Ion Capacitor, US Pat., 0002349 A1, 2012. 